\title{
CHILD DEATH, GRIEF, AND THE COMMUNITY IN HIGH AND LATE MEDIEVAL ENGLAND
}

\author{
A Dissertation \\ presented to \\ the Faculty of the Graduate School \\ at the University of Missouri-Columbia \\ In Partial Fulfillment \\ of the Requirements for the Degree \\ Doctor of Philosophy \\ by \\ DANIELLE NICOLE GRIEGO \\ Dr. Lois Huneycutt, Dissertation Supervisor \\ JULY 2018
}


(C) Copyright by Danielle Griego 2018

All Rights Reserved 
The undersigned, appointed by the dean of the Office of Graduate Studies, have examined the thesis entitled

CHILD DEATH, GRIEF, AND THE COMMUNITY IN HIGH AND LATE MEDIEVAL ENGLAND

presented by Danielle Nicole Griego,

a candidate for the degree of doctor of philosophy

and hereby certify that, in their opinion, it is worthy of acceptance.

Professor Lois Huneycutt

Professor A. Mark Smith

Professor Rabia Gregory

Professor John Frymire

Professor Michelle Morris 
For my parents, who have supported me throughout the entirety of my educational career. Thank you for all of your moral support. Thanks for standing by me when I wanted to be a Titanic historian, clipping out newspaper headings for my display, and the time I wanted to be the female version of Indiana Jones and then realized that an actual excavation required a trowel and sifter and not a fedora and bull whip. Thank you for encouraging me to travel overseas, igniting my passion for medieval history even further. You have been there in times of excitement and great stress and have helped me achieve many of my professional and academic goals. For all of this, I will be forever grateful. Also, thank you to Rupert and Steve, my fur babies. Rupert, you were my loyal companion, always by my side, protecting me during my first year at Mizzou. Steve, you are one of the sweetest dogs and make graduate school a lot more fun, even if you refuse to translate my Latin... 


\section{ACKNOWLEDGEMENTS}

I want to thank my advisor, Lois Huneycutt, for six years of guidance in the History graduate program. Thank you for aiding in the growth of my professional development through conferences and fellowship recommendations. Thank you for encouraging my love of the "depressing" fourteenth-century and being supportive of my interest in everything macabre. Without your guidance and support throughout the graduate process, this dissertation would not be possible.

I would also like to thank Rabia Gregory, who has gone above and beyond to help me on several of my projects. Thank you for reading dissertation and article drafts, and for giving me advice about academia, and life in general.

I also appreciate the support of my dissertation committee: Mark Smith, John Frymire, and Michelle Morris. Thank you for guiding me in classes, writing letters of recommendation on my behalf, and for agreeing to be on my committee. Also, thank you to other faculty who have offered to help me with course syllabi, who have written letters of recommendation, and have offered other valuable pedagogy advice: Lawrence Okamura, Theodore Koditschek, Ben Park, and Robert Collins. Thanks also to Johanna Kramer for keeping my love for Old English alive, and Nancy Taube and Patty Eggleston for helping me in the office throughout the years.

A big thanks to my friends and colleagues in medieval classes and weekly writing group sessions who have read countless drafts of my work, offered constructive feedback, and have offered ideas and book recommendations crucial to this project: Joe Genens, Alexis Miller, Heather Thornton McRae, Nina Verbanaz, Autumn Dolan, Colby Turberville, Chris Paolella, Eric Scott, Tanner Deeds, Amanda Kenney, Katelynn 
Robinson, and Doug Butler. Also, thanks to those in the department that have helped with writing and given moral support: Sarah Lirley McCune, Caitlin Lawrence, Mary Beth Brown, and Brandon Flint. Thank you also to my friends outside of the department for unconditional moral support throughout my education: Gabe Gabaldon, Elaine Obruca, Denise Gabaldon, Katie Carillo, Steph Servantes, Kristen Baca, Rebecca Benson, Kirk Gandy, and the Mizzou Swing Dance family.

This dissertation would also not be possible without the financial support of the Medieval Academy of America, Richard III Society, the University of Missouri Office of Research and Graduate Studies, and the University of Missouri History Department. In addition, thank you to all the librarians, archivists, museum curators, both at the University of Missouri and overseas, that helped with my research. Special thanks to Rosemarie Tiffen and St. Margaret's Church for allowing me to view and photograph the chrisom brass of Thomas Greville. Thanks also to Hazel Forsyth at the Museum of London and the curators at the Archaeology and Anthropology Museum at Downing College, Cambridge. 


\section{TABLE OF CONTENTS}

ACKNOWLEDGEMENTS

.ii

LIST OF

IMAGES. iv

INTRODUCTION: Examining Child Death and

Emotion. 1

CHAPTER ONE: "Death is Hiding Around a Dark Corner": The Dangers of Medieval

Childhood. .37

CHAPTER TWO: "I Should Have, But I Was Blind”: Displays of Maternal Grief. .72

CHAPTER THREE: "I Beg You Father, Do Not Mourn For Me”: Displays of Paternal Grief. 103

CHAPTER FOUR: "Neighbors Ran to the Sound of Their Strange Cries": Community Responses to Child

Death.....

CONCLUSION 175

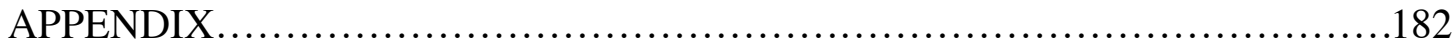

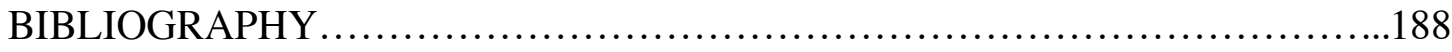

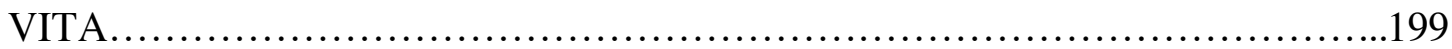




\section{List of Images:}

1. Fifteenth-century chrisom brass of Thomas Greville from St. Margaret's Church, Stanford rivers, Essex. 


\section{Introduction \\ Examining Medieval Child Death and Emotion}

William of Canterbury, one of the authors of the Thomas Becket miracle collection, reports in a twelfth-century miracle that an eight-year-old boy named Phillip was looking at rocks by a lake located in the county of Cheshire, when he slipped and was overtaken by the water (aquis obrutus est). When he did not return home, his father, Hugh Scot, searched for him everywhere in the village and found his body submerged in the lake. Hugh was sighing and groaning (suspiriis et gemitu) after extracting him from the water, and when Phillip's mother heard about his death, she indulged in tears and wailing (lacrymis indulget et plactui).${ }^{1}$ Rather than preparing the boy's corpse for a funeral, his parents attempted to revive him by suspending him by his feet in order to drain the liquid from his body, and when that did not work, by giving him holy water associated with Thomas Becket (aqua sancti Thome). According to William of Canterbury, because of the devotion of the parents (devotio parentum) and divine intervention, Phillip began to show signs of life, making his father leap forth (exsiliente) from his seat with excitement. ${ }^{2}$

In the Spring of 2015, I read the account about Phillip from Cheshire in the Thomas Becket miracle collection while searching for descriptions of medieval mortality for a conference paper. I was struck by the poignancy of the account, specifically by the

\footnotetext{
${ }^{1}$ Gemitu can also be translated as "moaning," according to the Oxford Latin Dictionary. ${ }^{2}$ William of Canterbury, Materials for the History of Thomas Becket, Archbishop of Canterbury, Canonized by Pope Alexander III., A. D. 1173., ed. James Robertson, Vol. 1 (London: Eyre and Spottiswoode, 1875), 201.
} 
imagery of Phillip's father and mother seeing their son's lifeless body sprawled on the ground, and of their refusal to accept his death demonstrated by their desperate attempts to revive him. Not just English mothers and fathers, but whole communities would have witnessed alarming rates of child mortality in the Middle Ages, a concept which is somewhat foreign to our modern minds. Today, the heartbreaking news about child death, in most cases, is viewed as "unexpected" or "rare." However, the medieval corpus reflects the grim reality that child death was common. Children perished from complications during birth, illness, foul play, and from infortunia, or accidental deaths that occurred around the household and community. Death rates were only heightened with the onset of the Black Death and episodes of famine in the fourteenth century. The amount of emotional trauma brought on by child death is incomprehensible, which brings me to my next observation about the excerpt in the previous paragraph. Another aspect of the miracle story that caught my eye was the emotion portrayed within the account.

William of Canterbury clearly depicts the grief of Phillip's parents over his death, both by showing their persistent attempts to resuscitate him and by using emotional dialogue to describe their feelings after they discovered his body. Phillip's father sighs and groans as he lays his son's body on the ground. His mother weeps and cries out over the devastation of the loss. These two different forms of emotional expression inspired this project because of the following questions that they raised: Is grief associated with child death commonly depicted in miracle stories (and other medieval texts)? If so, is the language/imagery of grief found in the account about Phillip typical of grief descriptions? Do authors of miracle stories portray mothers and fathers as grieving child death differently, and if so, why? How do medieval writers depict non-relatives (i.e., members 
outside of the immediate family) as interacting with deceased children and grieving families?

Although much work is being done to better understand relationships among medieval children, their families, and communities, examinations of descriptions of responses, specifically the emotion of grief, to child death, and the implications of these descriptions, remains on the periphery of medieval scholarship. This dissertation provides a study of portrayals of grief in relation to child death in England from the twelfth until the fifteenth century. I explore two main themes. First, I analyze how parents are depicted as mourning deceased offspring. Second, I elucidate how other members of the community, such as neighbors or crowds gathered at a child death scene, are represented as dealing and interacting with deceased children and families undergoing the mourning process. I argue that authors of later medieval texts not only portrayed child death as affecting the immediate family, but also showed it as extending beyond the household, causing a ripple effect of concern into the wider community. Moreover, I argue that authors employed the emotion of grief associated with child death to put forth their expectations about parent-child bonds, childrearing, community unity, religious devotion, and gender-appropriate forms of mourning.

Authors regularly portrayed maternal grief as being outwardly expressed and immoderate. Women, such as Phillip's mother, often cried out in distress, alerting those around them that a tragedy had occurred. This type of depiction of grief not only highlighted the emotional bonds between women and their children, but also the guilt and sense of responsibility that women were expected to experience when they did not supervise their children properly or keep them from harm's way. Some authors put forth 
the latter message more bluntly than others. Mothers were not only supposed to be nurturing and follow the example of the Virgin Mary but were also expected to be largely in charge of child care. When they failed in their duties, authors used grief to showcase the negative side of motherhood. Similarly, grief was used to demonstrate the love a father had for his child.

Fathers also showed their despair for deceased offspring through tears; yet, when authors did apply the characteristics of outward grief to fathers, they did not attach blame to them for a child's death as they did with mothers or, for the most part, portray paternal grief as attracting crowds. In other cases, paternal grief was restrained and fathers turned to their faith for consolation. When paternal grief was immoderate, authors often painted these men in a more negative light because their excessive grief led them astray from religion. Immoderate grief could disorient someone, leading them to sin or turning them away from their faith altogether. They could also step out of their role of paterfamilias because excessive grief could be seen as feminine. While historians have disagreed about how much influence heads of households actually had over their families, the paterfamilias still would have been the figurehead of the household, helping keep the family intact, especially in times of crisis. Therefore, when they stepped out of these roles, at least according to religious authors, the household dynamics could crumble. Lastly, I argue that, while authors typically did not differentiate between gendered forms of grieving in accounts about community intervention associated with child death because they described community members as working together and grieving as a whole, they still used the idea of grief to put forth messages about community solidarity and child guardianship. Authors demonstrated that those who were not part of the 
immediate family were expected to protect one another, especially children, from harm. Parental grief or the grief of a child's caretaker often alerted community members to the fact that a child death had occurred and action to help the child (and parents/caretakers) needed to be taken. When communities felt helpless in times of crisis, authors depicted them as participating in the grieving process with relatives and caretakers of children. Community solidarity and concern for children is not only represented in miracle stories, but also in prayers for the safety of unborn children, legal texts that show communities working together to protect children from domestic hazards, such as communal wells, and in brass memorials on behalf of children that would have been erected in parish churches for communities to watch and pray over.

To substantiate my arguments, miracle stories, particularly those attributed to Thomas Becket, Thomas of Cantilupe, Wulfstan, and Henry VI, provide the foundation for the discussion because they contain numerous accounts of child deaths and familial/community responses to those deaths. I analyze medieval lyrics about Christ's death in Chapter Two, which centers on maternal displays of grief. The Brome Abraham and Isaac, as well as the Middle English poem, the Perle (henceforth, Pearl) will be discussed alongside miracle stories in Chapter Three, the chapter on paternal grief. By using a range of sources in these chapters, different in date and purpose, I demonstrate that a similar pattern of parental grief and community concern for children surfaces.

\section{HISTORIOGRAPHY}

Although scholarship centered on grief and child death is sparse, emotions of past cultures have been a recent concern amongst scholars. Barbara Rosenwein, in her article 
"Worrying about Emotions in History," revisits the historiography of emotion studies in order to dispute the idea that "historians have not treated the subject at all."33 She recognizes that the analysis of emotion in historical research has been mostly tangential, but argues that historians have always been talking about emotion, just not in the most productive way. For example, historians of the early twentieth century characterized premodern societies as having "primitive" emotions or assigned emotional characteristics to whole societies and periods, disregarding the nuances and fluidity of emotional expression in the past altogether.

One such scholar was the Dutch historian Johan Huizinga, who categorized the entirety of Middle Ages as a time of emotional extremes based on modern perceptions of “civilization.” In the very first chapter of classic work, Herfsttij der Middeleeuwen (1919), translated into English as The Waning of the Middle Ages (1924). In the 1996 edition, Rodney Payton and Ulrich Mammitzsch translated Huizinga's thoughts about the oscillating and volatile temperaments of Middle Ages:

When the world was half a thousand years younger all events had much sharper outlines than now. The distance between sadness and joy, between good and bad fortune, seemed to be much greater than for us; every experience had that degree of directness and absoluteness that joy and sadness still have in the mind of a child...There was less relief available for misfortune and for sickness; they came in a more fearful and more painful way. Sickness was contrasted more strongly with health. The cutting cold and the dreaded darkness of winter were more concrete evils. Honor and wealth were enjoyed more fervently and greedily

${ }^{3}$ Barbara Rosenwein, "Worrying about Emotions," The American Historical Review 107, no. 3 (2002): 821 . 
because they contrasted still more than now with lamentable poverty...In short, all things in life had about them something glitteringly and cruelly public. ${ }^{4}$

Huizinga viewed the period as "the childhood of man," an age when people expressed emotions in an infantile manner. Rosenwein and Riccardo Cristiani point out that the idea of a "primitive" age of emotions was common during Huizinga's time and that "The Middle Ages was the Western historians' equivalent of tribal cultures." ${ }^{\circ 5}$ In the passage above, Huizinga contends that fears about disease, poverty, and the volatile and public nature of medieval life in general gave way to impulsive emotional displays from people of the period. People who did not know how to restrain their emotions because they had not gone through the civilizing process. For the Dutch historian, a shift towards optimism and emotional restraint would not occur until the fifteenth century and would only "fully bloom during the eighteenth century."

Huizinga was not alone in his concept of emotional extremes. The German sociologist Norbert Elias in his work, The History of Manners and State Formation (1939), described the emotions of the Middle Ages, but this time through a Freudian lens. Elias, a refugee from Nazi Germany, wrote his work in England, but it made little impact upon initial publication. It was not until its re-publication in 1968 and translation into

\footnotetext{
${ }^{4}$ Johan Huizinga, The Autumn of the Middle Ages, trans. Rodney Payton and Ulrich Mammitzsch (Chicago: The University of Chicago Press, 1996), 1.

${ }^{5}$ Riccardo Cristiani and Barbara Rosenwein, What is the History of Emotions? (Cambridge: Polity Press, 2018), 27.

${ }^{6}$ Huizinga, The Autumn of the Middle Ages, trans. Rodney Payton and Ulrich Mammitzsch, 30-31.
} 
French and English in the 1970s that its influence began to spread. ${ }^{7}$ Of people and emotions in the medieval world Elias wrote:

People are wild, cruel, prone to violent outbreaks and abandoned to the joy of the moment. They can afford to be. There is little in their situation to compel them to impose restraint upon themselves. Little in their conditioning forces them to develop what might be called a strict and stable super-ego, as a function of dependence and compulsions stemming from others transformed into selfrestraints. ${ }^{8}$

Similar to Huizinga, Elias paints a picture of an emotionally turbulent Middle Ages. What Elias meant by "There is little in their situation to compel them to impose restraint upon themselves," is that medieval people did not have a sense of "state" to rein in their emotions or actions. In other words, they had free rein over their behavior because they had not yet gone through the civilizing process, which for Elias, would start with the rise of courtly culture and solidify in the seventeenth century, with the formation of the state under Louis XIV. ${ }^{9}$ Stephen Jaeger, in The Origins of Courtliness: Civilizing Trends and the Formation of Courtly Ideals (1985), would later refute this theory, and argue that courtly culture had its origin in the tenth and eleventh centuries with the courtier bishop. ${ }^{10}$

\footnotetext{
${ }^{7}$ Rosenwein, "Worrying about Emotions in History," 826.

${ }^{8}$ Norbert Elias, The History of Manners and State Formation, Vol. 1 of The Civilizing Process, trans. Edmund Jephcott (Oxford: Blackwell Publishers, 1994), 319.

${ }^{9}$ Elias, The History of Manners, trans. Edmund Jephcott, 324.

${ }^{10}$ Stephen Jaeger, The Origins of Courtliness: Civilizing Trends and the Formation of Courtly Ideals (Philadelphia: University of Pennsylvania Press, 1985).
} 
Interest in studies of emotion continued into the 1940s and beyond. In 1941, French historian and co-founder of the Annales School, Lucien Febvre, called for the study of emotions after reading Huizinga's work during the rise of Nazism. ${ }^{11}$ He believed that the mentalité, or cultural mindset, could be revealed through emotions and that unless emotions were studied thoroughly by historians, they "would erupt again and again." ${ }^{12}$ Febvre argued that emotions were created from the languages and ideas of humans but that they were "not part of civilized life, however essential they were to its existence."13 Huizinga's influence not only seeped into the minds of 1940s historians, but also psychological studies of emotion in the 1980s, specifically the work of Peter and Carol Stearns..$^{14}$

The emotions of medieval people have been reevaluated since the days of the Febvre's call to action in the 1940s. After the Second World War, an outpouring of historical demography projects forced historians of the 1960s and 70s to take a closer look at relationships, including emotional bonds, among members of the pre-modern

\footnotetext{
${ }^{11}$ Rosenwein and Cristiani, What is the History of Emotion?, 27.

${ }^{12}$ Rosenwein and Cristiani, What is the History of Emotion?, 28.

${ }^{13}$ Rosenwein, "Worrying about Emotions," 822-823.
}

${ }^{14}$ The Stearns' coined the term "Emotionology," and argued, like Huizinga and Elias, that people did not know how to practice emotional restraint until the modern era and that courtly love literature could not be studied to understand the emotional standards of a society because these sources fell under the category of intellectual history. Rosenwein points out that if this is true, then all pre-modern sources must be excluded under the discipline of "Emotionology." For more details about "Emotionology" see Rosenwein, "Worrying about Emotions," 824 and Rosenwein and Cristiani, What is the History of Emotion?, 29-34. 
European family. ${ }^{15}$ French medievalist Philippe Ariès in his Centuries of Childhood: A Social History of Family Life (1962), originally published as L'Enfant et la vie familial sous l'ancien régime (1960), sought to analyze the concept of "childhood" from the Middle Ages until modernity. He famously argued that medieval children "were mixed in with adults," because the concept of "childhood" as a stage in human development is a modern concept, a concept which only fully trickled down from the upper to lower classes during the nineteenth and twentieth centuries. Ariès concluded that people of the Middle Ages had lost sight of the notion of paideia. ${ }^{16}$ In turn, children who were weaned "went straight into the great community of men," which "loosened the emotional bond between parents and children." ${ }^{17} \mathrm{He}$ added the disclaimer that historians should not

\footnotetext{
${ }^{15}$ French demographer Louis Henry used statistical analysis from parish registers to reconstruct the population of France from the seventeenth until the nineteenth centuries. Through his analysis, he was able to learn more about birth and death rates, and marriages. Peter Laslett and Edward Wrigley co-founded the "Cambridge Group for the History of Population and Social Structure" in 1964. They used Henry's model and applied it to English parishes. The work of these demographers pushed boundaries. They not only encouraged historians to reconsider the composition of pre-modern people occupying a typical European household, but also the relationships between people within the familial unit.
}

${ }^{16}$ Paideia refers to the ancient Greek idea of educating and rearing children to become ideal members of the Greek polis.

${ }^{17}$ Philippe Ariès, Centuries of Childhood: A Social History of Family Life, trans. Robert Baldick (Toronto: Random House of Canada Limited, 1962), 128, 411. To reinforce his argument that children were viewed as mini adults as soon as they stopped nursing, Ariès points out that artwork of the Middle Ages did not convey children donning garb that distinguished them from adults, because children went straight from swaddling bands to being "dressed just like the other men and women of his class," 50, 129. Additionally, he explains that both adults and children had similar pastimes and that no religious festivals were held on behalf of children, except for seasonal pagan festivals, which ultimately declined in popularity because of Christianity, 71,125 . He contrasts these examples with changes he sees in the seventeenth and eighteenth centuries, the periods, he claims, that "childhood" was starting to be "discovered," albeit only by the upper classes of French society at first. According to Ariès, during this period, toys made specifically for children (e.g., the hobby-horse) are found, there is more of a focus on putto (i.e., the child portrait) 
mistake "childhood" with affection for children. ${ }^{18}$ That is to say, he did not mean to argue that parents were completely devoid of affection for their children. Parents still cared about offspring, but accepted the fact that they could, and probably would, die. In addition, the strong parent-child bonds that Ariès saw in the twentieth century were essentially non-existent because children were treated as (young) adults as soon as they could fend for themselves. Children under the age of seven, on the other hand, simply "did not count" as members of a community because it was uncertain whether they would survive childhood. ${ }^{19}$ Because survival rates were low, Ariès claims that, medieval families had several children, with the knowledge that only a few would survive. He cites a story from a seventeenth century Le Caquet de l'accouchèe, a French satire, about a mother with five children to make his point. A neighbor, standing by the bedside of the woman who had given birth, told her not to worry, because, before the children were old enough to really bother or annoy her, half would have perished. ${ }^{20}$

Lawrence Stone echoed some of Ariès' sentiments in his book about the earlymodern English family, The Family, Sex and Marriage in England, 1500-1800 (1977).

in artwork, and the ceremony of First Communion for children becomes widespread, 67, 126-127. Ariès completely disregards textual evidence, such as lullabies and riddles for children, that demonstrate bonds between parents and children, as well as the fact that "childhood" was recognized by medieval families. He also does not take into account rites of passage ceremonies, such as baptism and funeral processions, which indicate that even the youngest members of medieval societies were not considered social "others." Authors have since gone on to prove this in their scholarship, and this will be addressed shortly in the introduction.

${ }^{18}$ Ariès, Centuries of Childhood, trans. Robert Baldick, 128.

${ }^{19}$ Ariès, Centuries of Childhood, trans. Robert Baldick, 128, 411.

${ }^{20}$ Ariès, Centuries of Childhood, trans. Robert Baldick, 38. Ariès uses Afne Didron's "La Vie Humaine," Annales archéologiques 15 (1855): 413. 
He posited that medieval peasant families lacked the privacy of nuclear families in the modern era, a privacy needed in order to form affective bonds with one another. This lack of privacy was a result of the open lineage focus of the medieval household. In other words, there was more of a focus on kinship ties than nuclear bonds. Stone, like Ariès, also argued that, not only did that the open lineage family structure sever affective bonds, but also that emotions towards children were especially restrained because of the high rates of mortality of the period. He writes that "death was at the centre of life [especially in regards to children], as the cemetery was at the centre of the village." ${ }^{21}$ For this reason, "it was a folly to invest too much emotional capital in such ephemeral beings." ${ }^{22}$ Even from the sixteenth century until the early seventeenth centuries, says Stone, "very many fathers seem to have looked on their infant children with much the same degree of affection which men today bestow on domestic pets, like cats and dogs." ${ }^{23}$ A strong affective bond only came with a child's longevity. Otherwise, child death was met with indifference. $^{24}$

${ }^{21}$ Lawrence Stone, The Family, Sex and Marriage in England, 1500-1800 (New York: Harper \& Row Publishers, Inc., 1977), 67.

${ }^{22}$ Stone, The Family, 105.

${ }^{23}$ Stone, The Family, 105.

${ }^{24}$ Stone, The Family, 106, 267. Stone's main argument is that the institution of the family underwent a series of changes, regarding structure and relationships, from 1500-1800. In 1500 , there was the "open lineage family," where kinship and community in the upper classes took priority over the nuclear family. What is more, the high death tolls of the time left families feeling unsentimental towards each other. He states that the fear of being infected by plague "destroyed the bonds of family solidarity," 76 . Also, he posited that it took time for parents to form bonds with children. Thus, when they died young, bonds had not yet been formed. From 1530 until 1640, ties to kinship networks declined and there was a focus on the nuclear family, with the head of household at the center because of promotion of the patriarchy in religion. This eventually gave way to the 
Historians quickly dismantled the arguments of Ariès and Stone soon after they were published and proved that medieval people were not the callous, unsentimental beings that they were once made out to be. David Herlihy, in Medieval Households (1985), painted a picture of a medieval household where fathers ruled the roost and mothers invested their time into nurturing children. Both parents, according to Herlihy, had affective ties to children, even in times of epidemic..$^{25}$

Barbara Hanawalt's seminal work, The Ties That Bound: Peasant Families in Medieval England (1987), in particular reconsidered the peasant family of fourteenthand fifteenth-century England. Rather than portraying peasant life (or medieval life in general) as the "Bad Old Days," where families were "boorish, unsentimental, unsociable, gossipy creatures," Hanawalt demonstrated that medieval people had emotional bonds with one another, both within the immediate family and wider community. She asserts that families thrived on the nuclear, not open lineage, household system. This nuclear model was based on the "partnership" marriage, meaning that married couples worked together in order to keep the economy of the household running properly. The nuclear family also depended on additional layers of support from the wider community. ${ }^{26}$ Hanawalt's nuclear family was nurturing not only because people

"closed domesticated nuclear family." The home became increasingly private, people married for love, and families were more child-centered.

${ }^{25}$ David Herlihy, Medieval Households (Cambridge: Harvard University Press, 1985), 125-130.

${ }^{26}$ Barbara Hanawalt, The Ties That Bound: Peasant Families in Medieval England (Oxford: Oxford University Press, 1986), 8. Hanawalt also dispels the idea that medieval people lived in extremely dirty conditions, an idea that encouraged people to think of the Middle Ages as an unpleasant time. Archaeological evidence shows that, while humans and animals traveled in and out of the household on a daily basis, animals were often separated from living quarters, and families often swept and cleaned the inside of houses 
cared about one another, but also because emotional ties fostered an environment that allowed the family to flourish economically. ${ }^{27}$ In her work, Hanawalt also shows how the medieval corpus contains evidence of a variety of emotions. Medieval people displayed anger when fighting over village boundaries, concern for neighbors in need, fear when convicted of crimes, and love for one another, especially children, as evidenced in wills coroners' inquests, and recorded acts of charity. While Hanawalt's work has reshaped the image of the peasant household and much of her project centers on child death reports from coroners' inquests, she only mentions grief associated with child death.

Other historical research, specifically about medieval childhood, has continued the conversation about childhood and emotion. Shulamith Shahar's Childhood in the Middle Ages (1990), Ronald Finucane's The Rescue of the Innocents: Endangered Children in Medieval Miracles (1997), Eleanora Gordon’s “Accidents Among Medieval Children As Seen From the Miracles of Six English Saints and Martyrs" (1991), Nicholas Orme's Medieval Children (2001), and Amy Vines's, “Lullaby as Lament: Learning to Mourn in Middle English Nativity Lyrics" (2010), all demonstrate that communities had emotional attachments to children and often grieved over their deaths, even further dismantling the theories that "childhood" was not recognized in the pre-modern world and that children were considered social "others."

because of the constant traffic. Hanawalt does acknowledge that the level of cleanliness and hygiene would have still seemed much worse than modern standards, 37; See also commentary on Hanawalt's work in Katherine French et al., eds., The Ties that Bind: Essays in Medieval British History in Honor of Barbara Hanawalt (New York: Routledge, 2011), 199-200.

${ }^{27}$ Katherine French et al., eds., The Ties that Bind, 200. 
Orme's Medieval Children addresses topics such as childbirth, rites of passage for children, and education that children received from the eleventh until the sixteenth century. Several chapters are devoted to arguing against Ariès' theory that children were just small adults. Orme points to literature and archaeological evidence of the time to show that children wore distinct clothing, "had toys, chanted rhymes, played games, and read literature invented by themselves or designed especially for them." ${ }^{28}$ Moreover, he says, children were named, prior to baptism, after relatives and godparents, verifying that children were not only immediately assigned an identity within a particular community, but also that they were shown affection long before they reached an age where survival was more likely. ${ }^{29}$ Medieval Children also has a chapter on causes of child death in which grief is mentioned, albeit briefly. ${ }^{30}$ Orme suggests that evidence of grief may be seen in memorials erected and funeral processions held on behalf of children. He ends the section on child death with an important statement that directly contradicts Arìes' view of the effect of high mortality rates: "the fact that so many children died did not necessarily

\footnotetext{
${ }^{28}$ Nicholas Orme, Medieval Children (New Haven: Yale University Press, 2001), 10. For a more detailed discussion about garments made for children during different stages of the aging process in England see also Roberta Gilchrist, Medieval Life: Archaeology and The Life Course (Woodbridge: The Boydell Press, 2012), 68-98. Gilchrist reinforces the idea that children did have their own culture and that this culture can be seen through the material record, specifically through their "social skins" or clothing. Specific articles of clothing were made for children during different rites of passage, such as baptismal chrisom. Children wore different styles of clothing (and hairstyles) as they aged. Infants did not wear sewn clothing, but were wrapped in linen bands and were given knitted caps and booties made out of wool. Older children wore gowns with buckles, pins, and sometimes lacing. Hair style was also indicative of age/being part of a certain stage of life. Married women usually covered their heads with a headdress, whereas young female children wore their hair lose over their shoulders.

${ }^{29}$ Orme, Medieval Children, 35-43.

${ }^{30}$ Orme, Medieval Children, 93-128.
} 
lighten the pain of their loss for their parents." ${ }^{31}$ In other words, although medieval people were familiar with child death, and death in general, it did not mean that they became inhuman, devoid of emotion and avoided investing emotional capital into their offspring.

Shahar echoes Orme's beliefs in Childhood in the Middle Ages. The format of her book is similar to Orme's, with sections on childbirth, education, and causes of death. She discusses emotion associated with child death in more detail. In reference to high child mortality rates, she states,

It has been postulated that, since people died in their thousands in epidemics, fear of death was blunted and the grief of survivors was more diffuse and less personal in the general atmosphere of mourning. One can only ask whether it is easier today for people who lose their loved ones in a war or an earthquake to bear their grief than for those who lose someone through natural causes or accidents. There is no clearcut answer. The high number of deaths in plagues could have intensified the fear of death, and it is by no means clear that those who lost their children were comforted by the fact that the children of others had also died. Death was common and familiar, and, due to the high birth-rate and high infant mortality, parents could not grant each of their children the amount of attention devoted by modern western parents or mourn their children's demise for very long. But, in view of the extant evidence, it cannot be said that the death of a child was an event lacking emotional impact. ${ }^{32}$

Shahar and Orme make the good point that, even though child death was common in the medieval world, people were human, with real emotions and attachments to their

\footnotetext{
${ }^{31}$ Orme, Medieval Children, 121, 123.

${ }^{32}$ Shulamith Shahar, Childhood in the Middle Ages (London: Routledge, 1990), 155.
} 
children, a concept that historians may unconsciously gloss over because we are so far removed in time from the people that we study ${ }^{33}$ Shahar also makes the good point that constant death might not have made people numb to it, but rather made them more prone to grief because of the fear that they or their loved ones could perish at any time.

Amy Vines, Ronald Finucane, and Eleanora Gordon push the boundary on the discussion of emotions towards children with their works. Vines' article "Lullaby as Lament: Learning to Mourn in Middle English Nativity Lyrics," looks solely at Middle English lullabies compiled in the fourteenth and fifteenth centuries to understand the mourning process of mothers in England. After analyzing several lullabies that describe the Virgin Mary thinking about the suffering and death of Christ on the Cross, Vines underscores two ideas. Her first argument is that Mary's reaction to Christ's death is a reflection of how medieval mothers grieved over children in reality. Therefore, according to Vines, lullabies can give us direct insight into concepts of motherhood and the grieving process in late-medieval England. The second point she makes is that lullabies served as outlets for grieving mothers. In other words, lullabies were used to comfort mothers facing child death more than they were used to soothe children. The lyrics that were used in these songs were poignant reminders that children could die at any time, but they also

\footnotetext{
${ }^{33}$ Other important works on medieval childhood that touch on parent-child bonds or emotion towards children include: John Boswell, The Kindness of Strangers: The Abandonment of Children in Western Europe from Late Antiquity to the Renaissance (Chicago: The University of Chicago Press, 1988). Barbara Hanawalt, Growing Up in London: The Experience of Childhood in History (New York: Oxford University Press, 1993), Sally Crawford, Childhood in Anglo-Saxon England (2000) Jeremy Goldberg, Youth in the Middle Ages (2004), Sara Butler, "A Case of Indifference: Child Murder in Later Medieval England," Journal of Women's History 19, no. 4 (2007): 59-82, and Christian Laes and Katariina Mustakallio, eds., The Dark Side of Childhood in Late Antiquity and the Middle Ages (Oxford: Oxbow Books, 2011).
} 
encouraged mothers to be strong, like Mary, the paragon of motherhood, when their offspring perished..$^{34}$

In contrast to Vines, Finucane's The Rescue of the Innocents: Endangered Children in Medieval Miracles centers on 600 accounts of child death and near-death experiences in posthumous miracle stories from England and the Continent, which date between the twelfth until the fifteenth century. Finucane's main goal is to describe different ailments and injuries that afflicted children of the Middle Ages and holy intercessors, such as Saint Thomas Becket of Canterbury, who were called upon to cure or resuscitate them. Most importantly, for the purposes of this project, Finucane devotes an entire chapter to grief and child death. He demonstrates that there are many examples of parents in miracle stories pleading for divine help to save their children. Finucane also touches on the involvement of the wider community in instances of child death. He suggests, albeit briefly, that community members played a critical role in attempting to help children in danger. ${ }^{35}$ Eleanora Gordon in her article "Accidents Among Medieval Children as Seen from the Miracles of Six English Saints and Martyrs," follows in Finucane's lead. She examines miracle stories involving children in order to reconstruct the types of child illnesses and accidents. One section of the article addresses grief, both familial and communal, in child miracle stories. ${ }^{36}$ Vines, Finucane, and Gordon add to the

\footnotetext{
${ }^{34}$ Amy Vines, "Lullaby as Lament: Learning to Mourn in Middle English Nativity Lyrics," in Laments for the Lost in Medieval Literature, eds. Jane Tolmie and Jane Toswell (Turnhout: Brepolis, 2010), 200-201.

${ }^{35}$ Ronald Finucane, The Rescue of the Innocents: Endangered Children in Medieval Miracles (New York: St. Martin's Press, 1997), 148.

${ }^{36}$ Eleanora Gordon, "Accidents Among Medieval Children as Seen from the Miracles of Six English Saints and Martyrs," Medical History 35, no. 2 (1991): 145-163.
} 
conversation on grief by devoting whole sections and articles to the topic, something that is not usually seen in books about medieval childhood. They go beyond just confirming that child death made communities grieve, and show sources containing actual emotional expression. Nevertheless, the objective of these works still mainly lies on disproving Arìes' conclusions about relationships between children and their parents, rather than looking at patterns of emotional expression.

Over the last ten years, emotion, not necessarily in relation to child death has become more of a focus in the field. Carol Lansing, for instance, in Passion and Order: Restraint of Grief in the Medieval Italian Communes (2008) looks at perceptions of grief in thirteenth-century Italy. She argues that medieval people living in Italy believed that powerful grief could lead to sin and the loss of rational control and therefore it was viewed as a threat to peaceful community. ${ }^{37}$ The book, Emotions in the Household, 12001900 (2008), also grapples with a range of emotions. One essay in the book, by Anna Hansen, examines emotional bonds between children and their foster-parents in early Icelandic society. Hansen shows that foster-parents loved their children because they were willing to risk their lives for them and grieved when they died.$^{38}$ Other scholarship on emotion has focused on such topics as the tears of Margery Kempe and emotional expression within medieval Arthurian literature. ${ }^{39}$ Another historian's work that must be

\footnotetext{
${ }^{37}$ Carol Lansing, Passion and Order: Restraint of Grief in the Medieval Italian Communes (Ithaca: Cornell University Press, 2008), 7, 195.
}

${ }^{38}$ Anna Hansen, "Children and Their Foster-Parents in Early Icelandic Society," in Emotions in the Household, 1200-1900 ed. Susan Broomhall (Houndmills: Palgrave Macmillan, 2008).

${ }^{39}$ Kimberley Patton and John Hawley, eds., Holy Tears: Weeping in the Religious Imagination (Princeton: Princeton University Press, 2005). 
mentioned is that of Rosenwein, who was introduced at the beginning of this section. Although her work does not center specifically on emotion and children, her proposed approach to studying past emotions has affected historical research, including my own. Rosenwein has written various articles tracing the history of emotions and has employed her new approach to the study in her books, Emotional Communities in the Early Middle Ages (2006) and Generations of Feeling: A History of Emotions, 600-1700 (2016). She contends that medieval historians are interested in "utterances and gestures of emotion" and use them in projects to make summaries and quotations more colorful. ${ }^{40}$ When using this method, Rosenwein explains, scholars only go as far as underscoring emotions in historical texts to make passages appear livelier, but they do not go any further than that. She calls upon historians to approach emotions of the past in a different way, through the concept of "emotional communities," a model she uses in both of her tomes. According to Rosenwein, medieval people were members of emotional communities and these communities could range from households and monasteries to royal courts and neighborhoods. A person or goal would bind these communities together and they were fluid, individuals could transfer from one community to another, and each community had different forms of emotional expression and its own set of expectations about that expression. These expectations, of course, could evolve throughout time. Rosenwein stresses the necessity of analyzing these expectations in detail, specifically by looking at the language used to describe emotions, in order to truly understand the expectations of a

\footnotetext{
${ }^{40}$ Rosenwein, "Worrying about Emotions," 839; Barbara Rosenwein, Emotional Communities in the Early Middle Ages (Ithaca: Cornell University Press, 2006), 1.
} 
society and the ways in which a particular group may have worked together ${ }^{41}$ Rosenwein not only challenges historians to rethink approaches to studying past emotions, but also stresses the idea that historians must look at descriptions of emotions in order to understand the expectations that medieval writers placed on community expression.

\section{METHODOLOGY}

My dissertation continues the discussion of emotion associated with child death in the Middle Ages, but goes beyond simply demonstrating that medieval parents grieved when natural or accidental deaths occurred in and around the home. I examine how and why medieval authors described parents and community members as grieving in the ways that they did between the twelfth and fifteenth centuries in England, and what these descriptions can tell us about gendered-appropriate expressions of emotion, childrearing, religion, and familial and community roles in the Middle Ages. The study also moves outside the boundaries of the nuclear household in order to observe how members of the wider community participated in and interacted with those undergoing the mourning

\footnotetext{
${ }^{41}$ Rosenwein, "Worrying about Emotions," 842; Barbara Rosenwein, Generations of Feeling: A History of Emotions, 600-1700 (Cambridge: Cambridge University Press, 2016), 3-10. Rosenwein in, Generations of Feeling: A History of Emotions, 600-1700, also underscores the idea that emotional communities emphasized similar emotional expressions, but used them to relay different messages to their communities. She gives the example of the twelfth-century Cistercian community under Aelred praising the feeling of love. For Aelred, love could lead to positive outcomes like friendship and the love of God. Similarly, twelfth-century poets in the courts of Toulouse wrote songs praising love. Despite the similarities, the poets and Aelred used the emotion of love to put forth different messages to their emotional communities. Aelred employed love in his works to showcase both the positive effects of charity and to caution his fellow monks about the dangers of love leading to earthly desires, such as lust. On the other hand, the poets of Toulouse attached the feeling of betrayal to the notion of love in order to express "anxiety about treachery from the political realm," 88-143, 141.
} 
process in accounts of child death. The study will not be limited to a specific geographical location in England, but incorporates records of grief authored in, and that discuss, several areas around the English landscape. For instance, one source that I spend much time on is the Thomas Becket miracle collection, which was written in Canterbury. The miracles in the collection are not confined to a single location. Miracles containing instances of child death from this collection are reported in places like Northwood, Lichfield, Plumstead, Burton, and Ferring (to name only a few). In addition, some works include details about events happening outside of England. Some of the miracle compilers talk about miraculous deeds related to saints in France. Because the story was still authored by someone in England, it will still be considered in this study.

My project primarily expands the discussions in Gordon's article “Accidents Among Medieval Children as Seen from the Miracles of Six English Saints and Martyrs" and Finucane's work on child death accounts in The Rescue of the Innocents: Endangered Children in Medieval Miracles. Unlike Gordon and Finucane, however, I add more to the discussion about community intervention associated with child death, looking at how authors depicted community members (outside of the immediate household) in accounts of grief and child death. Additionally, I take on an interdisciplinary approach to understanding descriptions of emotion and child death. I not only analyze miracle stories, but also other written evidence, such as lullabies, poetry, and mystery plays. Moreover, I consider material evidence in the form of artwork and memorial brasses erected on behalf of children and their families. Some of the artwork, such as Douce 276 manuscript, discussed in Chapter One, is used to help reconstruct the dangers of medieval childhood, while other images, such as those from the Pearl 
manuscript, are used in conjunction with the written evidence to enhance my arguments about responses to child death. Orme does mention that memorial brasses were made on behalf of children. I expand the discussion and show how they could be physical displays of grief and examples that communities watched and prayed over children, even in death.

I also employ one important aspect of Rosenwein's model of emotional communities, specifically the idea that descriptions of emotions can be analyzed to determine expectations for groups of people, in this case the expectations are put forth by religious men and the groups of people that they talk about are parents and people outside of the immediate family. I have selected four groups of people that are mentioned in child death accounts: the immediate family, neighbors, bystanders at a death scene, and workers in a household. Barring the Simon de Montfort collection, I only focus on accounts that describe these types of people, child death, and the emotion of grief. My approach differs from Rosenwein in that I look at these groups of people through the lens of the authors who wrote about them and not from the actual people themselves. The "immediate family" category refers to parents of a child who dies. Siblings of a deceased child are not accounted for in this section because they are not mentioned in the accounts under consideration for this project. The "neighbor" category has been chosen because it is by far one of the most common descriptors of people present when child deaths occur in miracle stories. Finucane also pointed this out in his work. He found that neighbors in posthumous miracle stories were usually the first-finders of deceased children and were the second highest group to vow to go on pilgrimage in exchange for a child's healthy recovery. ${ }^{42}$ In miracle stories, the term "neighbor" does not always carry the same

\footnotetext{
${ }^{42}$ Finucane, The Rescue of the Innocents, 148.
} 
connation as it does today. Authors of miracles employed the word vicina (neighbors) to refer to people either living near the location of an accident or residing within the wider community. As a result of this broader usage of the term "neighbor," I will be looking at examples with both of these connotations, even though, for the most part, the examples used refer to people residing near the location of an accident. The next category, bystanders/those gathered at a death scene, is also found regularly in miracle accounts, though not as often as neighbors. Under this category, I will examine any accounts that mention "bystanders," "the people of a village," or a "crowd." For the last category, "workers in a household," I discuss one account from the Henry VI miracle collection referencing household servants since their job titles are specifically mentioned in reference to community.

All of the categories investigated in this project are fluid and may overlap with one another, but details about someone belonging to more than one category are not often provided in miracle stories. There are cases where the "neighbor" category may apply to a certain group gathered at a death scene, but not enough details are provided to know for certain. For instance, in a miracle story associated with Henry VI, the narrator states that a girl named Joan Knight died from a bone in her throat and astantibus, which literally translates to "those standing by," called for divine aid, but gives no other details of their relation to Joan or her community. ${ }^{43}$ In another case, the son of Richard Woodward died in Kennington after falling into a pool of water. People at the death scene are only

${ }^{43}$ Paul Grosjean, ed., Henrici VI Angliae Regis Miracula Postuma (Brussels: Society of the Bollandists, 1935), 130-131. 
referred to as a "crowd" (turba) ${ }^{44}$ In a Thomas Becket miracle, the people who gather around a drowned boy from Rochester are described as the "people of the village" (populi multitude), but no other information is given..$^{45}$ In accounts such as these, the relation to the victim, whether it be a relative, servant of a household, neighbor, or stranger, is not always clear.

The ages of children under investigation in this study vary and are sometimes unknown. Medieval writers described the aging process in much different ways than we do today and terms used to describe age are not always straightforward in medieval texts. For example, the term "child" could be used in reference to both a newborn or someone in their teen years. ${ }^{46}$ When authors of child death accounts list the age of a child, it will be noted in the analysis/description of the account. If age is not provided, especially in miracle stories, I only consider accounts where youth is implied by the words "infant" (infans), "boy" (puer), or "girl” (puella). Puer or Puella, can also be used interchangeably with "child." Medieval people described the childhood aging process in much different ways than we do today. "Baby" and "child" could be used to describe the young, regardless of a specific age. For instance, "child" could refer to an infant or someone in their teens. Today, we assign titles to stages in childhood based on milestones of development and age. Birth until the two-month marker is considered the "newborn" stage, whereas children who are starting to walk and are between twelve and thirty-six

\footnotetext{
${ }^{44}$ Grosjean, ed., Henrici VI, 209.

${ }^{45}$ Benedict of Peterborough, Materials for the History of Thomas Becket, Archbishop of Canterbury, Canonized by Pope Alexander III, A. D. 1173., ed., James Robertson, Vol. 2 (London: Eyre and Spottiswoode, 1876), 226.

${ }^{46}$ Orme, Medieval Children, 6.
} 
months are thought of as "toddlers." In the Middle Ages, children were also assigned stages of life until they reached adulthood, an idea which stemmed from classical writings and was known as the "Ages of Men." Some medieval writers separated the ages of men into as many as twelve stages, while Chaucer, in his famous work, The Canterbury Tales, used a tri-part model of life, broadening the categories to "youth," "maturity," and "old age," as exemplified in his characters the Squire, Knight, and the Franklin. ${ }^{47}$ More commonly, lifespans were divided into seven ages. In this model, infancy took place from a child's time in the womb until the age of seven, and then childhood lasted from the age of seven until the age of fourteen. ${ }^{48}$

The Pearl and the Brome Abraham and Isaac do not refer to the age of the children in the texts, however youth is still implied in the rhetoric. The father in the Pearl mentions that his daughter died young, and Abraham refers to Isaac as his young child (yowng child). ${ }^{49}$ While Isaac never dies in the mystery play, over the biblical version, Abraham's reaction to the thought of his death still can tell us much about expectations for paternal grief. I do not attempt to assign an age range based on a term, such as "puer" or "infans," because of the varying meanings each could carry. There is one major exception to this methodology in Chapter Two with passion lyrics, where an adult Christ is portrayed as dying on the Cross. These lyrics are used in direct comparison to the lullabies and stress the Virgin Mary's continued grief over the thought of her son's death.

\footnotetext{
${ }^{47}$ Orme, Medieval Children, 6.

${ }^{48}$ Orme, Medieval Childhood, 6.

${ }^{49}$ While Isaac is usually considered to be young in age, the Towneley Abraham and Isaac mystery play does not depict him as so. He is said to be thirty years old in order to link the idea of his sacrifice with the death of Christ.
} 


\section{THE SOURCES}

Miracle stories provide the foundation for this project. The main purpose of miracle stories, according to Patrick Geary in Living with the Dead in the Middle Ages, was to honor God through the glorification of an individual saint.$^{50}$ Miracles, including the ones about child death in this study, almost always have a happy ending, which proved a holy figure's sanctity. Historians of the past have shied away from using the literary genre as evidence to reconstruct the lives of actual medieval people, lest events be exaggerated to highlight the miraculous deeds of a person for canonization purposes. Every author of a source, though, had a bias that bled onto their pages. Authors of medieval works may have exaggerated, or even downplayed, events to get their points across. Even legal texts, such as coroners' rolls, which we may think of as being more "trustworthy" are not without problems. One striking example can be found in coroners' reports from Lincolnshire, where thirty female hangings were deemed "accidental deaths," probably to spare their families from being fined. ${ }^{51}$ Coroners' actively covered up felonious crimes in their reports, which results in coroners' records not being completely straightforward. The authors of all of these different texts were human, with their own beliefs, expectations, and concerns for the societies in which they lived. I agree with the historian Alexander Murray that "we do not have to believe all the miracles, or

\footnotetext{
${ }^{50}$ Patrick Geary, Living with the Dead in the Middle Ages (Ithaca: Cornell University Press, 1994), 22.

${ }^{51}$ Sara Butler, "Women, Suicide, and the Jury in Later Medieval England," Signs: Journal of Women in Culture and Society 32, no. 1 (2006): 149.
} 
indeed any of them, to put them to use" for historical research. ${ }^{52}$ Thus, although I do not know the exact veracity of each account in terms of spoken words and actions in the sources considered here, they nevertheless help in the understanding of parental and community grief and duties as they were supposed to be performed, even if not necessarily as they actually happened. In other words, I will be using miracles to understand the expectations of their authors, rather than trying to prove that what they were saying actually took place. See Appendix 1 for chart of miracles under consideration.

The main miracle collections under consideration are those of Wulfstan, the Bishop of Worcester, Thomas Becket, the archbishop of Canterbury, Thomas of Cantilupe (also known as Thomas of Hereford), the Bishop of Hereford, and King Henry VI. While the Simon de Montfort collection only includes one miracle account containing emotional dialogue, it will still be considered because several miracles include cursory notes about the involvement community members at the child death scene. The reason these particular miracle collections were chosen was because they contain instances of child death, but also because of the scarcity of miracle collections between the early thirteenth and sixteenth centuries. Rachel Koopmans, when discussing this lacuna in Wonderful to Relate, says that one reason for the lack of miracles might be because "so many collections now existed for saints." ${ }^{53}$ Whether this was the case remains unclear. One possibility not mentioned by Koopmans, is that some miracle collections produced

\footnotetext{
${ }^{52}$ Alexander Murray, Suicide in the Middle Ages, Vol. 1 of The Violent against Themselves (Oxford: Oxford University Press, 1998), 252.

${ }^{53}$ Rachel Koopmans, Wonderful to Relate (Philadelphia: University of Pennsylvania Press, 2011), 202.
} 
during this time may simply not have survived in the medieval corpus. Another

possibility is that, because the canonization process became more rigid during this period, fewer miracles were actually put through the canonization process for review. A brief background about the sources will now follow.

Thomas Becket was the Archbishop of Canterbury from 1162 until his martyrdom in 1170. Outrage over his murder by King Henry II's knights prompted his immediate canonization. While William of Canterbury and Benedict of Peterborough composed narratives of his miracles between 1170 and 1184, he was officially canonized in 1173 and his relics were translated to an elevated tomb at the east end of Canterbury Cathedral in $1220 .^{54}$ To borrow a phrase from Alyce Jordan, "Thomas Becket was nothing short of a medieval celebrity," as evidenced by the numerous miracles attributed to him. ${ }^{55}$ His cult gained widespread popularity after his death, and the former archbishop's shrine became one of the most popular pilgrimage destinations in Europe, especially since his blood, which was supposedly diluted with water from the cathedral cistern, made for a portable relic. Pilgrims across England, Wales, and Europe flocked to his shrine at Christ Church, Canterbury to worship, obtain Becket water, and receive cures for ailments. ${ }^{56}$ Thomas Becket's combined collection contains 556 miracles, with fifty-four of those accounts

\footnotetext{
${ }^{54}$ Alyce Jordan, "The "Water of Thomas Becket": Water as a Medium, Metaphor, and Relic," in The Nature and Function of Water, Baths, Bathing, and Hygiene from Antiquity through the Renaissance, eds. Cynthia Kosso and Anne Scott (Leiden: Hotei Publishing, 2009), 479.

${ }^{55}$ Jordan, "The "Water of Thomas Becket," 479.

${ }^{56}$ Gordon, “Accidents Among Medieval Children,” 147-148.
} 
containing descriptions of child deaths. Eighteen of these include descriptions of parents, communities, and grief.

Thomas of Cantilupe was appointed the Bishop of Hereford in 1275 and had a somewhat prolonged road to canonization. After a feud regarding jurisdiction in Hereford with John Pecham, the archbishop of Canterbury (1279-1292), ending in excommunication for Thomas of Cantilupe. In April of 1307, Pope Clement V, still uncertain whether or not to proceed with the bishop's canonization, began an investigation into his sanctity, specifically questioning whether or not he was an excommunicate at the time of his death. By June of the same year, the investigation ended and his canonization process began. Despite the end to the investigation, Thomas of Cantilupe was not officially recognized as a saint until 1320, under Pope John XXII. ${ }^{57}$ His miracles survive in the Vatican Latin 4015 manuscript, and some are also recorded in the Acta Sanctorum. Because the miracles from the Vatican Latin 4015 have not yet been published and the manuscript is not digitalized, I will be using miracles from the Acta Sanctorum and two miracles attributed to the saint that are translated by Finucane in The Rescue of the Innocents: Endangered Children in Medieval Miracles. ${ }^{58}$ In the Acta Sanctorum, there are a total of twenty-four miracles involving child death and of these, five contain details about either parental or community reactions to child death.

\footnotetext{
${ }^{57}$ Robert Bartlett, The Hanged Man: A Story of Miracle, Memory, and Colonialism in the Middle Ages (Princeton: Princeton University Press, 2004), 23, 122.

${ }^{58}$ Gordon, "Accidents Among Medieval Children," 147-148; Finucane, The Rescue of the Innocents, 4. Susan Ridyard is working on translations of Thomas of Cantilupe's miracles and I will be looking into her work for future research.
} 
Wulfstan was the Bishop of Worcester from 1062 until his death in 1095. A vita, or biography about his life, was written first in Old English by a monk from Worcester named Coleman between 1095 and 1113, and then by the historian William of Malmesbury in Latin later in the twelfth century. ${ }^{59}$ It was not until the thirteenth century, however, that Wulfstan was formally canonized (1203). Anonymous chroniclers compiled records of his miracles from 1203 until $1220 .^{60}$ Within this compilation, there is a total of sixty-nine miracles, with six about child death. Five of these contain information about responses to child death.

King Henry VI's reign and road to sainthood was tumultuous, to say the least. He reigned intermittently between 1422 and 1471 because of episodes of illness and conflict over the throne during what Shakespeare would coin the "Wars of the Roses." Henry VI was killed in 1471, probably by the orders of Edward IV. As pilgrims began worshiping at Henry VI's resting place in Chertsey, an action which was viewed as "an embarrassment to the government," his tomb was translated to Windsor and Edward IV placed a royal prohibition on his cult. ${ }^{61}$ Despite Edward IV's best efforts to disassociate the ruler from any saintly characteristics, Henry VII started the canonization process for Henry VI in 1494, and the Dean of Windsor asked an unknown chronicler to compile miracle testimonies from beneficiaries that visited Henry's tomb from 1481 until 1500. While Henry VI's miracles were recorded, the rise of King Henry VIII to the throne left

\footnotetext{
${ }^{59}$ William of Malmesbury The Vita Wulfstani of William of Malmesbury, ed. Reginald Darlington (London: Offices of the Society, 1928), viii.

${ }^{60}$ Gordon, “Accidents Among Medieval Children,” 147.

${ }^{61}$ Finucane, The Rescue of the Innocents, 4; Danna Piroyansky, Martyrs in the Making: Political Martyrdom in Late Medieval England (Houndmills: Palgrave, 2008), 75.
} 
the canonization process incomplete and Henry VI would never reach sainthood. ${ }^{62}$ Between 1481 and 1500, 174 miracles were recorded and twenty-five are child deaths. Twelve involve parents and community members.

Simon de Montfort, the Earl of Leicester who led a rebellion against Henry III, also never received the title of "saint." He died in 1265 at the Battle of Evesham, and monks at Evesham Abbey compiled his miracles.$^{63}$ The accounts of his miracles are different than the rest in that they are brief and do not include much detail about the emotions of the people involved in the stories. The possible reasons for this scarcity of information will be discussed more in Chapter Four, when Simon de Montfort's miracles are under inspection. His collection has a total of 191 miracles and fourteen are about child death.

One miracle included in the biography of Saint Edmund Rich of Abingdon is also considered in this project because it contains elaborate emotional dialogue and imagery about a child death. Edmund Rich studied at both Oxford and Paris and became the archbishop of Canterbury in the thirteenth century. He was canonized in 1246. There were several biographies written about his devout life. Four are anonymous (The Pontigny Life, the Anonymous A, B, and C), and one is written by Eustace of Faversham and another by Matthew Paris. The Anonymous B, which contains the instance of child death, will be the one under investigation. Hugh Lawrence explains that while the

\footnotetext{
${ }^{62}$ Gordon, "Accidents Among Medieval Children," 147-148.

${ }^{63}$ Gordon, “Accidents Among Medieval Children,” 147-148.
} 
Anonymous B is English in origin, the exact location of its compilation remains unknown. ${ }^{64}$

In addition to miracle accounts, this study also considers Nativity lullabies and Passion lyrics. Lullabies about the Nativity became popular in England in the fourteenth century and offer imagery about the Virgin Mary's reaction to the prophecy of the Christchild's death, while Passion lyrics focus upon her maternal grief as Christ's death occurs on the Cross. Mary's grief was a central theme of medieval religious verse and became more popular in lyrics with the introduction of the planctus and the emphasis on Christ's humanity in the later eleventh century. ${ }^{65}$ Originally, lyrics about the Passion were intended to be used for liturgical purposes, for readers/hearers to envision the suffering of Christ but were sometimes incorporated into the texts of mystery plays. ${ }^{66}$

The anonymous Middle English poem the Pearl will also be used as evidence. The alliterative poem dates to the fourteenth century and is extant in the MS Cotton Nero A.x, Art. 3 at the British Library. The manuscript contains three other poems: Sir Gawain and the Green Knight, Cleanness, and Patience ${ }^{67}$ The Pearl contains imagery about a father grieving the loss of his daughter, whom he likens to a perfect pearl. Another source

${ }^{64}$ Hugh Lawrence, St. Edmund of Abingdon: A Study in Hagiography and History (Oxford: Clarendon Press, 1960), 61-63.

${ }^{65}$ Reginald Davies, ed., Medieval English Lyrics: A Critical Anthology (Northwestern: Northwestern University Press, 1964), 40; The term planctus refers to a lament or dirge.

${ }^{66}$ Rosemary Woolf, The English Religious Lyric in the Middle Ages (Oxford: Clarendon Press, 1968), 19-23.

${ }^{67}$ Malcolm Andrew and Ronald Waldron, eds., The Poems of the Pearl Manuscript: Pearl, Cleanness, Patience, Sir Gawain and the Green Knight (Berkeley: University of California Press, 1978), 16. 
that showcases fatherly grief is the script of the Brome Abraham and Isaac mystery play, also written by an unknown author. The text of the play is extant in a fifteenth-century commonplace book, now housed at Yale University Library. The dialect of the play is East Anglian and was written down after $1454 .{ }^{68}$ This mystery play would have been performed on special feast days, such as Whitsunday, usually in corroboration with local guilds. ${ }^{69}$ Although six Abraham and Isaac mystery plays survive, I will only be examining the Brome version in order to narrow down the scope of my project.

Other textual evidence such as coroners' rolls, medical texts, priests' instruction manuals, encyclopedic texts, homilies, and prayer books, are considered alongside miracle stories, lyrics, mystery plays, and poetry. These sources will be introduced in the following chapters and serve to provide a glimpse into the anxieties about and dangers of childhood, reinforce the arguments that children were considered vital members of medieval societies, with their own identities and roles within a community, and to show that both family members and non-relatives were held responsible for keeping children safe from day-to-day dangers.

\section{CHAPTER BREAKDOWN}

The first chapter titled "Death is Hiding Around a Dark Corner: The Dangers of Medieval Childhood," gives a brief overview of child mortality rates in order to show how common child death was in the Middle Ages. Next, there is a discussion of the types

\footnotetext{
${ }^{68}$ John Coldewey, ed., Early English Drama: An Anthology (New York: Garland Publishing, 1993), 136.

${ }^{69}$ Coldewey, ed., Early English Drama, 1.
} 
of dangers that children frequently encountered on a daily basis. I employ medical and religious texts to demonstrate the anxieties that medieval people had about child death, as well as coroners' records and miracle stories to show some of the types of child death that occurred in England. I begin the discussion of causes of child death with the fragile moments of childbirth and move on to address accidental deaths that occurred in and around the household. Within this section, I also look at the efforts taken by community members to prevent child mortality. Finally, I outline the legal protocol in cases of child death in order to show how residents of a community were expected to behave legally when tragedy struck. The first chapter is intended to set the stage for discussions of grief and child death in the following three chapters.

The second chapter, "I Should Have, But I Was Blind: Displays of Maternal Grief," focuses on maternal responses to child deaths around the English household and community. Here, I examine saint's miracles attributed to Wulfstan, Thomas Becket, Thomas of Cantilupe, and Henry VI. In addition, I consider medieval lullabies that depict the Virgin Mary grieving over the prophecy of Christ's death and Passion lyrics, which contain imagery of the Holy Mother mourning as Christ dies on the Cross. The third chapter, "I Beg You Father, Do Not Mourn For Me: Displays of Paternal Grief," investigates paternal reactions to child death within the same miracle collections. Discussions of the Brome Abraham and Isaac mystery play and the Middle English Pearl are also included in this chapter. The main goals of these chapters are to elucidate how the authors described women as grieving their children in comparison to men. I look at the language and behavior applied to fathers and mothers in order to understand why 
medieval authors portrayed men and women as expressing grief in the ways in which they did.

The fourth and final chapter, "Neighbors Ran to the Sound of Their Strange Cries: Community Responses to Child Death," focuses on the miracle stories of the four aforementioned men, with additional discussion of the Simon de Montfort collection. The chapter addresses the reactions of neighbors or crowds gathered at a death scene to child death. I specifically observe how writers portrayed crowds and neighbors interacting with deceased children, their grieving families or caretakers, and how communities are portrayed as grieving themselves.

By bringing together the historical and material evidence on grief in relation to child death from the twelfth until the fifteenth century in England, this dissertation contributes to the growing field of childhood studies and the history of emotions. It goes beyond confirming that medieval communities grieved the death of children. It looks at intimate moments between children and community in order to enhance our understanding of how medieval religious authors used grief to put forth their expectations for child care, familial roles, community unity, religious duties, and mourning. Furthermore, the project contributes to our understanding of how communities physically displayed emotion and remembered children through acts of commemoration. 


\section{Chapter 1}

\section{"Death is Hiding Around a Dark Corner": The Dangers of Medieval}

\section{Childhood}

Medieval communities were alive with activity. Hanawalt paints a vivid picture of the activity of village life and the inner workings of the medieval peasant household during the fourteenth and fifteenth centuries in England. When discussing daily life in rural areas, she writes:

Although the villages and hamlets were not picturesque, they were filled with lively activity during the daylight hours. The houses...were uninviting, so that as much as possible people did their play and daily routine out of doors... Reading the coroners' inquests, one can easily imagine this world of neighbors as a noisy one with a bustle of activity. Children ran among the crofts at play, although by the age of ten they might be herding geese or animals. Babies cried in cradles by the hearth. The usual barnyard noises of pigs, sheep, poultry, horses, and oxen filled the air. Carts rumbled through the village when the streets were dry and occasionally got stuck in the mud when it rained. A village smith might be clanging away. During the daytime women dominated the village streets, fetching water, washing clothes, calling to children, and working about their closes...The peasant communities were not sleepy villages by any means. ${ }^{70}$

Residents of cities, too, would have come across various sights, sounds, and smells in their everyday life. Inhabitants would have witnessed the traffic of animals and people

\footnotetext{
${ }^{70}$ Hanawalt, The Ties That Bound, 29.
} 
entering and exiting city gates, children playing in the streets in front of their houses or tenement rooms, groups socializing at taverns, people begging for alms, refuse being swept from houses into the streets, and guildsmen working away in their street-side workshops. $^{71}$

Amidst of all this activity in villages and cities, medieval people would have witnessed a staggering number of child death, both in and around the household, as well as around the wider community. Mothers and fathers would have held dying infants in their arms, children would have lost siblings while playing in bodies of water, midwives would have desperately attempted to give emergency baptisms to newborns perishing after delivery, neighbors would have witnessed the children that they saw on a daily basis succumbing to injuries on the streets, and godparents would have attended funerals for their namesakes. Child death was all around. The objective of this chapter is to provide an overview of the dangers of medieval childhood, which will set the foundation for the discussion of grief and child death in the next three chapters. First, I address estimated child mortality rates of the Middle Ages in order to provide a better understanding of how many children perished before reaching adolescence and adulthood. Second, I discuss the hazards that children encountered in daily life, starting from the risks of the birthing process and moving on to dangers around the household and community, such as accidents associated with the hearth, animals, and performing household chores. Some of the texts that describe the childhood dangers contain emotional dialogue in order to stress the anguish that people associated with child death. Within this discussion, I will also

${ }^{71}$ Hanawalt, Growing Up in Medieval London, 23-40. In the chapter, "Material Environment of London's Youth," Hanwalt gives readers a sense of what city life would have been like, through the lens of medieval children. 
touch upon efforts to prevent child death in medieval communities, as evidenced in medieval texts and artwork.

\section{CHILD MORTALITY RATES}

Childhood in the Middle Ages was perhaps the most fragile stage in human development. Debates about exact child mortality rates are ongoing. Orme argues that there is no way to pinpoint death rates for medieval children because "conditions changed from year to year and place to place." 72 In addition, child burials, are complex and do not provide a straightforward image of child mortality. For one, stillborn children were not always recorded in parish registers and unbaptized children may be absent from cemetery excavations because they were considered "unclean and perhaps fearful objects that might return from the dead" and were therefore not allowed to be buried on consecrated ground, especially by the later Middle Ages. ${ }^{73}$ In fact, in 1389, Hereford Cathedral was given a royal license to enclose its cemetery with walls and gates in order to prevent the illegal burial of unbaptized babies. This, however, did not completely stop people from trying to bury their dead. ${ }^{74}$ Grave cutting, which could render skeletons incomplete or destroy skeletal remains altogether, and the quick decay of infant remains also make

\footnotetext{
${ }^{72}$ Orme, Medieval Children, 113.

${ }^{73}$ Shahar, Childhood in the Middle Ages, 51-2; See also Roberta Gilchrist and Barney Sloane's Requiem: The Medieval Monastic Cemetery in Britain (London: Museum of London Archaeology Service, 2005), 72.

${ }^{74}$ Orme, Medieval Children, 126; Also, Gilchrist and Sloane, Requiem, 72. Gilchrist and Sloane point out that some unbaptized infants may have been included in cemetery burial. There are four prone neonate burials in monastic cemeteries like Northampton Marefair and Linlithgow. These infants were probably buried prone to indicate that they were not baptized, and also to prevent them from returning to the physical realm.
} 
determining death rates difficult. Archaeologists, such as Sally Crawford and Kirsty Squires, though focusing on child interments from the Anglo-Saxon period, posit that many child graves may be absent from the archeological record because the English soil was so acidic that their fragile bones were more vulnerable to "taphonomic decomposition." 75

Despite the difficulties of determining child death rates, historians of medieval childhood estimate that rates are similar to late-Tudor death counts, with 400-500 children out of every thousand dying before the age of ten. Approximately $124(12.4 \%)$ children died between the ages of one and four, and fifty-nine (6\%) perished between five and nine years of age. Out of the 400-500 children that died before reaching the age of ten, boys tended to outnumber girls, with 148 boys dying in the first year of life compared to 127 girls, and sixty-five boys to fifty-nine girls dying between one and four. After the age of four, the ratio of female to male deaths starts to even out. ${ }^{76}$ Orme compares these statistics to death rates of royal children between 1150 and 1500 in England in order to show that they are probable. Between 1150 and 1500, approximately

\footnotetext{
${ }^{75}$ Kirsty Squires, "Through the Flames of the Pyre: The Continuing search for AngloSaxon Infants and Children," in Medieval Childhood: Archaeological Approaches, eds. Dawn Hadley and Katie Hemer (Oxford: Oxbow Books, 2014), 115; Sally Crawford, "Children, Death, and the Afterlife," Anglo Saxon Studies in Archaeology and History 5 (1993), 84; Howard Williams also talks about the difficulty of identifying remains, and not just those of children, because of soil acidity. He is specifically referring to excavations done at Sutton Hoo. See Williams, "Death, Memory and Time," in Time in the Medieval World, ed. Chris Humphrey and William Ormrod (Woodbridge: York Medieval Press, 2001), 59.

${ }^{76}$ Edward Wrigley and Roger Schofield, The Population History of England 1541-1871 (Cambridge: Cambridge University Press, 1981), 248-249, 528; These statistics are from Wrigley and Schofield's analysis of twelve English parishes from 1550-1590: Alcester, Aldenham, Banbury, Colyton, Gainsborough, Gelding, Hartland, Methley, Shepshed, Southill, Terling, and Willingham.
} 
thirty-four out of ninety-six royal children died within the first year of life. Eleven perished between one and ten years of age, and another eleven between the ages of ten and twenty. Only forty reached their twenties. He admits that these royal death statistics do not present a full picture of child mortality, because it does not account for unreported stillborn deliveries and the sample size reflects only families of the upper classes that would have had a better standard of living and more access to medical care. ${ }^{77}$

The waves of plague that ravaged England undoubtedly increased the already high mortality rates of children. The spread of disease with the Black Death in 1348 would have killed many children, especially those with more vulnerable immune systems, such as newborns and those who were already sick. ${ }^{78}$ Gilchrist, Sloane, and Zvi Razi, when discussing the epidemic, explain that each wave of the plague affected child mortality differently. Razi found, when examining manorial records, that the first wave of plague killed off the very young and elderly, leaving rural communities with residents in their $20 \mathrm{~s}$ and $30 \mathrm{~s}^{79}$ Sloane, on the other hand, argues that in London, the pestis secunda (second wave of plague) of 1360-1362 was "an aftershock to a massive earthquake" and

\footnotetext{
${ }^{77}$ Orme, Medieval Children, 113. Orme uses two works to tally death rates. See John Parson's "The Year of Eleanor of Castile's Birth and her Children by Edward I," Medieval Studies 46, no. 1 (1984): 245-265, and Frederick Fryde et al., Handbook of British Chronology, $3^{\text {rd }}$ edition (London: Royal Historical Society, 1986), 37-42.

${ }^{78}$ Sharon DeWitte, "Age Patterns During the Black Death in London, A. D. 1349-1350," Journal of Archaeological Science 37, no. 12 (December 2010): 339-340.

${ }^{79}$ Zvi Razi, Life, Marriage, and Death in a Medieval Parish: Economy Society and Demography in Halesowen 1270-1400 (New York: Cambridge University Press, 1980); See also Gilchrist and Sloane, Requiem, 209.
} 
that it was a particular threat to children, more so than the first round of plague ${ }^{80}$ Sloane asserts that wills and testaments, such as wills made at the Court of Husting in London, which included instructions of parents wishing to be buried near the tombs of their predeceased offspring, act as evidence of increased child mortality. Additionally, coffins for infants in East Field Cemetery increased from twenty percent in the 1348-1349 outbreaks to over fifty-one percent during the second pestilence. ${ }^{81}$ Reports about the impact that the second pestilence had on children are found not only in London. In Yorkshire, for instance, Thomas Burton, a fifteenth-century abbot at Meaux Abbey in East Riding, alluded to the devastation that the epidemic inflicted on the young. In a passage from his Chronica monasterri de Melsa, he deemed the plague the pestilentia puerorum, or the "pestilence of the children." 82

\section{CAUSES OF CHILD DEATH AND CHILD SAFETY}

Medieval children encountered dangers during every stage of development, but some of the most fragile moments of childhood were the ones during and directly following birth. Childbirth was a dangerous process in the Middle Ages, for both mother and child. According to Shahar, childbirth alone accounted for a large number of child deaths in Europe throughout the medieval period. Again, using late-Tudor child death

\footnotetext{
${ }^{80}$ Barney Sloane, The Black Death in London (Stroud: The History Press, 2011), 142; See also Orme, Medieval Children, 107.

${ }^{81}$ Sloane, The Black Death in London, 141.

${ }^{82}$ Thomas Burton, Chronica Monasterii de Melsa, a Fundatione Usque ad Annum 1396, ed. Edward Bond, Vol. 3 (Cambridge: Cambridge University Press, 2012), 162. Thomas Burton gives no other detail about the plague or numbers of mortality, just applies this title to the epidemic.
} 
rates compiled by historical demographers, she estimates that approximately twenty-five out of every 1,000 women died from childbirth and at least thirty percent of infants died during delivery. The death toll increased during times of epidemic and famine, and when women had a caesarean procedure. ${ }^{83}$

Much preparation was made for royal births. A room was prepared for the expectant mother at least a month before she was going to give birth. At the time of labor, cloth was draped over windows and the birthing bed, and an obstetrix, or midwife, assisted both mother and child ${ }^{84}$ Women in rural areas also gave birth at home in darkened and warmed rooms, if possible. Jeremy Goldberg argues that the purpose of heating and darkening a room was to "mimic the womb" in order to soothe mothers and newborns. ${ }^{85}$ Women in rural areas sometimes gave birth with the help of midwives; however, it was more likely that non-professional midwives, such as female relatives and neighbors, aided in the process ${ }^{86}$ Although childbirth has been thought of as the territory of women, husbands assisted wives, if midwives or neighbors were not readily available

\footnotetext{
${ }^{83}$ Shahar, Childhood in the Middle Ages, 35; See Wrigley, The Population History of England, 248-249; Also Jeremy Goldberg, "Life and death: the ages of man," in A Social History of England 1200-1500, eds. Rosemary Horrox and William Ormrod (Cambridge: Cambridge University Press, 2006), 416. Golberg states that there is archaeological evidence of mothers with infants still lodged in their pelvis, but exact childbirth death rates do not exist from the high and late Middle Ages; Gilchrist and Sloane, in Requiem, argue that, in most cases, of childbirth deaths, the infant was extracted from the mother. In the thirteenth century, the Council of Canterbury said that it would be unlawful to bury a woman until the fetus was removed from her body, 72 .

${ }^{84}$ Orme, Medieval Children, 17-21.

${ }^{85}$ Goldberg, "Life and Death," 415.

${ }^{86}$ Goldberg, "Life and Death, 415.
} 
to help. ${ }^{87}$ To make sure that birthing process did not go awry, midwives, relatives, and neighbors recited prayers over the expectant mother and unborn child. ${ }^{88}$ Moreover, they provided water for the mother, helped her bear down, and assisted with the passage of the fetus through the birth canal. ${ }^{89}$ Shahar asserts that "childbirth was undoubtedly considered a most important event, and, within the limitations of the means and the know-how at their disposal, people did all they could for mother and child." 90

The anxiety about the pain and dangers associated with childbirth are represented in medical, religious, and encyclopedic texts, as well as in the precautions expectant mothers took in preparation for labor. ${ }^{91}$ It is important to keep in mind that the authors of

${ }^{87}$ Goldberg, "Life and Death," 415.

${ }^{88}$ Shahar, Childhood in the Middle Ages, 37-38.

${ }^{89}$ Judith Bennett and Ruth Karras, eds., The Oxford Handbook of Women and Gender in Medieval Europe, 325.

${ }^{90}$ Shahar, Childhood in the Middle Ages, 39.

${ }^{91}$ Anxiety about the safety of unborn children, before labor took place, is also seen in the Trotula. The Trotula contained three medical treatises about female health: On the Conditions of Women, On Women's Cosmetics, and On Treatments for Women. While, the Trotula is often attributed to a mysterious female healer named Trota from Salerno, Monica Green contends that the authorship of the three texts remains veiled in uncertainty, and that many historians believe these texts were written not by a woman, but a male physician. By the fifteenth century, the three works were combined and translated from Latin into European vernacular languages, making it more accessible to wider audiences. The author of the Trotula wrote that, to preserve the fetus, which according to Galen was attached to the womb like a piece of fruit and could therefore be destroyed by any sort of accident or injury within the first couple of months of pregnancy, a woman was not to purge or let blood before the fourth month, lest the fetus be completely destroyed. It is significant to note that, although scholars know that the Trotula was widely distributed throughout western Europe, it is difficult to know how many medieval mothers actually used its remedies. Nevertheless, the text highlights concerns that communities had for mothers and children. See Monica Green, Trotula: An English Translation of the Medieval Compendium of Women's Medicine (Philadelphia: University of Pennsylvania Press, 2002), xi-xii, 77-78. 
sources about the dangers of birth were written by men, not the women experiencing the pangs of labor. Thus, we do not get a first-hand account about dangers from the mothers themselves. The unknown author of the Hali Meidenhad (Holy Maidenhood), a thirteenth-century Middle English alliterative homily from the West Midlands, discusses, in detail, the suffering of laboring mothers. The author's main objective is to dissuade women from marrying, and instead take up religious vows. He lauds women who choose a spiritual marriage with Christ, using bride of Christ imagery, while putting forth a "scathing denunciation of secular life." "92 Ellen Powers even calls this homily an "entirely materialistic attack upon the state of matrimony." 93 Thus, an overly negative description of childbirth is put forth. Still, the account offers a look into the possible hazards of childbirth:

Think about what joy comes about after the birth of a child, when the offspring in you quickens and grows. How many miseries befall you therewith, that cause woe...Y Your rosy face will turn green as grass [Pi rudie nebb sehal leanin, ant ase gres grenin]. Your eyes will turn dusky and pale underneath [Pine ehnen sehule doskin, \& underneoð wonnin] and your brain will be turned upside down, so that your head will ache. Within your womb, your swelling uterus bursts forth like a water bag... heaviness is in every limb... Ah, wretch! The anxiety about the pain will deprive you of sleep. When it actually happens, there is sore sorrowful anguish, strong pains, restless ill, pain upon pain, and wandering lamentation

${ }^{92}$ Elizabeth Robertson, Early English Devotional Prose and the Female Audience (Knoxville: The University of Tennessee Press, 1990), 78.

${ }^{93}$ Elleen Power, Medieval English Nunneries (Cambridge: Cambridge University Press, 2010), 525. 
[Hwen hit Penne Per-to kimed, Pet sore sorhfule angoise, Pet stronge \& stinkinde stiche, Pet unroles uuel, Pet Pine ouer Pine, Pet wondrinde geomerunge]. ${ }^{94}$

The author emphasizes the bodily pain that women experience during labor. The pain of labor, the author states, is so strong that it changes one's physical features completely. It turns one's face green, the eyes become pale, as if dead, the head aches, and the uterus bursts through the womb, as if it were a heavy bag of water. What is more, the suffering is so strong, that it instills fear in the mind long before labor occurs.

Bartholomaeus Anglicus, a member of the Franciscan order and a scholastic of Paris, also commented on the suffering of women during birth in his encyclopedic text titled De proprietartibus rerum, which he wrote in Saxony around $1240 .{ }^{95}$ John Trevisa, a writer from Cornwall translated this work into Middle English in the fourteenth century. About women giving birth, Bartholomaeus reported:

The mother brings forth her child with sorrow and pain. During labor, they [women] are compelled to cry and easily perish, namely young women with small

\footnotetext{
${ }^{94}$ Frederick Furnivall, ed., Hali Meidenhad: An Alliterative Homily of the Thirteenth Century, Early English Text Society (New York: Greenwood Press, 1969), 48-51: "Ga we nu forðre, \& loki we hwuch wunne ariseð Prefter i burPkerne of bearne, hwen Pet streon in Pe awaken \& waxeoð. \& hu monie earmðen anan awakeneð Perwið, Pe wurcheð Pe wa inoh...Pi rudie nebb sehal leanin, ant ase gres grenin. Pine ehnen sehule doskin, \& underneoð wonnin; Pine heaued aken sare. Inwið i Pi wombe, swelin Pi butte, Pe bereð Pe forð as a weater bulge... heuinesse in euch lim...a, wrecche! Pe carest agein pi pinunge Praen binemeð Pe nahtes slepes. Hwen hit Penne Per-to kimeð, Pet sore sorhfule angoise, Pet stronge \& stinkinde stiche, Pet unroles uuel, Pet Pine ouer Pine, Pet wondrinde geomerunge."

${ }^{95}$ Elizabeth Keen, The Journey of a Book: Bartholomew the Englishman and the Properties of Things (Canberra: ANU E Press, 2007).
} 
and narrow members. The more woes and sorrow a woman has in childbirth, the more she will love the child when it is born. ${ }^{96}$

Bartholomaeus, like the author of the homily, points out the discomfort of and dangerous nature of childbirth, especially the fact that women could die during the process. They also use emotional dialogue to get their points across. The author of the homily employs the emotions of fear and grief to describe birth in order to turn women away from the secular realm. Bartholomaeus repeats the idea that sorrow surrounds the birthing scene. Sorrow for the pain of the mother, but also because of the possibility of death. Most medieval women, no matter what their size, and their newborns, faced complications during labor or post-partum. Women could lose too much blood and die from difficult, prolonged labor, while newborns could be born with fatal disabilities, be stillborn, or succumb to diseases after birth.

The Laud Misc. 724, a fifteenth-century manuscript from England that is currently housed at the Bodleian Library, is a collection of Latin surgical texts, which contains images of treatments for illnesses and medical examinations, as well as two sets of illustrations of fetus positions in the womb that may have contributed to difficult labor. At the top of the first diagram (fol. 097r), there is an image of a woman giving birth. She pulls on a cord, attached to the ceiling (border of the diagram), and is assisted by two midwives at both ends of the birthing bed. Below this image, are ten drawings of babies

\footnotetext{
${ }^{96}$ Bartholomaeus Anglicus, On the Properties of Things: John Trevisa's Translation of Bartholomaeus Anglicus De Propietatibus Rerum, ed. Michael Seymour et al. (Oxford: Clarendon Press, 1975), 303: "Pe modir...bringiP forP here child wiP sorwe and wiP woo...In trauaile of childe Pey beP compelled to crie, and ligtliche imperischid, and nameliche Yonge wymmen with smale membres and streit. Pe more woo and sorwe a woman hath in trauaile of childe, Pe more heo loueP Pat childe whenne he is ibore."
} 
in different womb positions. Some show more dangerous birthing positions than others. Some babies are horizontal with their arms either spread outwards or to their sides, some vertical, and some in a sitting position. All are in the supine position. The next manuscript page (fol. 097v) is a continuation of the diagram, with five more positions, including the positions of two sets of twins. ${ }^{97}$ Monica Green suggests that surgeons or physicians may have shown these images to midwives for instruction. ${ }^{98}$ While this is difficult to prove, it nevertheless demonstrates the dangers of the birthing process and the need to be prepared for a bad outcome. Authors of medieval miracle stories reinforce the idea that prolonged labor could be dangerous by painting gruesome images of newborns being born with contorted limbs, or even as rotting masses of flesh. In one delivery story associated with Simon de Montfort, a woman named Margery gave birth to a son whose right arm was completely bent backward because of prolonged labor..$^{99}$

Knowing about the potential dangers of childbirth, medieval women were encouraged, by religious authority, to take precautions to prevent and prepare for complications caused by childbirth. In his Middle English Instructions for Parish Priests, compiled around 1400, John Mirk, a canon at Lileshall, wrote about a variety of topics concerning children, such as baptism, midwifery, and childbirth. The purpose of this manual was for priests to draw on Mirk's words when asked for counsel by members of

\footnotetext{
${ }^{97}$ Digital images of folio 097r and 097v can be found on the Bodleian online digital collection. Not all of the manuscript is digitalized.

${ }^{98}$ Monica Green, Making Women's Medicine Masculine (Oxford: Oxford University Press, 2008), 152.

${ }^{99}$ James Halliwell, ed., The Chronicle of William de Rishanger; The Miracles of Simon de Montfort, Camden Society, Vol. 15 (London: John Nichols and Son, 1840), 107.
} 
their flock. According to Mirk, priests should advise pregnant women to go to confession and receive the Eucharist before labor. In lines 77-84, he pointed out: "Women that are with child / Although most of them are taught what they should do / When the time is at hand / Tell them to do all and some: Teach them to come and confess themselves clean / And also have them receive communion before God / because of the dread of peril that may befall [during labor]." ${ }^{100}$ In this passage, Mirk reminds priests that labor can end in death for both mother and baby, and that women should confess their sins and receive communion in order to avoid a bad death. Being unprepared for death was a major concern in the minds of high- and late-medieval people. Dying quickly or unexpectedly meant that one could not receive last rites, a crucial aspect of the penitential cycle. ${ }^{101}$ Because baptism did not completely remove the stain of original sin, medieval people were constantly engaged in the struggle against sin and were required to participate in the sacraments up until the time of their death. Thus, preparing women for all outcomes of childbirth was necessary for parish priests. Religious authority also had concerns about the salvation of newborns. If a newborn looked as though it might perish after birth,

100 John Mirk, Instructions for Parish Priests, ed. Edward Peacock (London: English Text Society, 1902), lines 77-84: "Wymmen that ben wyth chyde also / Thow moste hem teche how pey schule do. / Whenne here tyme ys neghe y-come, / Bydde hem do thus alle \& some: Theche hem to come \& schryue hem clene, / And also hosele hem bothe et ene, / For drede of perele that may be-falle."

101 The urgency for receiving last rites is portrayed in medieval texts, such as Middle English lyrics about Death. One example can be found in Davies, ed., Medieval English Lyrics, 73: "Now man is whole and sound, / And evil comes into his mind. Then the priest is sent for, / That will ready him for Christ. / After the priest has arrived, / dreadful Death has taken him [Now is mon hol and soint, / And uvel him comit in mund. / Thenne me seint aftir the prest, / That wel con reden him to Crist. / Afteir the prest boit icomin, / The feirliche Deit him havit inomin]." 
parents, and even midwives, were allowed to perform emergency baptisms. In cases of emergency baptisms, the child's head had to be washed, the person performing the baptism had to christen the child in the name of the Father, Son, and Holy Spirt, and it was preferred that the child's name was said aloud. ${ }^{102}$ Concern for a newborn's soul, according to Linda Pollock, also eventually led to the shortened interval between birth and baptism from the twelfth until the fifteenth centuries. ${ }^{103}$

In addition to performing sacraments, women could seek out relics and amulets to protect them and their infants from harm. For example, expectant mothers wore apotropaic rings. Gilchrist provides the example of Margaret Patson (1441), who wore a ring, and also encouraged her husband to wear the ring of Saint Margaret. ${ }^{104}$ Moreover, churches sometimes owned girdles which were supposed to offer protection to women and children, if women laid them on their abdomen before or while giving birth. Girdles were long strips of parchment sewn together that contained scripture, charms, and prayers. ${ }^{105}$ Sometimes girdles were passed down in a family, while others sought more famous relics. The girdle of the Virgin Mary, also known as "Our Lady’s Girdle," at Westminster Abbey was loaned to pregnant women in the royal family. It was sent to

102 Orme, Medieval Children, 25-26.

${ }^{103}$ Linda Pollock, Forgotten Children: Parent-Child Relations from 1500-1900 (Cambridge: Cambridge University Press, 1983), 268-269.

${ }^{104}$ Gilchrist, Medieval Life, 138; Also, Carole Rawcliffe, "Women, Childbirth and Religion in Medieval England," in Women and Religion in Medieval England, ed. Diana Wood (Oxford: Oxbow Books, 2003), 101.

105 Paula Rieder, "Pregnancy and Childbirth: Christian Women," in Women and Gender in Medieval Europe: An Encyclopedia ed., Margaret Schaus (New York: Routledge, 2006), 505. 
Eleanor of Provence in Gascony, to the market town of Knaresborough for Edward I's daughter Elizabeth, and to Queen Elizabeth of York in 1502. It was later destroyed in 1535, when church reformers disapproved of childrearing relics. ${ }^{106}$ The girdle of Mary was supposed to represent the idea that the holy mother would act as an intercessor if the birthing process went awry.

Scrolls and mineral stones were also used to prevent danger in childbirth. Scrolls made of parchment paper containing images of the Cross or wounds of Christ, and jasper, rock crystal, and eaglestone, were laid on women's stomachs during the birthing process. ${ }^{107}$ Women who did not have access to relics, prayed to local or patron saints of pregnant women like Saint Margaret or Saint Dorothy. In the miracle stories in the paternal grief chapter, some families even called upon help from Thomas of Becket. Women also vowed to go on pilgrimage to a saint's shrine in exchange for a healthy birthing experience.

Children who survived child death could still fall victim to dangers postpartum. Dangers leading to child death were lurking around every corner of the medieval household and community. A Middle English lullaby highlights this particular sentiment. In an anonymous fourteenth-century lullaby, the lyricist depicts a mother singing to her child:

${ }^{106}$ Orme, Medieval Children, 16-18; Joseph Gwara and Mary Morse contend that the only surviving English birthing girdle is a 1534/1535 strip of paper attributed to the printer Wynkyn de Worde. See "A Birth Girdle Printed by Wynkyn de Worde," The Library: The Transactions of the Bibliographical Society 13, no. 1 (2012): 33-62.

${ }^{107}$ Curt Bühler, "Prayers and Charms in Certain Middle English Scrolls," Speculum 39, no. 2 (1964): 270-8. 
Child, you are a pilgrim born in sin: / you wander in this treacherous world, look ahead! / Death is hiding around a dark corner [Deth shall come with a blast, ute of a well dime horre], / with a gust to cast down the kin of Adam as he has done before... / Child...your days are numbered, your travels planned, / whichever way you go, north or east, / Death shall happen to you with bitter misery [bitter bale] in your breast. ${ }^{108}$

In the verses, "death" is portrayed as a force that can quickly take children away from the physical ream. It hides around every corner. No matter where one goes, death will be there, lying in wait. In the last line, the author emphasizes the misery surrounding death. Death for the child, and those around the child, is a tragic, painful event.

In medieval England, both fathers and mothers, and even godparents, were considered liable, by religious officials, for a child's safety, especially during the fragile moments leading up to baptism and until the child could avoid accidents on their own. This is why, during the baptismal ceremony, parish priests encouraged parents to keep children away from animals, water, and fire until about the age of seven. If parents did not do this, godparents were to take on this responsibility. ${ }^{109}$ This request was not made in private, but announced aloud, in front of all the attendees, making it clear that a child's safety was important.

${ }^{108}$ Davies, ed., Medieval English Lyrics, 107, Lines 25-28, 31-34: "Child, thou ert a pilgrim in wikedness ibor: / Thou wandrest in this fals world-thou lok thee befor! / Deth shall come with a blast, ute of a well dime horre, / Adames kin dun to cast, himsilf hath ido befor...Child, thy dawes beth itold, thy jurneys beth icest. / Whoder thou shalt wend, north other est, / Deth thee shall betide with bitter bale in brest."

${ }^{109}$ Orme, Medieval Children, 29. 
Walter of Bibbesworth, a thirteenth-century English poet, called for even more vigilant guardianship during the early stages of childhood in his Le Tretiz (The Treatise). Le Tretiz is an Anglo-Norman poem used for the instruction of French, since both French and Latin were the standard languages of record in England during the thirteenth century. While used as a language book, Walter of Bibbesworth notes the hazards of childhood, and puts forth ideas on how to avoid accidents. He writes:

When the infant is born at last, / Cover it with swaddling cloths. / Put it in a cradle gently / And have a child's nurse rock it often. / The child will first start to crawl, Because they are not able to walk at all. / They dribble all over, / making messes on their clothes, / so the nurse, who has extra clothes, must provide a bib for the child to wear./ When they start to walk, / they get dirty and can get hurt anywhere. / For this reason, have a young servant follow them so that they do not stumble on the floor. ${ }^{110}$

Walter of Bibbesworth explains that children must be swaddled right after birth, hinting that this could help prevent crib deaths. For Walter of Bibbesworth, though, children learning to walk is one of the most dangerous situations. He encourages guardians to go beyond making sure that children avoid hazards when they are with them. Once children are able to walk, he says, they can get into all sorts of trouble. Because of this, guardians

${ }^{110}$ Walter of Bibbesworth, Le Tretiz, ed. William Rothwell (London: Anglo-Norman Text Society, 1990), Lines 5-19: "E quant li emfez serra neez / Coveint k'ill seit maylolez, / Puis en berce le cochez / $\mathrm{E}$ de une bercere vous purveez. / Le enfant commence a chatener / Einz k'il sache a peez aler; / E quant il baave de nature, / Pur ces dras sauver de baavure; / Dites dount a sa bercere/ Ke ele lui face une baavere / E quant commence de aler / De tay se veet espalier, / E pur maine e pur blesure/ Garszoun ou grace li deit suire, / Qui'il ne cece ne ne chece.” See also Nicholas Orme, Fleas, Flies, and Friars: Children's Poetry from the Middle Ages (Ithaca: Cornell University Press, 2011), 9. Orme provides the English translation of this poem on children. 
should employ servants (or someone on hand) to walk behind children, so that injury does not occur.

Handbooks for priests, such as the Oculus Sacerdotis, compiled by William of Pagula in 1320, also included parenting advice. The Oculus Sacerdotis not only contained sections devoted to a child's incorporation into the spiritual community, such as details about the rites of baptism and confirmation, but also covered important childrearing topics, such as how to avoid overlying and swaddling mishaps. ${ }^{111}$ This concern for child safety is not only represented in the medieval textual evidence of the time, but also in images from illuminated manuscript.

In a sixteenth century French book of hours (MS Douce 276, fol. 110b recto), an example of "baby-proofing" the pre-modern home in the form of a wooden-framed walker for infants can be seen. In the picture, a woman and five children gather around the fireplace, the center of the household. In front of the fireplace, one child tends to the fire, while a woman cradles a swaddled infant in her lap. Two other children sit in the left half portion of the image, one in a chair and the other on the floor next to a dog. To the right of the woman, a fifth child holds himself up in a framed walker, watching the activity unfold in the main room of the house. His walker has a box-frame with four wheels at the bottom. Walkers such as this not only enabled children to stand upright to practice their walking skills but were also used as a mechanism for children to stabilize themselves, so that they would not fall into fire or other hazards around the home.

${ }^{111}$ Orme, Medieval Children, 66-67. 
Walkers also made it easier for children to avoid altercations with animals that ended up inside the house. ${ }^{112}$

Despite the many warnings that were given by members of the clergy or how many precautions were taken by supervisors of children, deaths still occurred around the household. Accidental deaths around the medieval home contributed to the high death counts of children. Descriptions of accidental deaths are scattered throughout miracle stories, as will be seen in the following three chapters. Coroners' rolls provide additional information about child deaths in medieval communities. Hanawalt uses coroners' rolls to reconstruct daily life in medieval peasant communities. According to Hanwalt, medieval peasant households were at the heart of village life. ${ }^{113}$ Peasants held a share of arable land that served as their livelihood, as well as access to meadowland, pastures, and woodland that delineated the perimeters of the village. ${ }^{114}$ Every village had a parish church and cluster of crofts. ${ }^{115}$ A croft, which was an enclosed (by hedges or ditches) area of land,

\footnotetext{
${ }^{112}$ No barred walkers survive from the Middle Ages. Some seventeenth- and eighteenthcentury walkers are on display at the Museum of London and the Victoria and Albert Museum of Childhood.

${ }^{113}$ Hanawalt, The Ties That Bound, 21. Village lands were divided into sections, with enclosures at the center that included peasants' houses, gardens, and outbuildings. Fields and meadow lie outside the cluster of houses, and woodland surrounded the village perimeter. By the thirteenth century, population growth had forced some village boundaries to push up against others, which resulted in annual attempts to define boundaries; See Brian Roberts, Rural Settlement in Britain, Studies in Historical Geography (Kent: Dawson \& Sons LTD, 1977), 87-88.

${ }^{114}$ Hanawalt, The Ties That Bound, 23. Hanawalt shows that competition to make a livelihood from arable lands was strong. Court verdicts and coroners' inquests show that disputes over boundaries lead to physical and verbal fights, and sometimes even death.

115 Jeffrey Singman, Daily Life in Elizabethan England (Westport: Greenwood Press, 1995), 84.
} 
surrounded the toft (i.e., the location of the home), household well, barn, garden, and other buildings belonging to a family. ${ }^{116}$ According to Hanawalt, a family's life was centered around the croft and toft. It was here where "families kept their worldly goods, cared for their animals, raised their children, and entertained their friends." ${ }^{\prime 17}$

Household types on village crofts could vary. The smallest house was that of the cottar's household. Hanawalt explains that these houses were either one-room houses (sixteen by twelve feet), or two-room houses (thirty-three by thirteen feet). Long-houses were more common on the village landscape. Some could be only a little larger than cottages, while others could be anywhere from forty-nine to ninety-eight feet long, with the former being more common. They contained living quarters at one end and a byre, or room that sheltered animals, which was separated by a passage, at the other. Timber was used to frame houses, while wattle and daub was used to fill in the timber walls. Roofs were thatched with straw and clay with pieces of straw usually lined the floors. ${ }^{118}$

Inside the home, the hearth was located in the main room and was at the center of household activity. Meals would be prepared over the hearth's open flames, and families would gather around the hearth to socialize and take in its warmth. Families may have also slept in the main room by the hearth, especially in one-room households and when cold weather persisted. Multi-room houses had chambers, or rooms branching out from the main room. Chambers could be used for sleeping or storage. In Medieval Domesticity:

\footnotetext{
${ }^{116}$ Hanawalt, The Ties That Bound, 23.

${ }^{117}$ Hanawalt, The Ties That Bound, 23.

${ }^{118}$ Hanawalt, The Ties That Bound, 33-35.
} 
Home, Housing and the Household in Medieval England, Sarah Rees Jones points out that chambers could also be used as meeting areas, to discuss matters of the household. ${ }^{119}$

Because the hearth was the center of activity in the domestic sphere, many accidents happened around the structure. ${ }^{120}$ Legal texts reveal that because hearths were essentially open fire pits, they were the source of most house fires. Hearth fires spread quickly throughout peasant houses because they were made out of wattle and daub, and floors covered with straw. In addition to causing devastating house fires that killed both children and adults, infants left unattended in their cradles near the hearth could sustain injuries (or die) if chickens pecked around the hearth for food and dropped burning straw into their cradles. There are even instances where boiling liquid fell onto children when the stands holding pots over the hearth broke and tipped over. ${ }^{121}$

Children also encountered dangers either while their parents performed chores or while they participated in errands themselves. According to Hanawalt, infants and toddlers could not contribute to household chores and were therefore "a drain on the time of the housewife." 122 Even though infants and toddlers could not help much with chores, they could still fall victim to accidents while their parents performed tasks or while

\footnotetext{
${ }^{119}$ Hanawalt, The Ties That Bound, 39; See Jeremy Goldberg and Maryanne Kowaleski, eds., Medieval Domesticity: Home, Housing and Household in Medieval England (Cambridge: Cambridge University Press, 2008), 38.

${ }^{120}$ Hanawalt, The Ties that Bound, 157-158.

${ }^{121}$ Hanawalt, The Ties that Bound, 40, 175.

${ }^{122}$ Hanawalt, The Ties That Bound, 157.
} 
"playing" at these tasks as their parents worked. ${ }^{123}$ One example of a child death occurring while a mother was performing chores is found in a miracle story associated with Thomas of Cantilupe. A mother named Sybil left her sixteen-week-old daughter alone while she went outside to shear sheep early in the morning. While unattended, the infant managed to wiggle out of her swaddling bands, fall out of her cradle with the bands still wrapped around her body, and died. The baby remained hanging (pendentem) from the cradle until Sybil discovered her motionless body much later that morning. Sybil shed tears (lacrimas) for the child, and invoked the help of the saint. ${ }^{124}$ While Sybil's long absence from the home may appear shocking to our modern eyes, it would have probably been a common occurrence in daily life because of all the work that needed to be done around the medieval household. Medieval mothers would have worked exhausting schedules in order to keep the economy of the household running, because families were not usually extended with female kin to help. Women were responsible for the running of the household, rearing of offspring, and a variety of other occupations. Spinning in particular was a common activity. Cloth was sold to weavers or used to make clothes and sheets for a family. Women also did laundry, brewed, helped in the fields, tended to animals, collected nuts and firewood, and participated in the back-breaking task of picking up stray grain. ${ }^{125}$ One source that can give us a glimpse into the heavy

\footnotetext{
${ }^{123}$ Hanawalt, The Ties That Bound, 157. Out of the 2,837 cases in coroners' records that Hanawalt considers, $17.2 \%$ of children died while being around mothers who were performing chores.

${ }^{124}$ Jean Bolland et al., Acta Sanctorum (Paris: Society of Jesuit Theology, 1865), October 1, Section 643-644, 644.

${ }^{125}$ Hanawalt, The Ties that Bound, 147-149.
} 
workload of peasant women is the fifteenth-century poem, the Ballad of a Tyrannical Husband. The poem consists of an argument between a husband and wife about who is the hardest worker between the two. Angrily, the husband scolds his spouse, saying that instead of having food ready for him after she finishes her easy chores, she spends most of her time at the neighbor's house, where she "syttes ther janglynge with Jake an with John," or "sits their chatting with Jake and Joan." ${ }^{126}$ The narrator interjects to point out the fallacy of his statement, writing that "The goodwife had much to do, but she has no servant, / Many small children to look after, not just herself alone, / She did more than she could inside her own house." ${ }^{27}$ The wife then goes on to give a long list of all the tasks that she must perform in a day in order to keep the house in order and everyone happy.

Once children were older, they attached themselves to their parent of corresponding gender early on and were an important part of the "smooth functioning" of the household and "indispensable part of the household economy." 128 At six years of age, boys started taking on menial tasks, such as gathering items needed for inside the home,

\footnotetext{
126 James Halliwell and Thomas Wright, eds., Reliquiae Antiqua, Vol. 1 (London: John Russell Smith, 1845), 197.

${ }^{127}$ Halliwell and Wright, eds., Reliquice Antiqua, Vol. 1, 196: "The goodwyf hade meche to doo, and servant had se none, / Many smale chyldern to kepe besyd hyrselfe alone, / She dyde more then sho might withyn her owne wone."

${ }^{128}$ Hanawalt, The Ties that Bound, 156, 167. It must be noted that there could be exceptions to the gender-parent attachment. For instance, in a household that had only daughters, female children could be helping their fathers plough fields and separate grain because the economy of the household would depend on it. An example of a young girl helping her father slaughter a pig in Northwood in Chapter Two could be an example of this situation. Children could have also helped parents of the opposite gender with chores if they were not needed by the other parent.
} 
like wood, peat, fruit, and nuts. Boys aged seven and above were given more responsibility. They were ox goaders, tended to animals, and helped separate grain from stalks. Teenagers graduated to helping plough fields, fixing mill wheels, and learning other husbandry skills under the tutelage of their fathers. ${ }^{129}$ Accidental deaths of male children involving outdoor activities such as these are common in court rolls and coroners' records. Boys died from being trapped under tree branches or chunks of soil when collecting items, and from being injured with tools while working in the field with their parents. Herding animals was also a major risk in and of itself. Inquests contain instances of horses trampling boys and of boys falling into ditches and drowning while herding animals away from stables or across bodies of water. ${ }^{130}$

Young girls, on the other hand, did not participate in as many outdoor-related chores compared to boys, at least not until they were older. From the ages of six to twelve, girls contributed to the household economy by attending to siblings and building fires in the home. Once they got older, they played a major role in the collection of food items and food production in general. They gathered apples, cherries, pears, and those living in coastal areas collected shellfish. Despite the fact that female children, for the most part, did not participate in the same tasks as male children early on, they still were involved in fatal accidents while working around the home with their mothers. Most accidental deaths involving young girls occurred while helping their mothers prepare meals or laundry. Girls fell into wells, located in the croft while, retrieving water or

${ }^{129}$ Hanawalt, The Ties that Bound, 157-158.

${ }^{130}$ Hanawalt, The Ties that Bound, 158-159. 
perished after falling into boiling pots of liquid used for laundry or cooking. ${ }^{131}$ Waterrelated accidents were the leading cause of child death, for both male and female children and several examples are mentioned in the miracle stories given in the following chapters. Both female and male children were also run over by carts and ploughs and got impaled by farm tools while working and playing. ${ }^{132}$

The community layout of cities differed much from that of rural communities. Residents of cities lived in crowded street-side houses or rented rooms next to the workshops of craftsmen, which says a lot about each entitie's mode of existence. City dwellers relied on trade, while villagers focused on agriculture. In London, some people lived within the shops that they worked, or rented rooms in small buildings from parish churches, while wealthier merchants lived in larger houses with courtyards. Multi-story houses were common in the fourteenth and fifteenth centuries. ${ }^{133}$ Villagers entering cities would have been overwhelmed by the crowded streets. London had a population upward of 60,000 people, whereas some villages only had 200 or less. ${ }^{134}$ They would have also been "struck by the height and density of the houses...To someone used to low building scattered about closes in peasant villages, the London streets must have felt like canyons, with their overhanging buildings and a forest of signs spreading over them horizontally like tree branches." ${ }^{" 135}$

\footnotetext{
${ }^{131}$ Hanawalt, The Ties that Bound, 157-158.

${ }^{132}$ Ronald Finucane, Miracles and Pilgrims: Popular Beliefs in Medieval England (Totowa: Rowman and Littlefield, 1977), 110.

${ }^{133}$ Hanawalt, Growing Up in Medieval London, 24-26, 29.

${ }^{134}$ Hanawalt, Growing Up in Medieval London, 24.

${ }^{135}$ Hanawalt, Growing Up in Medieval London, 25.
} 
Just as in villages, cities could prove dangerous for children. Deaths could happen while playing or performing everyday activities. In an inquest from 1324, for instance, Johanna, the daughter of John Cotekyn, perished when she fell down a flight of stairs in her home. ${ }^{136}$ Petronilla, the daughter of William de Wyntonia, suffered a particularly painful death. While she was outside playing in the street in 1301, a horse walking by kicked her right side. She lived for a day, but eventually succumbed to her injuries. ${ }^{137} \mathrm{In}$ another inquest, a coroner from the city of London recorded an animal-related death caused by a sow that had entered a building. He reports that in 1322, on the Friday after the Feast of Saint Dunstan, Johanna, the one-month-old daughter of Margaret and Bernard de Irlaunde was left unattended in her cradle at a shop in the parish of Saint Michael. While her parents were conducting business with another member of the community, a sow entered the shop and bit the right side of Johanna's head. Her mother was able to keep her alive until midnight of the same day, but the baby ultimately died from the head wound. ${ }^{138}$ In a freak accident, a bear, which was being housed at an inn in Salisbury, broke free of its chains and killed a seven-year-old girl named Emma. ${ }^{139}$

Disease and illness in villages and cities also contributed to the high death counts of children. While coroners' inquests do not always contain detailed information about disease, miracle stories sometimes contain examples of the types of illnesses which

\footnotetext{
${ }^{136}$ Reginald Sharpe, ed., Calendar of Coroners Rolls of the City of London A. D. 13001378 (London: Richard Clay and Sons, Limited, 1913), 92-93.

${ }^{137}$ Sharpe, ed., Calendar of Coroners Rolls, 30-31.

${ }^{138}$ Sharpe, ed., Calendar of Coroners Rolls, 56-57.

${ }^{139}$ Hanawalt, The Ties That Bound, 38-39.
} 
children suffered. Children died from complications with bodily organs, seizures, tumors, and fever. The Black Death, as mentioned beforehand, also produced causalities, even though the sources under investigation in this project do not mention plague, or symptoms of plague such as fever or the appearance of buboes.

Children in both cities and villages could also be abandoned and left for dead or killed by their parents. Families not able to support more children may have killed offspring or abandoned them after birth. Although cases of infanticide and abandonment were recorded, John Boswell argues that there are fewer cases than one would expect and that when parents abandoned their children, they usually hoped that someone who could properly provide for them would find them, not that they would die. ${ }^{140}$

Medieval texts indicate that people tried to revive children when they were victims of accidents and illnesses. They suspended them from their feet to drain water from their mouths when they drowned, they poked them to wake them up from unconsciousness, and performed religious acts in attempts to save them. Gordon explains that bending a penny and measuring children for a saint are "two peculiarly English rituals [that] often accompanied the invocation [of saints] and served as emergency, medicine-enhancing prayer." ${ }^{141}$ Bending a penny involved a petitioner holding a coin above an injured child and asking for holy intervention of a saint. The petitioner was then supposed to take the penny to the saint's shrine as a gift/donation. This ritual was also used on adults and animals. Measuring someone for a saint, on the other hand, is a reference that can be found in sixth-century sources from Europe, but the practice became

${ }^{140}$ Boswell, The Kindness of Strangers.

${ }^{141}$ Gordon, “Accidents Among Medieval Children,” 150. 
particularly popular in the twelfth and thirteenth centuries in England. It is widespread in English miracle stories, especially the Simon de Montfort collection. The ritual act involved measuring the length and height of a person's outstretched arms with a string, which would later be used for a votive candle or to determine how many votive candles would be lit on the person's behalf. ${ }^{142}$ In miracle stories, these acts, according to the authors of the texts, usually were successful.

Although both parents were liable for the safety of children, mothers could be accused of foul play if children died under their care, especially if they did not follow legal protocol after their offspring perished. When children perished, community members and relatives tried to revive them and if they were not able to, they would attempt to confirm death. In miracle stories, children are suspended by their feet when they drowned, in hopes that water would drain from their bodies. Others were poked in order to see if they showed signs of life. If death was confirmed, children who died, whether by natural causes, foul play, or an accident, it was the first-finder's duty, no matter their relation to the victim or age, to "raise the hue and cry" and report the incident to the local coroner. ${ }^{143}$ The office of the coroner was first established in 1194, when the justices in eyre elected three knights and one clerk in every county to be "keepers of the pleas of the crown." 144 Those elected to the office of coroner were of the knightly class

\footnotetext{
${ }^{142}$ Gordon, “Accidents Among Medieval Children,” 151.

${ }^{143}$ The first-finder was not necessarily the person that first found a dead body, but rather the first person to report the death to authorities.

${ }^{144}$ Roy Hunnisett, The Medieval Coroner, Cambridge Studies in English Legal History (Cambridge: Cambridge University Press, 1961), 1: Praeterea in quolibet comitatu eligantur tres milites et unus clericus custodies placitorum coronae; See William Stubbs, ed., Select Charters and Other Illustrations of English Constitutional History, revised by Davis Carless (Oxford: The Clarendon Press, 1913), 254. Hunnisett points out that the
} 
(or just below) because it was required that they be substantial landowners. ${ }^{145}$ Coroners were required to perform a wide range of administrative and inquisitorial duties, both alone and with the sheriff. There were certain "crown pleas" that were strictly allocated to the coroner, such as holding inquests upon dead bodies, hearing appeals and confessions, and attending county court hearings. ${ }^{146}$

Roy Hunnisett contends that conducting inquests upon dead bodies was the duty most performed by the medieval coroner. Members of medieval communities played active roles in the death-investigation process and served as crucial informants to coroners. It was the responsibility of the "bailiff or the lawful men of the neighbourhood" to summon the coroner, notify the closest three neighbors of the death, and guard the

formal title of custos placitorum corone was used throughout the Middle Ages, but a shorter form, coronaries, which was confined to a short-period around 1200, and then coronator became widespread.

${ }^{145}$ Hunnisett, The Medieval Coroner, 150, 174-175. Coroners were usually elected either in front of royal justices or in the county courts, but in rare circumstances, the position was hereditary. The reason why coroners were required to be land holders is not clearly noted in legal texts. Hunnisett suggests that sufficient land was needed to supplement the expenses that coroners encountered while performing their duties.

${ }^{146}$ Hunnisett, The Medieval Coroner, 1-2. Even though the office of the coroner was officially established in 1194, the specific role of the coroner was not solidified until at least 1250 . Additionally, the duties of the coroner were not new before the late twelfth century, but were being performed by other types of officials before the office was created. During the reign of Henry I, the county justiciar, who could both keep and determine the crown pleas, assumed the duties of a coroner. Henry II discontinued the county justiciar office because the justiciar became too powerful and the duties of holding inquests and hearing appeals fell on hundred and wapentake serjeants instead. While the office of the hundred serjeant survived under the sheriff throughout the Middle Ages, they had much less power than the coroners of 1194 in that they could not attach suspects to a crime outside of their hundred, and had no connections with appeals and outlawries in the county court. Coroners, on the other hand, could attach or arrest witnesses and suspects, and even appraise and safeguard land and goods that might be forfeited. After 1225, it was a punishable offence for a hundred serjeant to perform the coroner's duties, 1-3, 193. 
body.$^{147}$ Moving or burying a body before it was properly investigated was a punishable offence, and people often went to great lengths to keep a corpse isolated until a coroner arrived at the scene. In Devon, for instance, a coroner was delayed eight days from seeing a body, so a hedge was built around it in order to ensure that it remained untouched. ${ }^{148}$ Coroners were required to immediately travel to a body upon hearing the summons. In reality, arrival time varied according to the number of coroners in a particular county and the distance needed to travel to reach the deceased. In article twenty of the 1194 eyre, every county was required to have four coroners, but this statute was not always executed. The number of coroners in each county varied from century-to-century and county-to-county. In the 1246, Sussex had only one coroner, but between 1255 and 1262 it had two, and three between 1275 and 1279. Yorkshire and Kent, on the other hand, had five coroners throughout the thirteenth century, because of their sizes, and the ways in which their counties were divided (Kent was divided into five lathes and as a result had five coroners for each lathe). ${ }^{149}$

Upon receiving notice that a death had occurred, coroners ordered bailiffs or sheriffs to assemble a jury of men from four or more neighboring townships. The coroner would swear them in and they would inspect the body. Next, the coroner and his jury would listen to testimonies from witnesses, before deciding on a verdict. ${ }^{150}$ If medieval

${ }^{147}$ Hunnisett, The Medieval Coroner, 9-11; Orme, Medieval Childhood, 99.

${ }^{148}$ Hunnisett, The Medieval Coroner, 11.

${ }^{149}$ Hunnisett, The Medieval Coroner, 134-135.

${ }^{150}$ Jurors would have most likely known people in the towns that they were investigating and there are some cases where they issued lenient penalties and even covered up crimes. For example, they could appraise an item that was going to be forfeited for much less than what it was actually worth so that people would not lose too much money. In other 
people did not report a crime to local authorities, they could be fined or even become a suspect for the coroner and jury to investigate further. Those convicted of homicide had to forfeit all of their chattels and moveable property to the king's treasury. Families of those who committed the act of felo de se, or suicide, risked losing their property and the right to bury their deceased loved one inside of a parish cemetery. In contrast, when people died from accidental deaths, the "thing" (i.e., an object or animal) that caused the accident was supposed to be forfeited to the king as a deodand, or "gift to God."151

If neglect was believed to be a contributor to the accidental death of a child, members of a community, including coroners and jurors, worked together in order to punish the relatives of a child. In one London inquest, for example, a coroner reported that the one-year-old son of Ralph Peion of Wotton, Richard, fell on a pair of gardening shears and slit his throat in 1390 . He ruled this death a suicide. ${ }^{152}$ Butler asserts that it is hard to believe that a medieval jury would be convinced that a "one-year-old boy had set

cases, felonious crimes were completely covered up. In Lincolnshire coroners' rolls, thirty cases of female hangings were ruled accidents rather than suicides. Butler in, "Women, Suicide, and the Jury," 149, posits that these verdicts were made to spare families from financial ruin and the disgrace of suicide. Felonious crimes may have also been omitted from coroners' rolls in order to ensure that families could retain their social standing in a society.

${ }^{151}$ Sharpe, ed., Calendar of Coroners Rolls, xxvi-xxvii; The value of the object causing an accident was usually forfeited to the king, not the object itself and then the money was supposed to be donated to the Church on behalf of person who lost their life. Regulations on what exactly a deodand consisted of were complex, but the general rule was that an object in motion that killed and adult or child, such as a moving cart, was to be forfeited; however, if the cart was stationary and an object fell from the cart and killed someone, then the falling object would be forfeited, not the cart.

${ }^{152}$ Sara Butler, "Degrees of Culpability: Suicide Verdicts, Mercy, and the Jury in Medieval England," Journal of Medieval and Early Modern Studies 36, no. 2 (2006): 263. 
out deliberately and feloniously to kill himself with a pair of shears," especially since deaths of this nature were ruled accidents because the person was considered too young to be conscious of the fact that they were committing suicide. ${ }^{153}$ In other words, there was no clear intention behind the act. Thus, Butler contends, that the only reason that Richard's death was ruled a suicide was so that the community would view the family of the child in a much more negative light because of child neglect. ${ }^{154}$ If Richard's death had just been ruled an instance of infortunia, his parents' negligence would have gone largely unnoticed by the community because they would not have received punishments associated with felonious crimes. A case of a wet nurse fearing she might be accused of neglect is described in a miracle story attributed to Wulfstan of Worcester. In the miracle, a wet nurse (nutrix) leaves an infant untended in a bath and he drowns. Fearing that she will get in trouble for the death, she flees the accident scene (nutrix interim sibi fuga). ${ }^{155}$

Overlaying, a term used to describe a mother or wet nurse accidently falling asleep on and suffocating a child while nursing in bed, was second only to drowning as the most common cause of infant death in England in the thirteenth century. ${ }^{156}$ This type of death was often regarded with suspicion. Women could be convicted of foul play if babies died while co-sleeping, especially in instances when the community perceived that the child was unwanted because a household could not support more children. Wet nurses, too, were accused of purposely killing infants and still receiving pay for nursing,

${ }^{153}$ Butler, "Degrees of Culpability," 263.

${ }^{154}$ Butler, "Degrees of Culpability," 263-264.

${ }^{155}$ Darlington, trans., Vita Wulfstani, 120.

${ }^{156}$ Finucane Miracles and Pilgrims, 109. 
then blaming the death on overlaying. Cases of overlaying usually made their way to ecclesiastical courts, but because common law required juries to report all accidental and felonious deaths, some overlayings can be found in royal records. Richard Helmholz explains that the Church considered overlaying to be a form of accidental death caused by parental negligence. Butler points out that women were not always accused of infanticide or neglect when they overlay their children. She cites a case in the Northamptonshire eyre of 1329-1330. In this case, a woman named Alice overlay her three-week-old daughter, but she was exonerated by the jury even though she fled the scene of the death out of fear. ${ }^{157}$ Because overlaying happened so frequently, English clergymen took steps to prevent it by cautioning women against and attempting to prohibit the act of co-sleeping altogether. ${ }^{158}$ Swaddling accidents could also be looked at with suspicion. Although swaddling methods varied, mothers could be accused of not swaddling their infants properly, which could lead to them falling out of cradles or laps more easily. Swaddling techniques and examples of swaddling deaths will be addressed more thoroughly in the next chapter.

\section{CONCLUSION}

${ }^{157}$ Butler "A Case of Indifference," 67; For a more detailed discussion on the stigma attached to overlaying and for more details about wet nurses accused of overlaying see Schaus, ed. Women and Gender in Medieval Europe, 93 and Richard Helmholz, "And were there children's rights in early modern England? The Canon Law and 'intra-family violence' in England, 1400-1640," The International Journal of Children's Rights 1 (1993): 24.; It should be noted that Boswell, in The Kindness of Strangers, argues that infanticide was less common in the Middle Ages than once suspected; See also Laes and Mustakallio, eds., The Dark Side of Childhood, 3-20.

${ }^{158}$ Finucane Miracles and Pilgrims, 109; See Gordon, "Accidents Among Medieval Children," 154. 
Even though child mortality rates remain uncertain, it is clear that children faced dangers from the time of birth onward in medieval England. Miracle stories and coroners' rolls provide information on types of child death that occurred within communities. Religious authority, parents, and godparents often took strides to shield children from harm, even though illnesses and dangers still lurked around every corner of medieval communities. Women prepared for childbirth with girdles, midwives, and amulets, however, newborns could still be delivered stillborn or perish soon after birth because of complications during delivery. The years surrounding birth could be hazardous for infants as well. Infants could die from overlaying, swaddling accidents, hearth fires, and animal bites that they could not avoid on their own. Those who survived birth and disease still encountered external threats in and around the domestic sphere, despite being placed in barred walkers and working alongside relatives. In villages, performing chores in the croft, alongside siblings and parents, could prove to be deadly. Children died gathering water and food for cooking, helping plough fields, gathering wood, and herding animals. In cities like London, children perished while playing in the streets with friends, falling down stairs, and from animal-related accidents. When death occurred, neighbors and the nearest coroner were called upon the scene. Parents, especially mothers who were deemed responsible for the domestic sphere, could be held accountable for neglect in some cases, such as overlaying. The anxiety over the dangers of childhood are expressed in medieval medical and religious texts, as well as Middle English lyrics and artwork. The emotions of fear, pain, and sadness were often used when describing child death in order to point out its tragic consequence. Now that a brief background on child death has 
been given, Chapter Two will analyze how medieval writers portray mothers as responding to deceased offspring. 


\section{Chapter 2}

\section{"I Should Have, But I Was Blind": Displays of Maternal Grief}

In a miracle story from the Thomas Becket collection, William of Canterbury reports that a five-year-old girl from Northwood was helping her father, Salomon, a weaver, slaughter a pig outside their home. After the chore was completed, her father told her to wash off the blood on her body and clothes in a nearby pool of water (stagnum). ${ }^{159}$ This harmless request would lead to tragedy, because the girl, who was not being supervised at the time, fell into the water and drowned. The girl's father extracted her lifeless body from the water, while her mother, upon hearing the news that her child was dead, went out into the crowd (exiit in publicum) that had gathered around her daughter's corpse, and began weeping and praying (flens et orans). According to William of Canterbury, she proceeded to beg Thomas Becket for divine aid and the girl was eventually resuscitated. ${ }^{160}$ The emotional reaction of the woman from Northwood to the death of her child is typical in accounts of child death in English miracle stories. This chapter will explore accounts of maternal grief associated with child death as recorded by religious men, but will go beyond looking at only miracle stories and consider the emotional language and imagery used in reference to mothers in Middle English lullabies

\footnotetext{
159 The word stagnum in this account could have various meanings. It can refer to a river or stream, or even be a reference to a well, which were often open pits of water in the ground. Communal and private wells were common features in cities, as well as in village crofts. They posed a danger to both adults and children, because the area around them was often muddy and a person could easily slip. Because the body of water is not described in detail in this account, I used a more general description of the term.

${ }^{160}$ William of Canterbury, Materials for the History of Thomas Becket Vol. 1, 366.
} 
and passion lyrics dating to the fourteenth and fifteenth centuries. In addition to analyzing how mothers are depicted as grieving in the written record, the causes of the female grieving process will also be assessed. In order to preserve the flow of the original language and highlight the poignancy of child death within these texts, I do not give word-for-word translations, but rather put forth the sense of what the author was trying to portray.

In this chapter, I demonstrate that a pattern of how and why mothers mourn offspring can be discerned within miracle stories and medieval lyrics. Authors of didactic literature, whether compiling miracles in order to promote a saint's canonization or providing lyrics to parishioners for meditational purposes, represent grief in similar and gendered ways. Mothers were commonly depicted as mourning after children died, and this grief was often public. In miracle accounts, mothers experienced anguish/sadness (dolor), cried out/shouted (clāmor), and entered states of extreme mourning. Maternal grief in miracle stories could be so overwhelming that it resulted in frantic mannerisms, such as women running to their deceased children, and episodes of insanity, where women contemplated self-harm. In medieval lyrics, grief, specifically that of the Virgin Mary, is also expressed through the imagery of copious amounts of mourning (mon/murning). I argue that grief was portrayed in these ways to underscore two main ideas in accounts of mothers and deceased children. First, outwardly expressed maternal grief was employed to stress mother-child bonds. The concept of "motherhood" was an important one in the medieval world. Authors, while showing the deeds of a holy figures, underscored this idea and relayed messages about expectations for motherly love. 
Second, authors utilized the emotion of public grief in their rhetoric to put forth messages about the high expectations that medieval society had for mothers in regard to child care.

Despite the fact that both parents were encouraged to be involved in child safety and the prevention of accidents from occurring as we saw in the first chapter, English clergymen, such as Bartholomew, the Bishop of Exeter (d. 1184), expressed the sentiment that it was mainly the mother's responsibility to protect children from harm around the domestic sphere. In his Penitential, which served as a catalogue of sins and punishments for confessors, he gives the example of a mother putting an infant by the hearth and a father placing a pot of water near the fire. If the water in the pot overflowed and killed the child, Bartholomew claimed that the mother in this situation was ultimately responsible for the death, because she left the child unattended in a dangerous area. For this reason, she should perform penance. ${ }^{161}$ Shahar also points out that fathers also are portrayed as getting angry at mothers when their children were ill because they were not caring for them properly. ${ }^{162}$

The idea that it was the mother's responsibility to care for children may have been perpetuated in religious texts because women were largely in charge of the happenings of the domestic sphere. Additionally, women were often viewed as caretakers, since they took on the roles of midwives, wet nurses, and guardians of the sick. Bartholomeaus Anglicus even commented that the mother's job was to "norische and kepe Pe childe," or

\footnotetext{
${ }^{161}$ Dom Morey, ed., Bartholomew of Exeter, Bishop and Canonist: A Study in the Twelfth Century (Cambridge: Cambridge University Press, 1937), 224.

${ }^{162}$ Shahar, Children in the Middle Ages, 116. She also states that synods in Denmark ruled that mothers were responsible for the deaths of suffocated infants and children that drowned.
} 
"nourish and keep the child." ${ }^{163}$ Herlihy, on the other hand, contends that this attitude towards women was because men were usually much older than their wives. The distance between father and child fostered an environment where mothers were more involved with the lives of children, and therefore responsible for them. However, he was mostly describing medieval families in Italy. ${ }^{164}$ Descriptions of mothers in miracle stories and medieval lyrics fall in line with Bartholomew's reasoning, and the authors use grief to indicate guilt when child care is not conducted properly. In other words, authors employed the emotion of grief in order to stress the idea that mother's experienced guilt when they did not, or could not, protect their children from harm.

Before moving on to the examples of maternal grief, it is significant to note that paternal grief is not absent from medieval texts. Authors also placed fathers in the foreground of emotional child death scenes. It also does not mean that authors never portrayed paternal grief as being public. Like mothers, medieval fathers showed the love that they had for their children through tears and cries of distress. However, as will be seen in Chapter Three, fatherly grief, even when outwardly expressed, assumed a more reticent form, for the most part. Authors of miracle stories portrayed fathers as restraining their sadness in front of witnesses or expressing sorrow through prayer and other acts of religious devotion, such as measuring a child for a saint. In records where fathers did mourn heavily, medieval writers often criticized their immoderate behavior.

\section{MATERNAL LOVE AND GRIEF IN MIRACLE STORIES}

${ }^{163}$ Bartholomeaus Anglicus, On the Properties of Things, 302.

${ }^{164}$ Herlihy, Medieval Households, 130. 
Medieval miracle stories are rich with examples of child death and contain accounts describing accidents and illnesses. Within these accounts, authors often showcase maternal grief. In one story associated with Thomas Becket, William of Canterbury described a woman from Northamptonshire grieving the loss of her seemingly dead son. He writes that, through the mother's mourning and utterings [to Thomas Becket] (lugentem et dicentem), she hoped for divine intervention, so that her son could be revived. ${ }^{165} \mathrm{He}$ also reported a miracle about the events surrounding the death of a ten-year-old boy from the village of Lichfield, who was left unattended by his mother at a mill. According to William of Canterbury, an unnamed child got trapped under a mill-wheel and his head was battered on both sides. The injuries proved fatal. Onlookers reported hearing the cries of the mother (matris clamantis) when she saw his dead body. ${ }^{166}$ In another Thomas Becket miracle, this time authored by Benedict of Peterborough, a mother from Rochester panicked when her son, who is affectionately called little Robert (Rodbertulus) in the account, died in a water-related incident. Robert had been playing by the Medway river with a group of friends, when he slipped into the water and drowned. She ran (Accurrit) to her son, crying out (clamans), "Thomas, glorious martyr of God, return my son to me!"'167 This one cry, Benedict of Peterborough says, was repeated again and again (Hacc vox sola matris resonabat in ore) for everyone

${ }^{165}$ William of Canterbury, Materials for the History of Thomas Becket Vol. 1, 540. Robertson, the editor, notes that this miracle is not complete and that some parts have been omitted, specifically details on the boy's revival. No reason for the omission is given.

166 William of Canterbury, Materials for the History of Thomas Becket Vol. 1, 346-347.

${ }^{167}$ Benedict of Peterborough., Materials for the History of Thomas Becket Vol. 2, 226227: "Martyr Dei Thoma gloriose, redde mihi filium meum!" 
to hear. ${ }^{168}$ In a Wulfstan miracle about a boy succumbing to a grave illness, a mother cried out and groaned strongly (clamore valido ingemuit), which prompted fellow community members to gather and shed tears together (populumque collacrimari). ${ }^{169} \mathrm{In}$ another miracle from the same collection, a mother found her son floating in a well (puteum) in Droitwitch, a town in northern Worcester. She pulled the boy out of the well and his limbs were as blue as lead (livida sicut plumbum). ${ }^{170}$ Grieving and anxious (dolens et anxia), and not knowing how to save him, she cried out in despair. The ears of all the neighbors were filled with the horrible cry (horribili clamore replevit aures tocius vicinie) ${ }^{171}$

Maternal grief is also noted in miracles attributed to Thomas of Cantilupe and Henry VI. An anonymous author writes that in 1307, Katerina, the wife of John Tailor, told papal commissioners that in July, she had been walking through the streets of London and overheard bitter tears (amare lacrimentem) coming from the home of her neighbors, Alice and Ralph the goldsmith. Upon entering their home to see the cause of the commotion, Katerina found Alice holding up her eighteen-month-old son Gilbert and shouting that her infant was dead. While the women of the house were conducting chores, Gilbert had wandered outside and drowned in a container (vas) used to collect

${ }^{168}$ Benedict of Peterborough, Materials for the History of Thomas Becket Vol. 2, 227.

${ }^{169}$ Darlington, trans., Vita Wulfstani, 121.

170 The word livida literally translates to "a blue color," but in this case probably refers to the dark bruising/discoloration of the deceased child.

${ }^{171}$ Darlington, trans., Vita Wulfstani, 160. 
rainwater. ${ }^{172}$ In another miracle, this one associated with Henry VI, a woman from Stoneley went outside to work in the fields, while her two-year-old daughter, Agnes, slept alone inside their home. A fire started somewhere in the village and the house caught on fire with Agnes still inside. People started to gather around the house and the woman, thinking that her daughter was dying in the flames, became frenzied (amenciam) because of her sadness. She shouted: "My sweet infant! Alas, I am miserable! O fruit of my womb dying in the fiery grave!" ${ }^{173}$ Suddenly, the mother heard her child yell, "Mamme, Mamme!" Hearing this, the woman ran into the house, despite the large flames, and retrieved the child, who was uninjured because of divine protection from Henry VI. ${ }^{174}$

In each miracle account, the authors not only emphasize the details about the child deaths, but also the emotional responses of mothers to their deceased loved ones. Anne Bailey argues that depictions of female mourning such as this are not an act exclusive to the Middle Ages, but rather represent a characteristic of the trope of ritual lamentation that can be observed in sources dating back to ancient Greece. She adds that medieval hagiography is "full of suppliants appealing to a saint through the ritual language of lament...the most vociferous of these lamenters are women." 175 The reason for this, Bailey contends, is because women were associated with mourning rituals and usually

${ }^{172}$ Finucane, The Rescue of the Innocents, 50.

${ }^{173}$ Grosjean, ed., Henry VI, 94: "mi nate dulcissime! Ei heu me miseram! O fructus uteri mei sic rogis adustus deperiit!"

${ }^{174}$ Grosjean, ed., Henry VI, 94.

${ }^{175}$ Anne Bailey, "Lamentation Motifs in Medieval Hagiography," Gender and History 25, no. 3 (2013): 530 . 
held "custody of the dead." ${ }^{176}$ In the Middle Ages, women were primarily in charge of taking care of the ill and preparing the dead for burial. The preparation of the body for interment took place in the home. Women washed the corpse, wrapped the body in a shroud, and when a woman perished, they joined the procession of the body to the parish churchyard. They also organized ritual mourning, both before burial and at the grave. Ritual lamentation typically involved showing outward signs of grief and could include loudly lamenting or tearing off hair from one's head. ${ }^{177}$ Katherine Goodland contends that women were also believed to be more susceptible to grieving. In humoral theory, women's bodies were described as being cold and wet, which could leave them open to fluid imbalances that caused melancholy. They were also viewed as being more permeable, and therefore more prone to weeping. ${ }^{178}$

I argue that the authors of the miracles go beyond simply describing women as grieving because they were associated with death and lamentation rituals. Instead, the emotional discourse and imagery associated with child death in the above accounts verifies that religious men expected women to have strong mother-child relationships. The concept of "motherhood" was special in the medieval world. Communities

\footnotetext{
${ }^{176}$ Bailey, "Lamentation Motifs," 530.

${ }^{177}$ Sara Butler, Forensic Medicine and Death Investigation in Medieval England (New York: Routledge, 2015), 161; See also Katherine French, The Good Women of the Parish: Gender and Religion after the Black Death (Philadelphia: University of Pennsylvania Press, 2008) 71-72; Also, Elisabeth van Houts "Death, Mourning and Commemoration," in Schaus, ed., Women and Gender, 194.

${ }^{178}$ Katherine Goodland, Female Mourning in Medieval and Renaissance English Drama: From the Raising of Lazarus to King Lear (Hampshire: Ashgate Publishing Limited, 2005), 31 .
} 
celebrated childbirth and marked motherhood with special apparel. ${ }^{179}$ Mothers would have been expected to have strong bonds with their children in order to emulate holy mothers, specifically the paragon of motherhood, the Virgin Mary. Leslie Smith agrees with this idea, stating that women would have looked to religious discourse in order to understand their duties as mothers. ${ }^{180}$

The mothers from Lichfield, Northamptonshire, Rochester, Stoneley, London, Droitwitch, and the unnamed location in Worcester (the second to last miracle attributed to Wulfstan), show love and concern for their children through public maternal grief. The authors depict all of the women as outwardly expressing emotion. They cry out in distress and utter pleas for divine help while mourning. In addition, in six out of the seven miracles, these cries are so loud that they attract the attention of others. These outward cries reinforce the idea that women were emotionally attached to their children and therefore were consumed by grief when the idea of losing them became a reality. The miracle about Agnes is Stoneley demonstrates this argument well. Although Agnes never died in the house fire, her mother believed that she perished and went mad with grief in front of villagers as she thinks about the daughter, who she carried in her womb, burning in the flames. This miracle resembles a coroners' report from Oxfordshire. Adam de Spalding reported that in the year 1298 Alice Trivaler lit a candle by some straw in a

${ }^{179}$ Gilchrist, Medieval Life, 96. Gilchrist explains that a woman's transition into motherhood would have been marked by a new "social skin," meaning special clothing and accessories. Mothers wore white veils for churching and special clothing that would allow her to breast-feed more easily.

${ }^{180}$ Conrad Leyser and Leslie Smith, eds., Motherhood, Religion, and Society in Medieval Europe, 400-1400: Essays Presented to Henrietta Leyser (London: Routledge, 2011), xiv; See also Anneke Mulder-Baker, ed., Sanctity and Motherhood: Essays on Holy Mothers in the Middle Ages (New York: Garland Publishing, Inc., 1995), 303-304. 
shop where her family resided and the straw caught on fire. Realizing that her twentyweek-old son, Roger, was trapped in the fire, Alice shrieked and jumped back into the shop to save him, but they both perished in the smoke. ${ }^{181}$ Although the legal report does not end as happily as the miracle account, both reports demonstrate a mother's love for her child, and the fact that they were willing to lose their own lives in order to save their children.

Side effects of grief, such as frantic acts, madness, and the feeling of helplessness are also included in some of the accounts to highlight the idea of strong mother-child bonds. For instance, the mother from Rochester runs towards her deceased child and repeats her pleas for divine help in front of the community, not willing to give up hope that her child can be restored. On the other hand, the mother from Stoneley undergoes an episode of frenzy when she realizes that her child is in a burning house. ${ }^{182}$ It is also

${ }^{181}$ Herbert Salter, ed., Records of Medieval Oxford: Coroners' Inquests, the Walls of Oxford, Etc. (Oxford: The Oxford Chronicle Company, LTD, 1912), 7-8.

182 Overwhelming maternal grief can also be seen in accounts of royal child death. Matthew Paris, a monk at St. Albans and friend of Henry III, devoted a section of his Chronica Majora (Major Chronicle) to the poignant events surrounding the death of Henry III and Eleanor of Provence's daughter, Katherine. Katherine, the fifth child of Henry and Eleanor, was only three when she died, and the exact cause of her death are unknown. Matthew Paris reports, "Around the discovery of the sacred Cross, the daughter of the Lord King, Katherine, died, mute and helpless, but very beautiful in appearance. Moreover, the queen, her mother, fell ill with grief for which there was no remedy. She could not find comfort in medicine nor in human consolation [Et circa Inventionem sanctæ Crucis, obiit filia domini Regis Katerina, muta et inutilis, sed facie pulcherrima. Regina autem mater ejus dolore concepto infirmitate quasi irremediabiliter occupabature, nec potuit ei phisica vel humana consolatio suffragari]." Matthew Paris paints a picture of extreme suffering on the part of Katherine's mother. Eleanor, like the mothers in the miracle stories mourns over the loss of her daughter publically. So much so that she becomes physically ill and is not able to be cured from her sadness by medicine or human comfort. See Matthew Paris, Matthaei Parisiensis Chronica Majora, Vol. 5, ed. Henry Luard (Cambridge: Cambridge University Press, 1880), 632. 
worthwhile to note that five out of seven of these public grief accounts describe children dying in instances of lack of parental supervision. The woman in Lichfield is not supervising her son when he gets trapped in the mill wheel. Agnes' mother is outside when her daughter is caught in the fire. The woman in Worcester is not by her son when he falls into the well. Alice is performing chores when her son falls into the container of rainwater, and while the author does not disclose the location of the woman by the Medway River, it is suggested that she is not near her son when he drowns because she has to run towards his body. While the authors do not overtly state that the mothers feel guilt because they were not supervising their children, their public grief could point to not only the love they had for their children, but also the guilt they felt for not being there to protect them from harm. The following discussion will focus on more overt examples of authors applying blame to women who did not shield their children from the danger of death.

\section{MATERNAL GUILT AND GRIEF IN MIRACLE STORIES}

In addition to highlighting mother-child bonds, authors also used the idea of public grief to put forth expectations about child care in miracle stories. An example of this can be seen when taking a closer look at the Thomas of Becket miracle about the five-year-old girl from Northwood mentioned in the introduction to this chapter. When the mother (materfamilias) of the girl arrived at the death scene, she began weeping and praying (flens et orans). William of Canterbury goes on to say that she called upon Thomas Becket for help. She pleads, 
Return my daughter to me, Martyr Thomas! If anyone is the cause of this incident, her mother alone must bear the blame for the crime [Si cui casus hic imputandus est, mater sola crimen habet], because it is I who did not delegate anyone to protect her from the errors of childhood. I should have sent someone to supervise the girl, but I was blind. Return my daughter to me, Martyr! Woe is me! Before God a crime of negligence has happened [Coram Deo negligentice crimen incurro], and I cannot escape the infamous note before men. Return my daughter to me, Saint! ${ }^{183}$

Again, the miracle portrays more than just the idea of women being associated with death and lamentation. The story about the girl from Northwood showcases maternal affection and also acts as a confession of guilt regarding parental duties. In this account, it is the grief of the girl's mother — not the father — that is brought to the forefront of the miracle by William of Canterbury. The mother hurries to her daughter's corpse when she hears about the accident and immediately begins to weep at the scene. Her public grief completely overshadows the emotional response of the weaver, who initially finds the child's body floating in the pool of water. In fact, once the mother enters the story and begins grieving, the father's actions are not noted by the author at all, highlighting the mother's role in the emotional scene even more. Furthermore, the woman from Northwood assumes, not just some, but all of the blame for her daughter's death and her guilt increases as the story progresses. William of Canterbury highlights the idea that it

${ }^{183}$ William of Canterbury, Materials for the History of Thomas Becket Vol. 1, 366: "Redde mihi, martyr Thoma, filiam meam. Si cui casus hic imputandus est, mater sola crimen habet, quæ vagabundæ pueritiæ custodian non delegavit. Debui (sed cæca fui,) puero dedisse pædagogum. Redde mihi, martyr, filiam meam. Væ mihi! Coram Deo negligentiæ crimen incurro, et coram hominibus infamiæ notam non effugio. Redde mihi, sancte, filiam meam." 
was the mother's responsibility — not the father's— to watch over or delegate a custodian to supervise her child. While tears could be viewed as a sign of piety or love, they could also be seen as an indicator of $\sin .{ }^{184}$ In this case, they indicate the idea that the mother is at fault for her daughter's death. Because the woman neglects to supervise her daughter, she openly weeps and chastises herself within the story's dialogue, saying that she is the cause of the accident and that the child's death is a crime of neglect in the eyes of both God and the community. What is more, she is the one to offer the poignant plea to Thomas Becket for help, not the father. She assumes responsibility for her child's death and is the one to negotiate for the girl's recovery. The detail that the father is the one who tells the girl to wash off in the water pit is not brought up at all after it is first mentioned and appears to serve merely as context for the larger story at hand.

Authors of other miracle collections employed the emotion of grief in order to indicate maternal guilt. The anonymous author of the biography of Saint Edmund Rich of Abingdon, includes a poignant instance of overlaying in his work. He explains that a woman named Ersandis, after nursing, fell asleep and rolled onto her one-year-old infant. She woke up to her mother, Isabella, yelling, "Get up, get up, daughter, your daughter is crushed!" 185 Overwhelmed with grief, Ersandis spiraled into a frantic episode.

Swallowing intense tears (vehementia lacrimas absorbente), she ran back and forth shrieking and yelling that she was miserable and unfortunate (seque miseram atque

\footnotetext{
${ }^{184}$ Patton, Holy Tears, 206. Diane Apostolos-Cappadona states that Mechtild von Magdeburg viewed tears as being shed as repentance for sin.

${ }^{185}$ Murray, Suicide in the Middle Ages, 259: "Surge, surge, filia, ecce filiam tuam oppressisti." See also Lawrence trans., St. Edmund of Abingdon: A Study in Hagiography and History.
} 
infelicem vociferans) ${ }^{186}$ By describing Ersandis in this way, the miracle writer implies that she is undergoing an episode of madness. ${ }^{187}$ Extreme grief resulting in madness is also present in a miracle attributed to Wulfstan. Following the tragic death of her daughter, a mother from Worcester's sadness turned into insanity (dolore in insaniam versus est) and she was no longer able to recognize anyone, including her own husband. ${ }^{188}$ Grief leading to madness is not exclusive to English miracle stories. Finucane cites examples of miracles involving insanity on the Continent. In a French story, a threeday-old boy died, causing his mother to retreat into the woods and live amongst the wild animals. In a miracle from Italy, Joanna, a mother of three, ripped off her clothing and clawed at her face when she saw her son's body floating in water after a mill-wheel accident. ${ }^{189}$

${ }^{186}$ Murray, Suicide in the Middle Ages, 260.

${ }^{187}$ Insanity was not thought of as a permanent state, but rather an episode in someone's life that could cause them to act uncharacteristically during times of trauma. As a result, the desire to kill oneself or another person in a time of madness (prolonged or momentary) was not believed to be a true indicator of an individual's mental state, leaving the person unaccountable for their actions. Hunnisett, in the Medieval Coroner, asserts that "pardons were invariably granted to men who had committed to homicide in self-defense, accidently or while insane," 77. Evidence of coroners attempting to alleviate the circumstances of a crime on the grounds of madness can be seen in an inquest by William de Whattele and Richard de Eynesham recorded in Salter, ed., Records of Medieval Oxford, 26. The coroners reported that in 1343, on the Monday after the feast of St. Gregory, Henry de Bordesle of Oxford stabbed himself in the stomach during a moment of madness. Henry had been suffering from many ailments at the time, which caused a bought of insanity. In an example from Butler's "Women, Suicide, and the Jury," demonic possession and madness were related. Butler provides the story about a woman in the fifteenth-century Walsingham Chronicle, who repeatedly attempted to kill herself after going mad because of demonic possession. The woman was able to seek the help of a priest before perishing, 141-142.

${ }^{188}$ Darlington, ed., Vita Wulfstani, 146.

${ }^{189}$ Finucane, The Rescue of the Innocents, 154-155. 
In the overlaying case, Ersandis undergoes a similar abrupt and violent transformation because of her grief. Her grief becomes all-consuming as the narrative continues, so much so that it leaves her feeling helpless and open to the devil's attack. The author writes,

At the instigation of the enemy of mankind, and because of her sorrow and sadness, she slipped into the pit of despair [foveam desperationis]. Adding sins to sins, she wished to drown herself in order to end her shame [opprobrio finem inponere], making her last act worse than the very first... But her mother held her back and said, 'O how miserable I am, my daughter. What are you going to do? If you do this, you know that I will die with you, and you will be guilty of matricide. ${ }^{190}$

Imagery of homicide and suicide are juxtaposed within the passage to emphasize the cause of Ersandis's all-consuming grief: guilt about the role she plays in her daughter's death. According to the author, Ersandis not only commits one horrible deed by killing her daughter, but she also contemplates suicide. Because Ersandis is overwhelmed with grief caused by guilt, she is unable to properly ask for divine intervention, like the mother from Northwood. Instead her grief leads her to sin with thoughts of self-harm. If Ersandis had followed through with the felonious act of suicide, which she does not, she would have been ostracized in both her spiritual and earthly communities. ${ }^{191}$ Expressions of

${ }^{190}$ Murray, Suicide in the Middle Ages, 260: "Set instigante humani generis inimico lapsa est in foveam desperationis pre dolore atque tristicia que enim peccata peccatis adiciendo voluit se submergere, atque sic suo opprobrio finem inponere, atque novissima sua facere peiora prioribus...Set mater sua illam detinuit, dixit atque ei: 'O me miseram, filia mea, quid est quod vis agere? Scias si hoc egeris ego tecum moriar, atque sic eris matricidali polluti contagio."

191 The phrase "felo de se" translates to a "felony (or homicide) of the self." Even though suicide was usually a private matter, it had huge public consequences. Because suicide 
grief stemming from guilt do not end with Ersandis in this miracle. Ersandis' mother sees that her daughter is about to drown herself and is not willing to lose her child. She announces that she will be overcome with grief if Ersandis dies and that she will commit suicide as well, making the responses to child death cyclical. Both mothers recognize that they cannot live with the knowledge that they could not protect their children from harm and are willing to kill themselves to end their sadness and shame. While the grief that Ersandis and her mother experienced was also undoubtedly caused by maternal love, the author shows that grief was further heightened by motherly guilt.

In another miracle from the Thomas of Cantilupe collection, Richard of Wellinton's three-month-old daughter, Margery, is left alone in her cradle by her mother.

was treated as a form of homicide, families of those who were found guilty of the act by members of an inquest jury were required to forfeit all of their property and chattels to the king for a year and a day. Thus, kings often viewed a suicide or homicide verdict as a profit for the royal court, whereas communities saw these families as new burdens that they now had to support. In addition to the financial strain that suicide victims' families would incur, there was also the threat of the suicide victim being excluded from the spiritual community upon death. In other words, because they were social deviants in life, they were also treated as social "others" in death and were buried on the outskirts of a city or town, usually at a crossroads. According to Butler in "Cultures of Suicide?: Suicide Verdicts and the "Community" in Thirteenth- and Fourteenth-Century England," The Historian 69, no. 3 (2007), the living did not stop at burying a suicide victim a good distance from a city or village, but also took the time to decapitate or drive a stake through the corpse of the deceased, 435 . This harsh treatment towards the corpse of a suicide victim was performed for two main reasons. One of the reasons was to show the disrespect that the living had for the deceased. Another reason the corpse was mutilated stemmed from a fear that the "bad" dead could return to the physical world and wreak havoc on the world of the living and the only way to stop this process was through the destruction of the corpse. The earliest surviving example of this type of burial dates to the year 1510, with the death of Robert Browner from Suffolk. Robert hanged himself because of financial difficulties. For more information about this burial see William Halliday, "Wayside Graves and Crossroads Burials," Proceedings of the Cambridge Antiquarian Society 84 (1996), 113-118. 
The author of this story gives vivid detail about the reason for maternal grief. About the cause of the accident, he reports:

Likewise, there was an infant named Margery, the daughter of Richard Pink of Wellington, of the diocese of Hereford. She was released in her cradle without being under the care or custody of anyone [dimissa in cunabulo minus caute sub custodia cujusdam infantis alterius]. Because her mother was absent for some time [absente aliquamdiu matre sua], the cradle bonds were loosened as a result of too much movement of the child, and the child fell from the cradle. ${ }^{192}$

The author goes on to summarize the horror of this scene and the emotional toll it takes on the girl's mother. When Margery's mother entered the house, she saw her child hanging, suspended by her feet with the swaddling bands. She cried out (clamans) and began howling (ululans), which caused many neighbors to congregate around the miserable death scene (miserandum spectaculum) ${ }^{193}$ Similar to the stories of Ersandis and the mother from Northwood, Margery's mother experiences anguish not only because her child perishes from a senseless accident, but because of her role in the incident itself. The anonymous author points out that Margery's mother is to blame for her death in several parts of the story. First, he starts the miracle by reporting that Margery is left alone without any supervision. Second, he points out that Margery is left

\footnotetext{
192 Bolland, Acta Sanctorum, October 1, Section 645, 645: "Item infans quædam, nomine Margarita, filia Ricardi Pink de Welinton, Herefordiensis diœcesis, dimissa in cunabulo minus caute sub custodia cujusdam infantis alterius, absente aliquamdiu matre sua, vinculisque cunabuli resolutis, seu ex motu infantis nimis laxatis, a cunabulis decidit." In this passage, the term "laxatis," which comes from the verb "laxo," meaning "to loosen," refers to Margery loosening her swaddling bands, which are also tied to the crib in order to prevent her from moving around too much.

${ }^{193}$ Bolland, Acta Sanctorum, October 1, Section 645, 645.
} 
alone so long that it leaves her with enough time to free herself from the swaddling bands without anyone noticing or re-tightening them. Another criticism of Margery's mother is subtler in nature. In the last sentence of the excerpt, it is explained that Margery is able to loosen her swaddling bands. While the author could simply be reinforcing the idea that Margery is left unattended for far too long, he might also be suggesting that her swaddling bands were not secured tightly enough by her mother because they were easily loosened, further contributing to her accidental death. A similar criticism is found in a Henry VI miracle, which will soon be discussed in more detail. The final indicator that the author assigns blame to her mother in this scenario can be seen in the way in which she is depicted mourning. Although the vocal nature of the grief displayed in this miracle could be viewed as someone initiating the crime-investigation process (i.e., raising the hue and cry), it is evident that the cries of Margery's mother stem from utter sadness and transcend the private realm because her guilt over the situation is so strong. To show this extreme sadness, the narrator describes the mother as morphing into an inhuman creature throughout the grieving process. She starts off crying out loudly (clamans), and eventually, her cries become so strong, that they turn into the howls (ululans) of an animal that can be heard beyond the walls of her home.

Priests gave parents tips on how to swaddle their children correctly because deaths such as Margery's were common. The custom of swaddling children was widespread in medieval Europe. Female saints, such as Catherine of Bologna, claimed to have visions of Christ wearing traditional swaddling garb (ita fasciis involutum ut infantes recenter nati solent), and depictions of swaddling clothes can even be seen in 
illuminated manuscripts depicting Christ's birth. ${ }^{194}$ One illustration of Christ in swaddling clothes can be found within the "Neville of Hornby Hours (henceforth the "Hornby Hours")," a traditional book of hours containing prayers, poems, and psalms. According to Kathryn Smith, the patron of the "Hornby Hours" was most likely Isabel, the daughter of Sir Robert de Byron of Melling Manor in Lancashire, and wife of Sir Robert I de Neville of Hornby Manor, who is portrayed in multiple donor images throughout the manuscript. The book was commissioned for private devotional use, during a time when there was an "explosion of devotional forms," and a rise in lay literacy. ${ }^{195}$ The blueframed Nativity scene on folio 13 of the "Hornby Hours" sits on top of Gothic script, with foliage around the edges. In the center of the scene, the Virgin Mary rests on a bed of lavish orange and gold bedsheets after the birth of Christ, while Joseph and a midwife sit by her side. Above them, the magi and two animals look down in wonderment at the Christ child. Directly behind the midwife lies Christ, elevated on a massive cradle-like bed. The white fabric wrapped around Christ is taut and secured by swaddling-bands, which are fastened from around his neck, down to his ankles.

Although the image above portrays a popular swaddling technique of the Middle Ages, swaddling methods changed over time, and varied from season-to-season and region-to-region. In the early medieval period, Anglo-Saxon babies were wrapped tightly in clothing, but there is no evidence of bands being used to keep the clothing in place. By the thirteenth century, most infants were fastened into a bundle, either with their limbs

\footnotetext{
${ }^{194}$ Bolland, Acta Sanctorum, March 2, Section 47, 57; "thus bundled, such as those costume to infants recently born."

${ }^{195}$ Kathryn Smith, "The Neville of Hornby Hours and the Design of Literate Devotion," The Art Bulletin 81, no. 1 (1999), 72.
} 
free from the swaddle completely, or with their arms and legs bundled into the swaddling clothes. To fasten a child into this bundle, long pieces of cloth called "cradle bands" or "swaddle-bands," would be wrapped around the infant in a crisscross pattern. Swaddling bands were utilized to ensure that children could not easily move around in their swaddling clothing. ${ }^{196}$

The age to which children needed to be swaddled in uncertain, but, medieval people believed that there were a variety of reasons why children needed to be swaddled by their caregivers. ${ }^{197}$ Today, swaddling is promoted as a means of soothing infants. Some pediatricians argue that swaddling recreates the experience of living in the womb, whereas others say that the tightness of the swaddle causes a calming reflex and even prevents sudden infant death syndrome (SIDS). ${ }^{198}$ In the medieval period, parents were encouraged to swaddle children, lest they grow up with disproportionate body parts. It was a common belief that because children were soft and flexible, they needed to be

${ }^{196}$ A six-month-old infant in the biography of Hugh of Lincoln is described as not being fully wrapped in his swaddling clothing, with his torso and arms left to dangle on the outside of his bands. See Decima Douis and David Farmer, ed. and trans., Magna Vita Sancti Hugonis: The Life of St. Hugh of Lincoln, Vol. 1 (Oxford: Oxford University Press, 1961), 128-130, for more about this account. In Childhood in the Middle Ages, Shahar explains that medical writers reinforce the idea that full-body swaddling was not always practiced. Physicians encouraged wet-nurses to stimulate an infant's limbs with a series of exercises, such as pulling or moving an infant's hands, 86 .

${ }^{197}$ In "Medievalists and the Study of Childhood," Speculum 77, no. 2 (2002), 550, Hanawalt argues that children were encouraged to be swaddled until the age of two. In a miracle account, the maximum swaddling age is suggested to be around one year. Ambrose of Siena is recorded as breaking out of his own swaddling clothes by this age. See Bolland, ed., Acta Sanctorum, March 3, Section 3, 182.

${ }^{198}$ Debates about whether or not swaddling is effective in preventing SIDS is ongoing, and Ralph Frenken, in "Psychology and History of Swaddling, Part One: Antiquity until $15^{\text {th }}$ Century," Journal of Psychohistory 39, no. 2 (2011)," argues that new medical studies have shown that swaddling can contribute to SIDS, 91. 
swaddled so that their limbs would be held in the correct position. This idea was not purely medieval. Ralph Frenken explains that swaddling was practiced as far back as the Paleolithic era, but it was the Greeks who commented extensively on the reason for swaddling children. The Greek physician, Soranus of Ephesus (98 AD), believed that swaddling was a medical necessity that prevented the dislocation or distortion of the limbs. ${ }^{199}$ Orme explains that while proper limb formation was the dominant reason to swaddle children, parents may have also used swaddling as a way to keep babies warm and hold them on their laps more easily as they performed other household activities. ${ }^{200}$ Another benefit of swaddling was protecting children from harm. Swaddling clothing and bands protected infants from animals and from falling into hazards around the household. Although one reason to swaddle children was to keep children healthy, this was not always the case. Swaddling clothes were not always changed regularly. Because of this, swaddling clothing masked diseases and deformities, or caused sores and rashes on children's skin. ${ }^{201}$ Furthermore, swaddling was not a guaranteed protection from danger. When not swaddled properly, infants could free themselves from their bands and easily fall out of laps or cradles, as we saw in the Thomas of Cantilupe miracle..$^{202}$

${ }^{199}$ Frenken, "Psychology and History of Swaddling," 85.

${ }^{200}$ Orme, Medieval Children, 62.

${ }^{201}$ Shahar, Children in the Middle Ages, 85.

${ }^{202}$ In addition to swaddling, babies were regularly fastened into their cradles. Cradles varied in style and size. Some had buckles along the sides so that parents could tie swaddling bands to them for extra protection. The household ordinances of Henry VII show the royal cradles as being constructed of painted wood, four pommels of silver and gilt at the corners, and five silver buckles. When bands were not secured to buckles properly, babies could fall out of cradles easily. To make matters worse, many cradles were suspended off the ground, some even hung from the roofs of houses, to make them easier to rock back and forth. Thus, a fall from a cradle could be deadly. This is what 
Authors also portrayed mothers as assuming culpability for child death caused by illness. In a Thomas Becket miracle, the Countess of Clare, Matilda, losses her son to a ruptured hernia. Thomas Becket had cured the son of his illness long before, but it came back, this time with fatal consequences. When he died, Matilda expressed her grief to the holy man,

Saint Thomas, long ago you returned my son to me. Why did you give him back, only to cause maternal grief [maternum luctum]? You cured the illness that caused miserable pain. Woe is me! How have I sinned? What command have I gone against to endure bereavement? [quo nunc peccato, qua transgressione mandatorum, damnor orbitate]. ${ }^{203}$

In this miracle, Matilda, in her state of mourning, questions why Thomas Becket punishes her with the death of her child. Even though she is not in control of the boy's illness, she blames herself, and any possible sins that she has committed on the boy's death. This guilt, along with the love for her child, cause her to become a grieving mother.

One miracle attributed to King Henry VI, which dates to 1490 , deviates from the other miracles about grief and guilt in that the narrator overtly states his opinions about motherly responsibilities, even more so than the author of the cradle death in the Thomas of Cantilupe miracle story. Rather than simply portraying a mother as lamenting and

appears to have happened in the miracle associated with Margery. Floor-based cradles, such as baskets and boxes were used by less wealthy households and also proved dangerous because children were more accessible to roaming animals. See Orme, Medieval Children, 62 and Thomas Hearne, ed., De Rebus Britannicis Collectanea, John Leland Vol. 4 (London: Impensis Gul \& Jo. Richardson, 1770), 183-184.

${ }^{203}$ Benedict of Peterborough, Materials for the History of Thomas Becket Vol. 2, 229:

"Sancte Thoma, pridem puerum mihi reddidist; cur ad maternum luctum reddere voluisti? Morbum, quo misere cruciabatur, curasti; væ mihi, quo nunc peccato, qua transgressione mandatorum, damnor orbitate?" 
expressing her guilt through speech and gestures when her child dies, the author condemns a mother from Brackley, Northamptonshire. This miracle story can be divided into two main parts. In the first half, the narrator prefaces the account of child death with two pieces of advice for parents, the first addressed specifically to mothers. He asserts that infants ought to be in the care of their mothers (debet esse cura matrum in proprios fetus), lest anything bad happen while they are unsupervised. Then he warns both parents that "For where something negligent is done to infants, much adverse fortune follows; permitting an infant to have its pleasure so often turns laughter into tears, joy into mourning, clapping into beating [the chest], joking into weeping." ${ }^{204} \mathrm{By}$ beginning the text with these two warnings, we learn the narrator's stance on who is to blame if a child sustains injuries or dies: the parents, especially mothers who do not vigilantly attend to their young children.

In the second part, the actual miracle story, the author explains that a six-monthold named George dies because he was not swaddled correctly by his mother, Olivia. Instead of wrapping him as is customary (ut solito), Olivia rolls George up in cloth, ties it loosely with a linen belt, and puts him into his cradle for the night. Upon waking to nurse George, Olivia reaches for his little body (corpusculum) and finds him hanging by the belt from his cradle, which was suspended above the floor. As she unties the belt around his neck, George falls to the ground like a mass of clay (veluti massa luti) and Olivia quickly spirals into despair. She is described as experiencing anguish (dolore), sighing

\footnotetext{
${ }^{204}$ Grosjean, ed., Henrici VI, 260: "Nam ubi negligencius aliquid geritur in infantes, adversa plerumque fortuna insequitur, que dum libitum suum habere permittitur, quamsepe in lacrimas risus, in luctus gaudia vertit, in planctum plausus, in lacrimosa iocos."
} 
and continually lamenting (gemitibus incessabilibus lamentando), erupting into sobs (erumpentes singultus), and crying so much that her face is drenched in tears (lacrimis ora perfudit). The narrator interjects to remind his readers that Olivia is at fault for the infant's death. He writes that grief-stricken, and tempted by the devil (corruptore), she thought about throwing the child to the side and fleeing the scene, but neighbors heard her cries and came to console her in the moment of distress. Olivia eventually pleads to Henry VI for the revival or her son. ${ }^{205}$

The author of Olivia's story turns the tragedy of child death into a didactic admonishment. He does not simply hint at the mother's role in the death of her child, but rather tells his readers that she is to blame by adding his own voice to the story, beginning with his advice to parents in the introduction. When he starts to narrate the events that occur in Brackley, he immediately mentions that George is not wrapped in the traditional swaddling method, pointing the finger at Olivia once again. He even stresses that Olivia experiences guilt because she is tempted by devil to hide the body and run away from the death scene. One couple in a miracle story did actually follow through with hiding a deceased child's body. When a child was crushed by his father's ox-cart in a Thomas of Cantilupe miracle, his parents hide his body in their bed because they are terrified of being investigated for neglect by the king's officers. ${ }^{206}$ Olivia, although she does not get rid of the body, does not initially follow proper legal or religious protocol

\footnotetext{
${ }^{205}$ Grosjean, ed., Henrici VI, 261-262.

${ }^{206}$ Valerie Flint, "The Saint and the Operation of the Law: Reflections upon the Miracles of St. Thomas Cantilupe," in Belief and Culture in the Middle Ages: Studies Presented to Henry Mayr-Harting, eds. Richard Gameson and Henrietta Leyser (Oxford: Oxford University Press, 2001), 342-357.
} 
when her son dies. She does not alert neighbors by raising the hue and crying or cry out for any help to revive her son. Olivia, like Ersandis, is consumed by grief, which ultimately leads her to sin under the devil's influence. In the case of Olivia, however, the author alludes to the idea that Olivia knows that she will be charged with neglect, whereas Ersandis wants to commit the sin of suicide because she is ashamed of her actions. This portrayal turns this part of the story about Olivia into a confession of her guilt and highlights her bad maternal instincts even further. In fact, it is not until her neighbors arrive at her house that she decides, or feels obligated, to stay. By including these details in the story, the author amplifies his presentation of Olivia's culpability and demonstrates the legal consequences of not performing, in his eyes, her most basic parental duties.

Whether miracle stories depict actual events or not, they would have served as didactic literature for mothers. Hearing reports about child death and maternal grief would have not only encouraged women to venerate Edmund Rich of Canterbury, Wulfstan, Thomas Becket, Thomas of Cantilupe, and Henry VI, but also would have instructed them about or confirmed expectations for motherly love and parental care.

\section{MATERNAL GRIEF IN MEDIEVAL LYRICS}

Medieval lyrics, particularly those found within Middle English lullabies, are another source that illustrate the relationship between women and their children and the guilt that they endured when they could not protect them from harm. While the word "lullaby" originates from the Latin lallare, meaning "to sing a soothing song," medieval 
lullabies ironically did not always conjure comforting scenes. ${ }^{207}$ Hanawalt explains, "Traditionally, we think lullabies are supposed to reassure the baby, singing of good things that will happen and protective people and surroundings; but not so the medieval versions." ${ }^{208}$ Mothers would sing about "Deth" coming for their children, or of the Virgin Mary singing to Jesus about his tragic fate. ${ }^{209}$ Mary was a key figure in medieval Christianity because of her role as mediator between God and mankind. By the early Middle Ages, the Church had devoted Saturdays and several feast days to the Holy Mother and in 1215, the Lateran Council agreed that the laity should be required to learn the Ave Maria. Because of her popularity, she was a familiar subject in medieval lyrics, the oldest of which are rhymed translations of the Ave Maria found in learning materials alongside the Pater Noster and Creed. ${ }^{210}$

Nativity lullabies do not specifically contain imagery of medieval women and their children; however, the authors of these lyrics undoubtedly expected women to follow the model of the Holy Mother. While reading, hearing, or singing Marian lyrics, medieval women would have drawn parallels between their own experiences and those of Mary; Mary was not only the Queen of Heaven, but also a religious figure with whom women could identify as mother. Because Mary was the mother through which God was

\footnotetext{
207 Vines, “Lullaby as Lament,” 201-224.

${ }^{208}$ Hanawalt, The Ties that Bound, 179.

${ }^{209}$ Davies, ed., Medieval English Lyrics, 107.

${ }^{210}$ Karen Saupe, ed., Middle English Marian Lyrics. Dissertation, University of Rochester, 1996, 7-8.
} 
born man, women could turn to Marian lyrics for guidance in parenting and solace in the face of child death. ${ }^{211}$

Lullabies about the Nativity convey the deep love between Mary and her child and the grief that Mary experiences upon learning the prophecy of his death. One anonymous Nativity lullaby composed sometime between the fourteenth and fifteenth century, describes a private conversation between Mary and the Christ child. The tone of the lullaby gradually shifts from joy, as Mary recalls the celebration surrounding Christ's birth, to sadness, as she hears the details of his future death. The child warns his mother of her future mourning caused by his grim fate in lines 117-118, "Mother, you shall mourn a lot / And see me die painfully." ${ }^{212}$ Christ acknowledges that his mother's love for him is strong, so strong that she will endure much anguish when he dies. The Gospel of Luke contains a similar prophecy of grief over Christ's death when Mary presents Christ at the temple. Simeon announces that her soul will be pierced with a sword when Christ dies for the salvation of men. ${ }^{213}$ The narrator of the lullaby evokes a sense of pathos with Mary's reaction in the next couple of lines: "Alas Son," said that maiden, / "Since that is so, / Why must I live to see that day, / To bear you for this woe?"214 Mary's distress is the central topic of her dialogue within the lyrics. She questions why she must live to see her son perish and why she gave birth to Christ, only to have him suffer. In

${ }^{211}$ Saupe, ed., Middle English Marian Lyrics, 10.

${ }^{212}$ Saupe, ed., Middle English Marian Lyrics, 87: "Moder, thu salt maken michil mon / And seen me deyye sore."

213 “Gospel According to Luke 2. 35.” Douay-Rheims, drbo.org.

${ }^{214}$ Saupe, ed., Middle English Marian Lyrics, 87: "Allas Sone," seyde that may, / "Sithen that it is so, / Worto sal I biden that day, / To beren thee to this wo?" 
another lullaby, this time from the fifteenth century, there is a rare instance of Jesus comforting his mother as she mourns his future death. Mary yells, when learning of her child's fate, "Peace! dear son, do not say that to me. / You are my child, I have no more. / Alas, I should see this misfortune / It is a sad plight to me. / Alas! Dear son, my happiness is no more." 215 To all of this, Jesus encourages Mary to have hope because he is dying for the sake of mankind. Vines asserts that Marian lyrics such as these "transform the emotional intimacy of the first interaction between mother and child into a lesson in parental mourning." ${ }^{216}$ Since the Nativity scene is the most 'human' of Mary's five joys, it allows the reader to learn from Mary's mourning process and reflect on and understand the meaning of Christ's sacrifice more fully. ${ }^{217}$ As Vines states, Nativity lyrics allowed medieval women to learn from Mary's emotions, but more than that, the lyrics speak to the love between a mother and her only child, that of Mary and Christ.

Additionally, they display the sense of guilt that Mary feels when she learns that she will not be able to save him from a premature death, a reaction that lines up with the mothers in the miracle stories.

Lyrics about the actual Crucifixion paint a similar picture of Mary and Christ. In Passion lyrics, Mary is often depicted, alongside the disciple John, as standing and sometimes wepyng, or "weeping" for her child at the foot of the Cross, while either Christ

\footnotetext{
${ }^{215}$ Davies, ed., Medieval English Lyrics, 197: "Pes! dere sone, say thou me not so. / Thou art my child, I have no mo. / Alas! That I should see this wo; / It were to me gret heivynis. / Alas! dere son, sorry now is my happe."

216 Vines, "Lullaby as Lament," 202.

${ }^{217}$ Vines, “Lullaby as Lament,” 203, 206-207.
} 
or the narrator elaborate on why he must be sacrificed for the sins of mankind. ${ }^{218}$ Some Passion lyrics contain more detail about the grief that Mary experiences over the loss of her child on the Cross. A mid-fourteenth-century lyricist brings Mary's sorrow to the foreground in an eight-line lament over her dying child. Mary exclaims, "Why have you no pity on my child? / Have you pity on me, full of mourning. / Take my worthy child down from the Cross, / Or impale me on the Cross with my darling. / More pain may never be done to me / Than to let me live in sorrow and shame. / All my love is bound to my son, / So let us die both the same." ${ }^{219}$ Like the composers of Nativity lullabies, the writers of Passion lyrics depict the bond between mother and child and the guilt that Mary experiences over her inability to protect her son, but this time while his death is actually taking place. Parallels can also be drawn between these Passion lyrics and the miracle stories mentioned in this essay. Mary, like the mothers in miracula, negotiates for the safety of her son, not with a saint, but with her child's executioners. Furthermore, she grieves in front of people, not a community, but the crowd that is watching her son's suffering. Instead of grieving quietly by the Cross, Mary plays an active role in the Passion scene. She assumes the role of Christ's protector, calls out to his persecutors, and begs them to take pity on her, a grieving mother, and her dying child. If they will not take him down from the rood, she wants them to impale her on the cross with him. Mary's love for her child binds her to him and makes her an extension of him. If Christ is in pain,

\footnotetext{
${ }^{218}$ Robert Stevick, ed., One Hundred Middle English Lyrics (Indianapolis: The BobbsMerrill Company, 1964), 22-23, 29.
}

${ }^{219}$ Davies, ed., Medieval English Lyrics, 119: "Why have ye no reuthe on my child? / Have you reuthe on me, full of murning. / Taket down on Rode my derworthy child, / Or prek me on Rode with my derling. / More pine ne may me ben don / Than laten me liven in sorwe and shame. / Als love me bindet to my sone, / So lat us deiyen bothen isame." 
Mary feels as though she should endure the same type of pain. In other words, Mary's grief highlights not only the love that she has for her son, but also the idea that she must suffer with her child if she cannot save him, since she, as his mother, is responsible for his fate.

\section{CONCLUSION}

While it is true that child mortality was high in medieval England, especially considering the dangers of childbirth, perils of health complications, and the prevalence of accidental deaths, the argument that children were social "others" until a certain age does not hold true when looking at the sources, especially reports of grieving mothers. Religious authors highlighted maternal grief associated with child death in miracle stories and lyrics dating between the twelfth and fifteenth centuries. Although these documents differ in time and purpose, the authors of these records consistently employed the emotion of grief in order to underscore expectations for mother-child relationships, as well as gendered expectations for childrearing. In miracle stories, religious men described mothers as showing love for their children through public grief and persistent efforts to revive them from death. Public grief was also used in rhetoric to stress the guilt that women should endure when they could not protect their children from harm. Grief and guilt could be so overwhelming that women contemplated self-harm or going against legal protocol. Similarly, the paragon of motherhood, the Virgin Mary, is portrayed in medieval lyrics as having a strong bond with the infant, Christ, and mourning publicly when she realizes that she will not be able to protect him from his death on the Cross. In 
lyrics where he is dying on the Cross, she wishes to die with him, since she cannot protect him from death.

When reading or hearing about maternal grief and child death in lyrics or miracle stories, women would have absorbed the idea that they were largely responsible for the state of the domestic sphere, especially for the safety of children. Therefore, when we read about the mother of Margery howling from grief or the mother in Northwood crying about her role in her daughter's drowning, we must understand that authors of medieval sources put forth the idea that maternal grief stemmed not only from women loving their children, but also from the sense of guilt that they were expected to have when they failed in their obligation to protect them from themselves and the outside world. The following chapter will examine accounts of paternal grief in order to demonstrate the similarities and differences between female and male grief associated with child death. ${ }^{220}$

${ }^{220}$ The research and writing from most of this chapter can also be seen in my fortcoming publication called "A Mother's Guilt: Female Responses to Child Death in High and Late medieval England," in Literary Cultures and Medieval/Early Modern Childhoods (Palgrave Publishing, forthcoming), eds. Naomi Miller and Diane Purkiss. 


\section{Chapter Three}

\section{"I Beg You Father, Do Not Mourn For Me": Displays of Paternal Grief}

Benedict of Peterborough reports that the hand of the Lord weighed down heavily on a knight named Jordan, the son of Eisulf (Aggravata est manus Domini super militem nominis magni Jordanum Eisulfi fillium) and struck his household with plague from August until Easter (percussit domum ejus plaga a tempore Augusti usque ad dies Paschales). First, the nurse of his ten-year-old son, William, perished and was buried, and then days later, the boy also succumbed to the disease. Benedict of Peterborough writes about reaction to the boy's death: “Of the parents' unlimited sorrow, I stay silent, but anyone, however simple, will be able to imagine it." ${ }^{221}$ He goes on to say that, on the same day, around twenty pilgrims returning from Thomas Becket's memorial, arrived at the scene (Supervenerunt eodem die peregrini a martyris memoria revertentes, numero circiter viginti). Despite the grim circumstances, Jordan offered the guests hospitality because of his love for Thomas Becket (quos omnes paterfamilias pro martris amore suscepit hospitio). The next day, however, Jordan's demeanor changed. A priest arrived to take William's body to the church for burial, but Jordan refused to let this happen, telling the priest that there was no way (Nequaquam) that his son's body would be carried away, because his heart told him (vaticinator mihi cor meum) that the boy would be revived by Becket water brought by the pilgrims. The priest, although thinking this was

${ }^{221}$ Benedict of Peterborough, Materials for the History of Thomas Becket Vol. 2, 229: "De luctu parentum immoderato sileo, quem quilibet etiam simplex imaginari valebit." 
strange, poured Becket water into the boy's mouth, but the child remained dead. ${ }^{222}$ The priest asked Jordan again to bury the child, but Jordan reiterated that his son would not be buried (Nequaquam sepelietur filius meus). More water was poured into the child's mouth, and eventually he showed signs of life, a full day after his death. When William finally opened his eyes, he asked his parents, "Why do you cry father? Why do you cry mother? Don't be sad. Behold! Martyr Thomas has given me back to you!"’223 In appreciation for his son's resuscitation, Jordan promised to dedicate him to Thomas Becket during the Lenten season. ${ }^{224}$

The story about Jordan and his son is filled with emotional language and imagery. Benedict of Peterborough points out both maternal and paternal grief within the account. Yet, it is William's father, Jordan, that is at the forefront of the revival story. Although Jordan is described as shedding tears over his son's death, he is able to restrain his grief when visitors arrive at his home. He seemingly has no trouble being a good host to his guests, especially since they are returning from Thomas Becket's shrine. At first glance, Jordan's response to his son's death appears almost callous. However, when he refuses to bury his son, it becomes evident that he was inwardly grieving and not just dismissing his son's death altogether. This reaction to death is a stark contrast to what we saw with the

${ }^{222}$ Benedict of Peterborough, Materials for the History of Thomas Becket Vol. 2, 229230 .

${ }^{223}$ Benedict of Peterborough, Materials for the History of Thomas Becket Vol. 2, 230: "Cur polars, pater? Quare fles, domina? Nolite tristari; en, reddidit me vobis beatus martyr Thomas."

${ }^{224}$ Benedict of Peterborough, Materials for the History of Thomas Becket Vol. 2, 230. There is another part to this miracle concerning the parents fulfilling their vows to Thomas Becket, but it will be discussed later in the chapter. 
mothers in Chapter Two. The women, while in the midst of grieving, did not go on with daily routines, or attempt to restrain their grief in front of others. In fact, most of the time, their outward grief alerted others to the fact that something horrible had happened.

The focus of this chapter is on paternal displays of grief. I demonstrate that fathers were portrayed as grieving over their children in two main ways. First, paternal grief, like maternal grief, could be outwardly expressed. Fathers cried out in distress (clāmor), experienced sadness (dolor), howled with despair (ululatus), and even endured extreme states of mourning. I argue that outward paternal grief was more restrained in comparison to mothers in that it did not usually attract the attention of other community members. There was also a limit as to how public and lasting paternal grief could be. Men were criticized when they grieved too heavily. For example, authors referred to immoderate paternal mourning as being "womanly" or portrayed fathers as losing sight of their faith and the role of paterfamilias. Therefore, authors used grief in their writings to put forth expectations about religious devotion, household duties, and gender-appropriate forms of grieving. Furthermore, blame for a death was never attached to paternal grief, as we saw that it was in the previous chapter. That is to say, fathers are not indirectly or directly blamed for the death of their children, even if children perished under their care. Second, authors of miracle stories also gave fathers different ways of expressing grief in comparison to mothers. In addition to publicly lamenting, fathers were depicted as practicing complete emotional restraint, such as showing grief through prayer or other forms of religious devotion. Portraying grief in this way, allowed authors to stress proper religious protocol in the face of child death. 
The idea that excessive grief could cloud one's mind and turn them away from religion is also highlighted within the poetic lines of the Middle English Pearl and the dialogue of the Brome Abraham and Isaac mystery play. In these texts, fathers experience heartbreak over the loss (or the thought of the loss) of their children, just as the fathers do in the miracle stories. The father in the Pearl feels desolated grief (deuely dele) when his daughter perishes, whereas Abraham's heart, knowing that he must sacrifice his son, breaks in two (hart brekyth on tweyn). Similar to the fathers in the miracle stories, grief is used to depict the love that the father in the Pearl and Abraham have for their offspring. However, it is also employed to criticize them when they let grief come between them and their faith.

\section{PATERNAL GRIEF IN MIRACLE STORIES}

Miracle stories contain several examples of public paternal grief over the loss of children. In one account, a man named John Berow and his stepson, John Searle, were out working in the fields when the child got gored by an ox in the neck and was horribly mutilated (horribiliter laceratum). According to the narrator, upon seeing this, his stepfather was stunned, he started to shake (tremuerit) and his heart was weakened (concusso corde). With life draining from the boy, his stepfather internally groaned (interno gemitu) and a fountain of tears erupted from his eyes (erumpentibus exuberanter fontibus lacrimarum). ${ }^{225}$ Trying to think of a remedy, he remembered to call upon Henry VI for help. He prayed with all his heart (Fecitque continuo toto corde) for the boy's

\footnotetext{
${ }^{225}$ Grosjean, ed., Henry VI, 275-276.
} 
recovery. Soon, the blood pouring out of the boy's wounds ceased and he was eventually restored to perfect health. ${ }^{226}$ In another miracle, this one from the Thomas Becket collection, the son of Eudes of Parndon was seemingly dead from an illness. When his parents saw no signs of life on the boy's body, both of his parents leapt forth with cries and shrieking (clamantes et eiulantes exsiliunt). His mother continued mourning with a group of neighbors (hinc mater convocatura vicinas), while his father privately wailed in the garden (hinc pater secretius ploraturus in horto). While in the garden, he kneeled and prayed to Thomas Becket (flexis genibus martyris) for his son's recovery. When he went back into his house, he found that his child had been restored to life. ${ }^{227}$ There is also the miracle about Hugh Scot from Cheshire that was used in the introduction to this dissertation. When Phillip drowned in a lake, his father, Hugh Scot, uttered sighs and groans (suspiriis et gemitu), while his wife indulged in tears and wailing (lacrymis indulget et plactui). The boy was eventually revived with Becket water. ${ }^{228}$ In another miracle, this one from the Simon de Montfort collection, John, the son of Philippy of Kent drowned. His father, groaning and shedding tears (gemens et lacrimans), extracted him from the water and carried his body home. Then, he measured the boy to Simon de Montfort and the child was immediately revived (mensuravit, et statim convaluit). ${ }^{229}$

The love that the fathers had for their children shines through in all of the stories. Each father is depicted as outwardly expressing grief when their child dies, which

${ }^{226}$ Grosjean, ed., Henry VI, 276.

${ }^{227}$ Benedict of Peterborough, Materials for the History of Thomas Becket Vol. 2, 188.

${ }^{228}$ William of Canterbury, Materials for the History of Thomas Becket Vol. 1, 201.

${ }^{229}$ Halliwell, ed., The Miracles of Simon de Montfort, 105-106. 
underscores the emotional attachment that they had for their children. Hugh Scot utters groans and sighs, Phillippy groans and sheds tears, Eudes wails in his garden, and John Berow not only groans and erupts into tears when he sees his stepson dying, but also starts to shake because of his grief. What is more, he is so sad, that his heart is described as "weakening," possibly a reference to being "broken-hearted." Although these fathers express outward grief like the mothers of Chapter Two, two main differences can be seen in the accounts. One major difference is that no blame is attached to the fathers for the deaths of their children, either by themselves or directly by the authors of the stories. There are no confessions of culpability and no warnings to parents about proper child care. Not even John Berow expresses guilt for not being able to protect his stepson as they work together with the oxen. This strengthens the argument that, even though both parents were held liable for child safety, mothers were viewed as being more responsible for protecting children around the domestic sphere.

Another difference is that, even though the authors of these miracles represent these fathers as outwardly grieving their losses, they do not portray them as attracting crowds with their cries, as we saw with mothers. John Berow remains alone in the field with his son as he cries, Hugh Scot sighs and groans, but only when he initially finds his son's body, Phillippy groans and cries alone as he carries his son's body to his house, and Eudes of Parndon hides his wailing in his private garden, while his wife laments the loss of their son with fellow community members. Even Jordan, in the introduction to this chapter, restrains his grief in front of guests. ${ }^{230}$ The authors of the miracles portray

${ }^{230}$ A miracle that resembles the one about Jordan in terms of emotional restraint and going on with daily affairs in the midst of child death is found in the Thomas of Cantilupe collection. The author of the miracle notes that, when a boy named William of 
paternal grief as being somewhat restrained in comparison to women. They did outwardly show grief, but whole neighborhoods and communities did not necessarily hear their cries or come running because of their distress. This is especially true in the miracle about Eudes of Parndon and his son. He purposely removes himself from his wife and neighbors in order to grieve alone in his garden and contemplate what to do next. This restraint of grief allowed these men to focus on correct religious protocol (i.e., summoning divine intervention), which eventually leads to their children being resuscitated in the end. In other words, it is not Eudes's wife who revives her son, but Eudes who grieves in private and is able to gain clarity on how to revive his child, thus becoming the moral example of the story.

The idea that restrained grieving led to correct religious protocol is not only highlighted in these miracles, but also in an alternate account of the Hugh Scot miracle, which was written by Benedict of Peterborough. Several parts of the miracle are different than the account given by William of Canterbury. For one, Benedict of Peterborough states that the miracle occurred in Warwickshire and not Cheshire. Second, he does not mention that Hugh Scot sighs and groans upon finding his drowned son. Rather, Benedict of Peterborough simply states that both parents were anxious (anxio parentum) at the death of their boy. ${ }^{231}$ Third, there is a declaration made to Thomas Becket that we don't

Donington drowned in a stream, his father kept his dinner plans instead of coming home to grieve over the child. See Finucane, The Rescue of the Innocents, 106-107. There is another Thomas Becket miracle about a man who grieves over the death of his child. William of Canterbury says that he is persistent in his tears (persistente eo in fletu) and asks Thomas Becket for help. This man, too, does not attract other community members. William of Canterbury, Materials for the history of Thomas Becket Vol. 1, 484.

${ }^{231}$ Benedict of Peterborough, Materials for the History of Thomas Becket Vol. 2, 238. 
see in the other story. Instead of only recounting details about the revival by Becket water, Benedict of Peterborough tells us that neighbors suggest that a priest come to the house to give the boy his last rites. Similar to Jordan, Hugh Scot loudly protested (reclamavit) the idea of burying his son and said, "So help me God, if Saint Thomas does not bring back my son to me, then he will have him in Canterbury dead. For I will either lead him there alive or carry him there dead. There is no way that my son will be buried here." ${ }^{232}$ After his plea, he poured Becket water into Phillip's mouth. Becket water served as a revival method in the martyr's miracle stories. It was said that when Thomas Becket was attacked in the cathedral by Henry II's knights, a large quantity of his blood was left behind on the paving stones. Monks collected the blood and diluted it with water not only to increase the amount of blood available for distribution, but also to disassociate Thomas Becket's blood from the blood of Christ. Jordan argues that there existed no hagiographic precedence for the consumption of a martyr's blood and the only holy figure in Christian doctrine who associated prominently with blood was Christ himself. By diluting the blood, Becket water could remain unique, but could still be paralleled to the metaphor of Christ's blood. ${ }^{233}$ The Becket water worked in the case of Phillip and he opened his eyes after taking in the liquid. His father asked, "Son, do you wish to live?" to which Phillip

\footnotetext{
${ }^{232}$ Benedict of Peterborough, Materials for the History of Thomas Becket Vol. 2, 239: "Adjuvet me ita Deus, nisi eum beatus Thomas hic mihi restituerit vivum, habebit illum Cantuariæ mortuum. Illuc enim eum vel vivum ducam vel mortuum portabo; nequaquam hic seplietur."

${ }^{233}$ Jordan, "The Water of Thomas Becket," 482. Jordan also explains that diluting Thomas Becket's blood may have been a way to make the healing liquid more appealing to drink for pilgrims seeking cures.
} 
replied, "My father, I do wish to live." ${ }^{234}$ In this account, Hugh Scot shows his grief, not through publically sighing and groaning, but through his refusal to bury his son and prayer. It is also significant to note that Hugh Scot's sadness is also apparent because of his anger at the saint for not quickly reviving the child. He basically goads Thomas Becket to revive his son, stating that if he does not cure him, he will take the boy to his shrine and keep asking for resuscitation. Similar discourse is seen in another miracle in this chapter and much more aggressive language is used. In the end, Hugh Scot's appeal to Thomas Becket and the implementation of Becket water revives the boy, making Hugh Scot inexplicably happy (inexplicabiliter loetus). ${ }^{235}$

Paternal emotional restraint can also be seen in miracles about fathers performing religious rituals in exchange for a child's safe return to the physical world. These acts take on a variety of forms, such as measuring a child to a saint, bending a penny over a child, and vowing to forgo eating a certain food. In 1293, William of Lonsdale embarked on a pilgrimage to the shrine of St. James of Compostela with his five-year-old daughter, Alice. During the trip, Alice stumbled into the road and died from a leg wound. William bent a penny over her body (supra denarium), measured her body for a candle

\footnotetext{
${ }^{234}$ Benedict of Peterborough, Materials for the History of Thomas Becket Vol. 2, 239: "Visne," ait, "fili, vivere?" "Volo," inquit, "pater mi."

235 Benedict of Peterborough, Materials for the History of Thomas Becket Vol. 2, 239; There is also an alternate account about the knight Jordan and death of his son by William of Canterbury. In the William of Canterbury story, Jordan's grief, like that of Hugh Scot, is only represented in an appeal to Thomas Becket to restore his son to life. See William of Canterbury, Materials for the History of Thomas Becket Vol. 1, 160-161; The invocation of Thomas Becket by a man named Robert of Fleming is also in the collection. He tells miracle compilers that he called upon the saint when his son died in a cave of water. However, there is not much else detail. William of Canterbury, Materials for the History of Thomas Becket Vol. 1, 522.
} 
(mensuravit), and vowed to go on pilgrimage to Thomas of Cantilupe's shrine in Hereford if she was resuscitated. According to the author, he fulfilled all his vows and his daughter was returned to the physical realm. ${ }^{236}$ In another Thomas of Cantilupe miracle, a child named Felicia drowned in a well and her father also measured her to the saint. ${ }^{237}$ William of Lonsdale performs religious acts in order to save his daughter, showing that, even though emotional rhetoric is absent from the account, love and sadness are expressed by his immediate attempts to revive her. Furthermore, by restraining his grief, he is able to perform the proper acts that will save her life.

Fathers also expressed grief by vowing to go on pilgrimage in exchange for resuscitation of a child. Making an oath to go on pilgrimage was a major aspect of the medieval spiritual journey for both men and women. Long-distance pilgrimage grew in popularity, especially with the lay nobility, after the Crusades. ${ }^{238}$ Shorter pilgrimages, too, increased between the eleventh and thirteenth centuries and by the later Middle Ages, saints' shrines dotted the landscape of Europe and the laity participated in pilgrimage, both near and far. Pilgrimage offered people "unmediated access to the divine," especially in times of distress. ${ }^{239}$ In one extremely poignant miracle from the Thomas Becket collection, William of Canterbury recounts a story about a pregnant

\footnotetext{
${ }^{236}$ Bolland, Acta Sanctorum, October 1, Section 646.

${ }^{237}$ Bolland, Acta Sanctorum, October 1, Section 643-644.

${ }^{238}$ Jonathan Sumption, Pilgrimage: An Image of Medieval Religion (Totowa: Rowan and Littlefield, 1975), 114-136.

${ }^{239}$ Leigh Ann Craig, Wandering Women and Holy Matrons: Women as Pilgrims in the Later Middle Ages, Studies in Medieval and Reformation Tradition, ed. Andrew Gow (Leiden: Brill, 2009), 8-10.
} 
woman from Hameldon named Margaret. He writes that she experienced an imbalance of humors, which caused her to have a nosebleed for several hours. The prolonged nosebleed, William of Canterbury explains, caused the nutriments reserved for the fetus to be depleted. As a result, Margaret is described as having "not a womb but tomb" (non utero sed tumulo), "not a son but a corpse" (non filius sed funus). Margaret mourned the loss of her newborn and suffered great pain as she tried to deliver the possibly stillborn child. The midwife could do nothing to help, so Margaret's husband, Thomas, seeing his wife in such despair and realizing that his unborn child was probably dead, said that he would prepare to go on pilgrimage to Thomas Becket's tomb, if Thomas Becket helped Margaret deliver the child. Although Thomas Becket allowed Margaret to give birth, the story does not have a happy ending. Instead of a healthy baby, she gave birth to a rotting infant, barely of human form (vix humanam forman habens). ${ }^{240}$ In another miracle that occurred in Stepney (near London) in 1485, a six-year-old boy drowned when he fell off a boat moored by the river. His body floated into the Thames for about one hour before his parents saw that he had gone missing. His father, William Granger, who loved the boy fervently (amore fervencior) and was of sad mind (animo tristior) because of the accident, vowed to not eat meat or fish (carnium quicquam vel piscium) until he could go on pilgrimage to Henry VI's shrine, in exchange for the boy's revival. ${ }^{241}$

The narrator of the Henry VI miracle attaches emotional terms to William Granger, such as "fervent love" and "sad mind," to demonstrate a strong father-son bond

${ }^{240}$ William of Canterbury, The Materials for the History of Thomas Becket Vol. 1, 226227.

${ }^{241}$ Grosjean, ed., Henrici VI, 116. 
and to show his distress after the drowning. Additionally, the detail about vowing not to eat meat and fish further reinforces the idea that William Granger is desperate to do anything to save his son. In the miracle about Margaret and her unborn child, the husband witnesses his wife's grief, and also worries about the health of his child himself. He takes this as his cue to rescue both of them. His decision to go on pilgrimage is a sacrifice that he makes for his wife and child, showing that he truly cares about both of them, and would grieve if his child perished. Both of these miracles again focus on emotional restraint. William of Canterbury shows Thomas' grief and worry through his vow to Thomas Becket. Similarly, the author shows William Granger's grief through a vow. His emotional restraint about the situation is even further implied because the author says that he is of "sad mind." In other words, he does not grieve outwardly, but inside, he is experiencing anguish over the death.

It is worthwhile to point out that, while all of the miracles above depict fathers willing to go above and beyond for their children, there are instances where parents do not fulfill their religious obligations, including the miracle given in the introduction to this chapter. Jordan, who after being elated that his son was revived by Becket water, delayed his vow to honor the saint during Lent. Because of this, the martyr appeared to a leper named Gimpe, who knew nothing about the situation. The martyr told him to warn Jordan that if he did not fulfil his vow he would soon bring forth evil (malum) to his household. ${ }^{242}$ When the leper gave the admonition to Jordan and his wife, they delayed their vow. As a result, they were struck with an illness, while their eldest son was

${ }^{242}$ Benedict of Peterborough, Materials for the History of Thomas Becket Vol. 2, 230231. 
punished with death. The wife pleaded with Thomas Becket to forgive them for their wrongdoings and reflected on the consequences of their sins, stating, "And look, we lost our son!" ${ }^{243}$ Here, again, we see the mother making a proclamation regarding culpability, even though both parents were responsible for not fulfilling the vow of pilgrimage. In the end of the story, both parents, not wishing to be punished further, embark on a journey to Thomas Becket's tomb to rectify their sins. ${ }^{244}$ While this miracle makes it seem as though parents did not truly care about their children because they were not willing to fulfill their religious oaths (or perhaps could not fulfil them immediately), it is more likely that these details were added into death accounts to show religious misconduct and the true power of saints,' rather than callous attitudes towards children. The story of Jordan not fulfilling his promise also underscores the idea that saints had the power to bring back parental grief if they were not worshipped correctly.

\section{IMMODERATE PATERNAL GRIEF IN MIRACLE STORIES}

As we saw from the examples above, paternal grief could be outwardly expressed. Yet, it was mostly done in privacy. Fathers did not attract the attention of neighbors or enter extreme states of mourning like Olivia and Ersandis in Chapter Two. However, sometimes authors of medieval miracle stories described fathers as being consumed with grief which was lasting and left them disoriented. One heartbreaking story about a man and the death of his beloved daughter is told by Benedict of Peterborough. He writes that,

\footnotetext{
${ }^{243}$ Benedict of Peterborough, Materials for the History of Thomas Becket, Vol. 2, 232: "et ecce, filium nostrum amisimus."

${ }^{244}$ Benedict of Peterborough, Materials for the History of Thomas Becket Vol. 2, 232.
} 
Cecilia, who lived in Plumstead, Norfolk was seemingly dead from cancer around the femur and was laid out for her funeral. In utter disbelief, her father, Jordan, who had thrown himself onto his bed because of the labor of his sadness, suddenly woke up shouting (Pater autem, qui se seorsum projecerat, vexatum dolore partier et labore, excitatus a somno cum clamore irruit):

It is not possible that my daughter is dead? [Nunquid mortua est filia mean?] $\mathrm{O}$ blessed Thomas, martyr of God, give me now my service, which once I devoutly paid to you; give me my service! Now it is an urgent necessity [Urget nunc necessitas]. Once I served you with devotion, before you were exalted with this world's honors [Olim tibi sedule servivi antequam saecumlaribus efferreris honoribus]; give my service to me! Remember, blessed martyr, how you were sick once in Kent in cleric Turstan's house, and what good service I gave you there. You were not able to taste wine, strong drinks, beer, or any liquor which was intoxicating; and I used to search the whole neighborhood to find you something which you could drink for the illness; give me my service! Then you had but one horse, and I took charge; give me, martyr, my service, remember all my labor, which I endured concerning you; give me my service, since you do not wish me to have served in vain [redde mihi servitium meum non indiges quod gratis tibi servierim]. ${ }^{245}$

${ }^{245}$ Benedict of Peterborough, Materials for the History of Thomas Becket Vol. 2, 235236: "Nunquid mortua est filia mea?...O beate Thoma, Dei martyr redde mihi nunc servitium meum quod tibi olim sedulous impendi; redde mihi servitium meum! Urget nunc necessitas. Olim tibi sedule servivi antequam sæcularibus efferreris honoribus; redde mihi servitium meum! Memento, beate martyr, quam infirmus dudum in Cantia in domo Turstani clerici exsititeris, qualiter illic tibi servierim. Vinum et siceram et cervisiam, et omne quod inebriare potest, gustare non poteras; et ego tibi per totam viciniam serum perquirebam, quod biberes; redde mihi servitium meum! Unicum tunc habebas equum cuiius et ego curam agebam; redde mihi, martyr, servitium meum, reminiscens omnium laborum, quos circa te perpessus sum; redde mihi servitium meum!" 
He continued screaming similar pleas into the night (In huiusmodi clamoribus fere dimidium noctis expendit), so much so that he had to stop because his windpipe became hoarse (ut raucitas arctaret arterias) from the exertion. ${ }^{246}$ Within the dialogue, Benedict of Peterborough sets up an image of complete sorrow and devastation. Jordan responds to Cecilia's death with shouts, prayers to Thomas of Becket to revive his daughter in exchange for religious service, and by essentially passing out from overwhelming grief which weakens his body. Furthermore, Benedict of Peterborough makes it clear that Jordan is not willing to accept his daughter's death. During his plea to Thomas Becket, he appears angry that the holy man has not restored his daughter immediately in light of his past loyalty to him. This is similar to the plea of Hugh Scot in the Benedict of Peterborough account. The interaction between Jordan and the saint conjures up an image of an unfulfilled reciprocal relationship. We learn that Jordan provided service for the holy man, but feels as though the service in not being returned in his time of need. He recalls how much he did for Thomas Becket in the past, including helping him find a horse and taking care of him during an illness. By adding this information into his plea, it appears that he almost points a finger at Thomas Becket, suggesting that he may not remember all of these services because of his now revered status. He begs Thomas Becket to remember his loyalty and prove that his service was not in vain. This passage is also reminiscent of "humiliation of the saint" rituals, where people would mistreat or even yell at saints' relics when holy figures failed to come to their aid. Geary explains that these rituals involved "status reversal in the proper human-divine hierarchy" and

\footnotetext{
${ }^{246}$ Benedict of Peterborough, Materials for the History of Thomas Becket Vol. 2, 235236.
} 
were necessary to "keep the spiritual powers benevolently disposed toward human society. ${ }^{247}$ In the excerpt, there is indeed a role reversal of status. Jordan angrily points out that Thomas Becket has not proven his sanctity because he does not revive his daughter. The urgency applied to Jordan's tone bears a striking resemblance to that of the mothers of Chapter Two. His mourning is by no means restrained.

Cecilia's mother's response to her death is interesting because it is the opposite from what we see with Jordan, or any of the other mothers thus far. When Jordan wakes up from his grief-stricken stupor and asks, "It is not possible that my daughter is dead?" his wife simply replies, "In fact, she is dead" (Revera, mortua est). ${ }^{248}$ This is a very uncharacteristic response from a mother in a miracle account. Jordan's wife does not mourn with him; she does not shed tears or promise to perform a religious act, besides seeming to want her daughter to receive a proper Catholic burial. What is more, she makes no effort to comfort her husband during his episode of lamentation. In fact, her perfunctory response to his grief suggests that she believes that he is overreacting about the situation. That is to say, she is the voice of reason in the moment, while her husband is in denial and continues to grieve throughout the night about a death he refuses to accept.

Another Thomas Becket miracle, this one authored by William of Canterbury, highlights another instance of extreme mourning involving a father. Alan of Burton, was waiting for his wife, Eve, to give birth, when misery struck. The midwives (obstetricum) rushed out of the birthing room, crying that his child was stillborn. Hearing the

${ }^{247}$ Geary, Living with the Dead, 95, 102.

${ }^{248}$ Benedict of Peterborough, Materials for the History of Thomas Becket Vol. 2, 235. 
devastating news, Alan of Burton, William of Canterbury says, forgot his manhood (virum oblitus) and howled like a woman (fermineos inculcate ululatus). He then went on to plea for help:

Have pity [Miserere], Saint Thomas! Save the boy...Have mercy, Saint Thomas! Why is life denied to a newborn, for whom the time of birth was administered? Why was the joy of conception, the hope extended, only to have grief arise as time goes on? [Quos letificabat in conceptu, spe dilatabat, processu temporis cur moestitia dejicit duntaxat in ortu?] Why did the mother carry him so many months, only to give birth to him dead? ${ }^{249}$

After his lament, he continued to cry out for a while (Pater itaque diu clamante) and his son was eventually revived like the roar of a young lion (excitatus est filius, tanquam catulus rugitu leonis). ${ }^{250}$ In a miracle located in Ferring in Sussex, a knight is depicted as reacting similarly when his wife, Ansfrid, gives birth to a deceased child. Benedict of Peterborough writes, "The time for the woman to give birth had passed, however, and she was not able to give birth. She had conceived a son of whom she was not the future mother, but the grave. For fifteen days, the fetus did not move in the mother's uterus." ${ }^{251}$

\footnotetext{
${ }^{249}$ William of Canterbury, Materials for the History of Thomas Becket Vol. 1, 346: "Miserere, sancta Thoma!...Salva puerum. Pro puero et cum puero utrumque votis astringo parentem. Miserere, sancte Thoma! Cur nato negate est vita, cui procurata sunt tempora nascendi? Quos lætificabat in conceptu, spe dilatabat, processu temporis cur mostitia dejicit duntaxat in ortu? Cur mater vivum tot mensibus portavit, ut mortuum pareret?"

${ }^{250}$ William of Canterbury, Materials for the History of Thomas Becket Vol. 1, 346. The simile tanquam catulus rugitu leonis is used to convey the sense that the newborn, like a baby lion cub, yelped or breathed air for the first time once the restoration to life took place.

${ }^{251}$ Benedict of Peterborough, Materials for the History of Thomas Becket Vol. 2, 196: "Mulieri autem impletum est tempus pariendi, et parere non potuit; filium quidem
} 
Astounded and desperate (obstupuit, desperata), the knight (paterfamilias) asked, "What do we do [Quid agimus?]?" "What do we do [Quid agimus?]?" "We sit despairing and do not remember the martyr of Canterbury." ${ }^{252}$ At that moment, the knight,

seizing a string for his son, with an invocation of his name [Thomas Becket], he measured the dying, promising the martyr a service of oblations, because she herself [the mother] was not strong enough to make the vow...thereafter, she gave birth, but to a lifeless fetus so mushed that it resembled meat cooking in a hot pot. $^{253}$

The knight's grief, which manifests as panic, is evident in the story. At first, his grief overcomes him and he is not sure how to handle the death, but then realizes that he can ask for divine intervention.

conceperat, cuius non mater esset future sed sepulchrum. Diebus quindecim se fœtus in utero materno non moverat."

${ }^{252}$ Benedict of Peterborough, Materials for the History of Thomas Becket Vol. 2, 196: "desperantes sedemus, et martyris Cantuariensis non reminiscimur."

${ }^{253}$ Benedict of Peterborough, Materials for the History of Becket: Vol. 2, 196: "et arrepto filo, cum invocatione nominis eius morientem commetitur, spondens martyri munus oblationis, quod illa vovere non valebat...sed fœtum exanimem itaque decoctum ut carnis in olla ferventi decoct instar videretur habere." Another miracle from the Thomas Becket collection that shows the concern of a father. He recounts that a woman named Elinor, the wife of a knight, who lived in Oxford, was not just close to giving birth, but closer to death (sed vicinior morti), because she was too young to become a mother (Nam nondum erat eius aetatis ut mater fieri deberet). Her husband, feeling compassion for her, hung a relic of the martyr around her neck (Unde vi rei compatiens, praecipue quod imtempestivae conceptionis pericula pateretur, collo eius reliquias martrics appendit). His wife then gave birth to a healthy boy and William of Canterbury writes that, because of his act, he saved two in one person (duos in uno homine conservavit). While this story does not directly tell us the knight's feelings about child death, or even end in child death, it highlights the love he has for his wife and unborn child. Furthermore, the story shows that he is willing to perform a religious act in order to avoid any grief that may have come, had his wife or son died in childbirth. See William of Canterbury, Materials for the History of Thomas Becket, Vol. 1, 469-470. 
Another case where a man is disoriented because of his grief is found in the Henry VI collection. A girl named Beatrice, aged three, died when a tree trunk fell on her as she played with other children. When her father found her, he became pale (palluit) and his heart stung with pain (corde que concussus doloris spiculo ammoto). Then, the fountains of his eyes erupted with tears (Ac demum erumpentibus oculorum fontibus) and he handed the child off to his wife and she took her to the church to say prayers over her body. ${ }^{254}$ Similar to the knight, the father of Beatrice grieves so much that he does not know what to do when she dies.

The knight from Ferring is not portrayed in the best light because of his overwhelming grief. His sadness causes him to lose sight of religious protocol, in the eyes of the author. The same goes for Beatrice's father. He is so overwhelmed with emotion, that he has to pass her off to his wife in order to save the child. Both fathers become so disoriented that they do not call upon Thomas Becket or Henry VI, at least not right away in the case of the knight. William of Canterbury also portrays Alan of Burton's immoderate grief in a negative light. William of Canterbury begins and ends Alan of Burton's plea to Thomas Becket with words of lamentation (ululatus, clamante), which highlights the intensity of his grief. The imagery of a parent "howling" as a reaction to child death was also seen in Chapter Two in the miracle story about Margery, who loosened her swaddling bands and fell out of her cradle. Like Margery's mother, Alan of Burton not only cries out in pain, but his sadness is so intense that it transforms him into something other than himself. In a series of rhetorical questions, he explains his

\footnotetext{
${ }^{254}$ Ronald Knox and Shane Leslie, eds. and trans., The Miracles of King Henry VI (Cambridge: Cambridge University Press, 1923), 52-53.
} 
misery and anger about the situation to Thomas Becket. He wonders why his wife has to live with the fact that she carried a child for months, only to have him die; he wonders why they were even subjected to the idea of adding another member to the family, if they would ultimately have their hopes dashed at the moment of birth; and most of all, he wonders why an infant would have to die before experiencing life.

He describes Alan of Burton's wails as being "womanly." Alan of Burton grieves excessively causing him, according to William of Canterbury, to participate in a complete gender-reversal. He no longer holds the title of the head of household because his grief has made him vulnerable. By adding in this detail, William of Canterbury presents Alan of Burton's reactions to child death as being atypical for a man. Thomas of Monmouth, a Benedictine monk from Norwich, also used grief to distinguish between male and female. When discussing the death of the twelve-year-old William of Norwich, he writes that William's mother lamented through the streets and open places (per vicos et plateas). To Thomas of Monmouth, this type of behavior was womanly (muliebris) and rash (temerarius). ${ }^{255}$

The description of Alan of Burton losing his "manliness" in the wake of his grief, and the portrayal of Beatrice's father and the knight from Ferring's disorientation caused of grief, sheds some light onto what medieval authors thought about immoderate male grief: being consumed with grief could make one lose sight of religion. Outwardly expressed grief was acceptable. It was evidence of the attachments men had to their children and the result of those attachments breaking at the time of death. However,

\footnotetext{
255 Thomas of Monmoth, The Life and Miracles of St. William of Norwich, ed. Augustus
} Jessop (Cambridge: Cambridge University Press, 1896), 42. 
excessive grief, Ralph Houlbrouke states, showed lack of faith, and also sincerity. ${ }^{256}$ While the accounts do not necessarily give off the connotation that paternal grief was insincere, they do highlight the idea that their grief was distracting from religion.

Beatrice's father and the knight lose sight of what they must do after child death: trust in God and call for divine aid. Naama Cohen Hanegbi explains that unhealthy mourning, especially caused by the death of children, was a major concern in the medieval world. As a result, sermons on Job's acceptance of child death were popular, especially in Italy. The sermons, Hanegbi argues, highlighted that people should accept God's will and not fall into grieving episodes where they questioned death. ${ }^{257}$

Excessive grief also blurred gender roles and turned household hierarchy's upside down. Herlihy explained that the word familia or "family" in classical Latin referred to "everything and everyone under the authority of the household head," and this definition transferred into the Middle Ages. To Herlihy, the head of household was chief of the domain. ${ }^{258}$ Hanawalt, on the other hand, argued that the paterfamilias "did not hold the sway over his family" as people once thought. ${ }^{259}$ Peasant families went into a "partnership" marriage. ${ }^{260}$ This did not mean that wife and husband maintained the same household status or that this partnership worked in every marriage. Women assumed the

\footnotetext{
${ }^{256}$ Ralph Houlbrooke, Death, Religion, and the Family in England, 1480-1750 (Oxford: Oxford University Press, 1998), 225.

${ }^{257}$ Naama Cohen-Hanegbi, Caring for the Living Soul: Emotions, Medicine and Penance in the Late Medieval Mediterranean (Leiden: Brill, 2017), 183.

${ }^{258}$ Herlihy, Medieval Households, 2-3.

${ }^{259}$ Hanawalt, The Ties that Bound, 10.

${ }^{260}$ Hanawalt, The Ties that Bound, 219.
} 
role of materfamilias, which put them largely in charge of the domestic sphere, whereas the role of paterfamilias remained at the top of the household hierarchy. Men were supposed to uphold this position during times of crisis in order to maintain harmony within the household and also keep the household economically viable. Of the nature of men, Bartholomeaus Anglicus wrote that they were to "take charge, and keep guard, over his wife and children." ${ }^{261}$ Therefore, letting grief blur gender roles could lead to the demise of the family unit. This may be why Benedict of Peterborough depicted Jordan's wife as acting so coldly when he started to express extreme distress about his daughter's death. Jordan's wife assumed the role of the head of household, since her husband took on the emotions of a woman. In other words, she had to be strong, for the family, in light of the death because her husband was not in a good state emotionally. Another reason she may have acted in such a way, was to show her disapproval for her husband's abandonment of his role of paterfamilias.

The miracle accounts presented here would have acted as didactic literature for fathers, just as they would have for mothers. Instead of pointing out ideal parenting duties or warning fathers about neglect, miracle writers used grief in their rhetoric to put forth the message that there were gender-appropriate forms of grieving. Public paternal grief was acceptable, as long as it was not excessive. Excessive male grief turned the medieval household upside down, blurring gender roles. In addition, it could lead someone to turn away from faith.

${ }^{261}$ Bartholomeaus Anglicanus, On the Properties of Things, 307: "he takep so pe charge, pe warde... of his wif pat is modir of children." 


\section{PATERNAL GRIEF IN THE PEARL AND BROME ABRAHAM AND ISSAC}

Immoderate paternal grief is also found in poetry, such as the fourteenth-century Middle English anonymous poem, the Pearl. The Pearl is an alliterative dream vision rich with emotional dialect and imagery throughout each stanza. According to Malcolm Andrew and Ronald Waldron, the "Pearl is a poem about transformation," both mental and spiritual. ${ }^{262}$ The main character of the poem is an unamed man, or the "Dreamer" as Pearl scholars call him, who is overcome with sadness over the loss of his daughter, so much so that he appears "obsessed with grief." ${ }^{263}$ The Dreamer narrates most of the dialogue and sets the tone for the gloom that he feels over his daughter's death at the start of the poem. He begins with a description of his daughter, then transitions into an explanation of her fate. His grief over the death of his daughter is mentioned within the first ten lines of the poem. He recalls,

Pearl, pleasing to a prince's day, / Set elegantly in gold so clear / In all the Orient, I firmly say, / I have not found one to compare, / So round, so radiant in array, / So small, so smooth her sides appeared, / Wherever I judged gay gems / I set her apart as unique. / Alas! I lost her in a garden / Through the grass to the ground she tumbled away from me. / I suffer, wounded by unrequited love / For that special pearl without a spot. / Since from that spot it sprang from me / Often have I waited, in hope to see / That pearl that once could drive away my sorrow / And fill my soul with happiness / But that does nothing but press on my heart harshly, / My breast swells and burns painfully. / Yet there was no song that seemed so

${ }^{262}$ Andrew and Waldron, eds., The Poems of the Pearl Manuscript, 30.

${ }^{263}$ Andrew and Waldron, eds., The Poems of the Pearl Manuscript, 30. 
sweet / But then my thoughts ran free / To think her color so clad in dirt. / O

Earth! you have marred her purity, / My special pearl without a spot. ${ }^{264}$

In the first line of the poem, the man likens his daughter to a precious gem: a pearl. She is perfect in every way, and unlike any other pearl in the world. She is the roundest, smallest, smoothest, and shiniest pearl (so rounde, so reken in uche arraye, so small, so smothe) that he's ever seen. The father's complete adoration for his child shines through with these praising descriptors, making the story about his loss more poignant. He also employs repetition throughout the lines in order to emphasize his daughter's youth and the unexpectedness of her death. The phrase "wythouten spot" is repeated to allude to her psychical and spiritual purity at the time of her death, making the story that unfolds even more tragic. ${ }^{265}$

The father moves on from reminiscing about his daughter's life to discussing her untimely death, where his overwhelming grief takes over. He uses the metaphor of losing

\footnotetext{
${ }^{264}$ Sarah Stanbury, ed., Pearl, Middle English Texts Series. University of Rochester Robins Library Digital Projects: http://d.lib.rochester.edu/teams/text/stanbury-pearl. Lines 1-24: "Perle, pleseaunte to prynces paye / To clanly clos in golde so clere; / Oute of orient, I hardyly saye. / Ne proved I never her precios pere. / So rounde, so reken in uche araye, / So small, so smothe her sydes were, / Queresoever I jugged gemmes gaye / I sette hry sengeley in synglure. / Allas, I leste hyr in on erbere; / Thurgh gresse to grounde hit fro me yot. / I dewyne, fordolked of lu-daungere / Of that privy perle wythouten spot. / Sythen in that spot hit fro me sprange, / Ofte haf I wayted, wyschande that wele / That wont was whyle devoyde my wrange / And heven my happe and al my hele. / That dos bot thrych my herte thrange, My bresete in bale bot bolne and bele. / Yet thought me never so swete a sange / As stylle stounde let me stele; / Forsothe, ther fleten to me fele / To thenke hir color so clad in clot. / O moul, thou marres a myry juele, / My privy perle wythouten spotte."

265 That the daughter died at a young age is later confirmed in line 483 of the poem when the father tells his daughter that she lived not two years on earth (Thou lyfed not two yer in oure thede).
} 
his precious pearl in a garden (Allas, I leste hyr in on erbere) to describe his child's passing. The pearl, he says, suddenly "sprang" from him, again, pointing out the unexpected nature of his daughter's death, and got lost in the garden's grass. The once spotless pearl was corrupted by soil (i.e., the girl's body is interred in a grave). Alongside the grim imagery that this description creates, emotional language is generously intertwined throughout the verses by the father himself to describe his feelings. He describes himself as suffering from unrequited love beyond repair (I dewyne fordolked of luf-daungere). In other words, now that his daughter has perished, he can no longer feel her physical love on earth. Moreover, he states that he is longing for his daughter's return in order to end his sadness (Oft haf I wayted, wyschande that wele / That wont was whyle devoyde my wrange). This never happens, leaving him in constant pain. Furthermore, he describes himself as experiencing burning and swelling in his chest (That dos bot thrych my herte thrange, / My breste in bale bot bone and bele). His grief manifests both physically and mentally. Grief is what he has become and it has negative consequences. He feels sadness in his mind, all he thinks about is his daughter and her passing. Grief also courses through his body and harms him. It causes his chest to burn and swell, as he realizes that he will never see his child again.

The theme of all-consuming grief continues into the next section of the poem. Even though much time has passed (Ther wonys that worthily, I wot and wene), the man cannot escape his grief, because it has attached itself to him and now lives within his body. ${ }^{266} \mathrm{He}$ goes into the garden where his pearl was once lost and, still fueled with anguish, he says,

\footnotetext{
${ }^{266}$ Stanbury, ed., Pearl, Line 47.
} 
A desolating grief lay deep in my heart / Though I ought to seek reason for comfort, / I mourn my pearl which there it is locked / I swiftly fought arguments of reason, / And even though the nature of Christ should have taught me comfort/ My wretched sorrow will not go away. ${ }^{267}$

The Dreamer admits that he that he should reason his way out of mourning for his daughter, but he simply cannot stop. What is more, his grief is so powerful that he has lost sight of his faith in Christ. He cannot find consolation in Christ, because he, the jeweler, treasures his pearl more than religion. Emotion, specifically grief, conflicting with proper worship becomes the next focus of the poem. Exhausted by his continual grief in the garden, the man falls into a deep sleep and embarks on a dream vision that forces him question his earthly and spiritual priorities. ${ }^{268}$ Images in the Pearl manuscript alongside the poem depicts the Dreamer falling asleep in the garden where he lost his daughter. He lays in the grass, near trees. During the dream-vision sequence, the man finds himself in a magnificent garden, with beautiful trees and cliffs:

From that spot my spirit sprang in space / Let my dreaming body lie. / My soul in God's good grace / In a journey where wonders multiply. / Towards a forest I turned my face / Where rich rocks I could see. / The light of which no one could believe / With all that glorious splendor bright, / In splendor shone those down

\footnotetext{
${ }^{267}$ Stanbury, ed., Pearl Lines 51-56: “A deuely dele in my hert denned / Thagh resoun sette myseluen saght. / I playned my perle that ther was spenned / Wyth fyrte skylles that faste faght, / that kynde of Kryst me comfort kenned. / My wreched wylle in woe aye wraghte."
}

${ }^{268}$ All Pearl manuscript images are from University of Calgary Libraries and Cultural Resources Digital Collections: http://contentdm.ucalgary.ca/digital/collection/gawain/search 
land sides / Clear did those cliffs their nature show, / And bright about them, woodland rides / With tree-trunks blue as indigo. ${ }^{269}$

The garden he wakes up in is beautiful. It is bright, has beautiful cliffs and rock formations, but even in all its beauty, he senses that there is something better beyond the confines of the garden. He feels as though Paradise is within reach (For I thought that Paradyse / Was the over gayn tho bonkes bade), but for whatever reason, he cannot get a good view or cross a stream to investigate further. ${ }^{270}$ Image 7 depicts this part of the poem. The man stands at one end of the stream, not able to cross over to what he thinks is Paradise. As he moves around the garden, he suddenly sees a beautiful maiden Mesmerized, he states,

And at its foot [the foot of a cliff] a child so fair / More courtly a maiden there was none. / A golden mantle she did wear; / I knew her well from times long gone, / And for a long time I looked at her / The longer I did, I knew her more and more. / The more I examined that lovely face, / That lovely figure so long unseen, / Such gladness did come to me..$^{271}$

\footnotetext{
${ }^{269}$ Stanbury, ed., Pearl Lines 61-76: "Fro spot my spyryt ther sprang in space / My body ther bod in sweven. / My goste in Godes grace / In aventure ther mervayles meven. / I ne wyste in this worlde quere that hit wace / Bot I knew me keste ther klyfes cleven. / Towarde a foreste I bere the face / Where ryche rokkes were to dyscreven. / The light of hem might no mon level, / The glemande glory that hem glent, / For wern never webbes that wyyes weven / Of half so dere adubemente. / Dubbed wern alle tho downes sydes / Wyth crystal klyffes so cler of kynde; / Holtewodes bright aboute hem bydes / Of bolles as blwe as ble of Ynde."

${ }^{270}$ Stanbury, ed., Pearl Lines 37-38.

${ }^{271}$ Stanbury, Pearl Lines 161-193: "At the fote therof sete a faunt, / A mayden of menske ful debonere. / Blysnande whyt was hyr bleaunt. / I knew hyr wel, I had sen hyr ere. / The lenger, I knew hyr more and more. / The more I frayste hyr fayre face, / Her figure fyn quen I had fonte, / Suche gladande glory con to me glace."
} 
The man immediately breaks away from his grief when the maiden appears. As he gazes upon her, an air of familiarity strikes him. She is perfect, donning pearls. He asks, O Pearl, adorned in pearls / Are you my pearl for whom I cried, / For whom I grieved alone at night? / I have spent much time sighing over you / Since into the grass you left my sight. / Sorrow and grief with me reside / While you remain in true delight / In Paradise. / What fate did now my pearl experience / And left me here in grief? / Since you were taken from my side / I am a joyless jeweler. ${ }^{272}$

While the maiden indeed turns out to be an apparition of his deceased daughter, she does not respond to her father's grief as one might expect. She patiently listens to his emotionally-packed speech, but instead of offering consolation in regards to her death, she claims that the reason for his grief is unnecessary. Scolding him, she yells, "Your joy in a gem to you so dear, / I think you do confuse yourself. / Jeweler, you joke! / You lack all sanity! / Your thought has no reason nor rhyme." ${ }^{273}$ More importantly, she says, that he has been mistaken about losing her this whole time. She is not lost or decaying in the ground, she is still a spotless pearl. In other words, believing that death brings about complete destruction and finality is false, and it leaves her little to admire about her father, who clearly does not understand spiritual truth: "I give that jeweler little praise /

${ }^{272}$ Stanbury, ed., Pearl Lines 241-252; "O perle, in perles pyght, / Art thou my perle that I haf playned, / Regretted by myn one on nyghte? / Much longeyng haf I for thee layned / Sythen into gresse thou me aglyght. / Pensyf, payred, I am forpayned, / And thou in lyf of lykyng lyghte / In Paradys erde, of stryf unstrayned. / What wyrde has hyder my juel vayned / And don me in thys del and gret daunger? / For we in twynne wern towen and twayned / I haf ben a joyles jueler."

${ }^{273}$ Stanbury, ed., Pearl Lines 266-267, 289-291: "Thy joy for a gemme that thee was lef, / Me think thee put in a mad propose...Jueler, Wy borde ye men? / so madde ye be! / That words has thou spoken et ene." 
Who trusts the witness of his eye, / And much to blame, and lacking grace, / Who thinks our Lord would make a lie." ${ }^{.74}$ At this point in the poem, it becomes clear why the man cannot cross the stream or see Paradise at the beginning of his dream vision. When referring to Paradise, the maiden asserts, "But entrance there you cannot gain, / To walk there you have not the power / Unless you are without stain."275 The man's grief has caused him to forsake religion, which makes him a sinner and prohibits him from obtaining any glimpse of salvation. He is not even able to approach his daughter too closely, because she has been saved, while he has not. Making this fact more poignant is another image in the manuscript, which shows the father and maiden reaching for each other over the stream in the garden. This heartbreaking image depicts the maiden standing just beyond the city gates of Paradise, where her father is not allowed access. Her father, still standing in the garden, looks towards her, unable to move. If the father trusted in God at the time of her death, he would be able to join her in Paradise someday, but since he does not and continues to focus on his grief, an emotion that ties him down to the earthly realm, he will never be able to cross the stream.

Chastising the man for his grief over child death does not end here. The maiden goes on to explain to her father that he must turn his life around in order to be saved, starting with how he is reacting to her death. He must not grieve about minor losses. Instead of grieving, she encourages him to "bless [himself], / And praise God all the time,

${ }^{274}$ Stanbury, ed., Pearl Lines 301-304: "I halde that jueler lyttel to prayse / That loves wel that he ses wyth yye, / And much to blame and uncortoyse / That leves oure Lorde wolde make a lye."

${ }^{275}$ Stanbury, ed., Pearl Lines 971-973: "Thou may, bot inqyth not a fote/ To stretch in the strete thou has no vygour / Bot thou wer clene wythouten mote." 
come weal or woe."276 In other words, he should focus on his spiritual health and continue to worship during both good and bad times. If he does this, he will not only be able to enter Paradise himself, but also have the chance to reunite with his child. To further reinforce her point, she tells the parable of the Pearl of Great Price found in Matthew 13: 45-46:

Jesus called his followers, / And said no man His realm could win / Unless he came there as a child; / Or else, he could never enter. / The harmless, true, and undefiled, / Without a spot or stain of sin, / These, when they knock are not sent away; / Quickly do men unlock the gate. / Their bliss will not cease there, / So a precious pearls the jeweler sought, / And sold all his goods and clothes / To buy a pearl without a spot. / This spotless pearl, whose price was dear, / For which that jeweler gave up all he had, / Is like the realm of Heaven clear, / So says the Lord of field and flood, / For it is spotless, pure and clear, / Endlessly round, serene of mood, / And owned by those who are righteous. ${ }^{277}$

In the parable above, heaven is compared to a pearl. The pearl is pure, perfect, and priceless, sharing the same qualities as heaven. Christ urges his followers to trade in earthly "things" in order to obtain the pearl (i.e., salvation). A jeweler, hearing this

\footnotetext{
${ }^{276}$ Stanbury, ed., Pearl Lines 341-342: "thyseluen blesse, / And love God in wele and wo."
}

277 Stanbury, ed., Pearl Lines 721-739; "Jesu con hym Hys mylde / And sayde Hys ryche no wyy myght wynne / Bot he com thyder right as a chylde / Other elles nevermore com therinne. / Harmless, trwe, and undefylde, / Wythouten mote other mascle of sulpande synne; / Quen such ther cnoken on the bylde, / Tyt schal hem men the gate unpynne. / Ther is the blys that con not blynne / That the jueler soghte thrugh perre pres / And sold all hys goud, bothe wolen and lynne, / To bye hym a perle was mascelles. / This makelles perle, that boght is dere, / The joueler gef fore alle hys god, / Is lyke the reme of hevenesse clere / So sayde the Fader of folde and flode / For hit is wemles, clene, and clere, / Ande endeles rounde and blythe of mode, / And commune to alle that ryghtwys were." 
speech, gives up all of his treasures in order to buy the thing that matters most: the pearl. In the dream vision, the parable of the pearl is also an allusion used to criticize the father for grieving as much as he does because he loses sight of the spiritual pearl (heaven) and focuses on the earthly pearl (his daughter). By the end of the poem, the man realizes the error of his ways, and while he admits that he will not be able to stop grieving for the death immediately, he acknowledges that he must perform penance for his behavior.

There are many theories as to what this poem symbolizes. Scholars such as Lynn Staley posit that the grief in this poem is more about the message of foregoing earthly wealth, rather than commentary on grief and child death. ${ }^{278}$ Others assert that grief in the Pearl alludes to spiritual rebellion and shows that "grieving becomes a bridge to wisdom. ${ }^{279}$ Christopher Daniell, on the other hand, contends that the Pearl can tell us about reactions to child death. ${ }^{280} \mathrm{I}$ argue that, while this poem can have a number of meanings, it can tell us about gendered expectations about emotional expression associated with child death. The poet employs the emotion of grief throughout the poem to point out the error of the Dreamer's ways. The Dreamer becomes so overwhelmed with grief that it distracts him from the only thing that matters: religion. His daughter even scolds him for letting himself be consumed with the thought of her death. This

\footnotetext{
${ }^{278}$ Lynn Staley, "Pearl and the Contingencies of Love and Piety," in Medieval Literature and Historical Inquiry: Essays in Honor of Derek Pearsall, ed. Derek Ares (Woodbridge: Boydell \& Brewer LTD, 2000), 109.

${ }^{279}$ Zbigniew Bialas et al., eds., Culture and the Rites/Rights of Grief (Newcastle upon Tyne: Cambridge Scholars Publishing, 2013), 5.

${ }^{280}$ Christopher Daniell, Death and Burial in Medieval England 1066-1550 (London: Routledge, 1997), 64.
} 
critical view of grief falls in line with the fathers who have episodes of excessive grieving in the miracle stories presented above.

The conflict of immoderate emotional expression vs. religion is also present in the Brome Abraham and Isaac mystery play. Rosemary Woolf points out that "In the Middle Ages it would have been more difficult for the story of Abraham's sacrifice to escape the eyes and ears of anybody, however uninterested he might be in it," with his sacrifice "commonly known as a type of Crucifixion," which was often referred to in sermons, artwork, and other devotional texts. ${ }^{281}$ She goes on to argue that the biblical version of the story portrays Abraham as the troubled main character, who must decide whether or not to sacrifice his son in the name of God. Isaac, in this version, is merely "an object of sacrifice," who has no agency. ${ }^{282}$ In contrast, the author of the Brome play, according to Woolf, depict Abraham as being less of a central character in the sacrifice, with Isaac as the main hero of the drama. Woolf also posits that Abraham appears unsympathetic to the choice that he must make in comparison to the biblical version. ${ }^{283}$ Although Isaac does take on a more prominent role in the play and convinces his father to obey God, I argue that Abraham is not as indifferent to his son's death as Woolf argues. Rather, his sadness over the sacrifice is showcased, for the most part, by the loyalty that he shows to his son and the grieving he experiences when he realizes that he must follow through with the act.

${ }^{281}$ Woolf, Art and Doctrine, 51-52.

${ }^{282}$ Woolf, Art and Doctrine, 49.

${ }^{283}$ Woolf, Art and Doctrine, 50. 
Before analyzing the play, we must first examine the description of the sacrifice in Genesis 22: 1-19. In contrast to the play, God narrates the sacrificial story, including Abraham's feelings towards his son. In this version, the bond between father and son is downplayed, with God only mentioning that Abraham must sacrifice the Isaac, the son who he "lovest." 284 No other emotional descriptors are found in the rest of the verses. Abraham hears God's command and unflinchingly agrees to offer Isaac as a sacrifice for the faith. Even at the time of sacrifice, he does not waiver in his decision: "And they came to the place where God had shown him, where he built an altar, and laid the wood in order upon it: and when he had bound Isaac his son, he laid him on the altar upon the pile of wood. And he put forth his hand and took the sword, to sacrifice his son." 285 Words denoting grief are not present in the verses. Still, a sense of pathos about the death of a child is still invoked with the repetition of the fact that Abraham must kill his own son in back-to-back verses. While the play also emphasizes this fact, the lack of grief in the biblical version is in stark contrast to the play which will be addressed below, where Abraham's sadness is described in detail and is clearly depicted as struggling with the notion of child death by his own hands.

Written sometime in the fifteenth century by an unknown author, The Brome Play of Abraham and Isaac begins with Abraham thanking God for all that he has given him, including the gift of his son, "You have given me both land and rent, / And my livelihood you have sent me. / I thank you highly for it all. / In my age you have granted this, / That this young child with me shall live. / I love nothing so much, indeed, / Except you, dear

${ }^{284}$ Douay-Rheims, Genesis 22: 3: drbo.org.

${ }^{285}$ Douay-Rheims, Genesis 22: 9-10: drbo.org. 
Father of bliss, / As Isaac here, my own sweet son."286 Immediately, the narrator points out Abraham's strong bond with Isaac. He loves Isaac more than anything, besides God. This is similar to the Dreamer talking about how much he loves his daughter at the beginning of the poem. Unbeknownst to Abraham, he will soon be asked to sacrifice his son for God, without any explanation. The author of the play foreshadows the sadness that Abraham will experience by providing a brief interaction between Abraham and Isaac right before Abraham is asked to sacrifice his child.

Abraham: Now come on, Isaac, my own sweet child, / Let us go home to take our rest.

Isaac: Abraham, my father so mild, / I am ready to follow you, / both early and late.

Abraham: Come on, sweet child, I love you the best / out of all the children I have ever had..$^{287}$

The passage demonstrates to the audience that Abraham not only cherishes his son, but also that Isaac trusts and loves his father, making the situation at hand even more grim. After this moment, God orders Abraham to sacrifice Isaac, to which Abraham pleads, I had rather, if God be pleased, / Forsake all the goods that I have / Than have my son Isaac be dead. / So the Lord in heaven can save my soul. / I have never loved

\footnotetext{
${ }^{286}$ Coldewey, ed., Early English Drama Lines 3-5, 11-15; “Thow hast goffe me both lond and rent, / And my lyvelod thow hast sent me; / I thanke thee heyly evermore of all. / In my age thou hast grantyd me thys, / That thys yowng chyld wyth me schall won; / I love no thyng so mych, iwysse, / Excepe thine owyn selffe, der Fader of blysse, / As Ysaac her, my owyn swete son."

${ }^{287}$ Coldewey, ed., Early English Drama Lines 26-32: Abraham: "Now cum on, Ysaac, my owyn swet chyld, / Goo we hom and take owre rest." Isaac: "Abraham, myn fader so myld, / To folowe yow I am full prest, / Bothe erly and late." Abraham: "Cume on, swete chyld, I love the best / Off all the chyldren that ever I begate."
} 
a thing so much on earth, / And now I must go kill the child. / O, Lord God, my conscience is strongly moved! / And yet, my dear Lord, I am painfully afraid / To do anything against your will. ${ }^{288}$

At the start of the dialogue, Abraham admits that he is afraid to disobey God's wishes; however, rather than stoically fulfilling God's request like in the biblical version, Abraham wishes that he could give anything else up in the place of the sacrifice. Abraham reasons that he must go on with the sacrifice, but continues to express grief through his words and mannerisms up until he tells Isaac about God's request. Abraham summons Isaac, who initially thinks that they are sacrificing an animal. Abraham laments Isaac's willingness to follow him blindly, not knowing his fate, and states that it "ruins his heart," causes "his heart to break into two pieces," and "fills his heart with woe."289 These descriptions are reminiscent to pain of the father in the Pearl, who claims that his chest hurts because of his all-consuming grief.

Abraham's grief is so apparent that Isaac begins to notice his father's odd behavior and asks, "Now, father, why do you seem so sad?" "Why do you mourn more and more?." ${ }^{290}$ Eventually, Abraham reveals that he must sacrifice Isaac to God. Initially

\footnotetext{
${ }^{288}$ Coldewey, ed., Early English Drama Lines 76-80: "I had lever, yf God had be plesyd, / For to a forbore all the good that I have / Than Ysaac my son schuld a be desessed, / So God in Hevyn my sowll mot save! / I lovyd never thyng so much in erde, / And now I must the chyld goo kyll. / Lord God, my conseons ys stron[g]ly steryd, / And yyt, my dere Lord, I am sore aferd / To groch ony thyng ayens yowre wyll."

${ }^{289}$ Coldewey, ed., Early English Drama Lines 121, 127, 164: "Thys chyldys wordys all towond my hart"; "A! Lord, my hart breketh on tweyn"; "My hart is now soo full of wo." Abraham repeats that his heart is pained in lines 299, 302, and 311.

${ }^{290}$ Coldewey, ed., Early English Drama Lines: 158-159: "Now trewly, sumwat, fader, ye thynke/ That ye morne thus more and more."
} 
shocked by the revelation, Isaac assures Abraham that he must toss aside his grief and fulfill the command: "I beg you father, do not mourn for me, / I shall soon be out of your mind / Therefore, do our Lord's bidding, / And when I am dead, pray for me." ${ }^{291}$ While Abraham is inspired by his son's selflessness and commitment to God, he still continues to mourn. Isaac is touched by his father's grief, but once again implores him to honor God: "O, mercy, father, mourn me no more. / Your weeping is making my heart sore." 292 Abraham expresses his struggle to kill Isaac either through descriptions of his love for him or through grand gestures of emotion. Abraham grieves throughout, even when Isaac accepts his fate. In regards to his father's grief, Isaac appears much more comforting and understanding than the maiden in the Pearl dream vision. In fact, he even grieves when he witnesses his father's sadness. Yet, ultimately, he takes a firm stance about emotional attachments vs. faith. Similar, but perhaps more understanding than the maiden, he tells his father that he must put aside his grief, making his spiritual life a priority over his children, and more generally, family.

The attitude towards male grief in the plays and the Pearl, falls in line with how grief is presented in some of the miracle stories involving excessive fatherly mourning (i.e., Jordan and Alan of Burton). In the Pearl, the maiden chastises her father for grieving so heavily, accusing him of not assuming his role of devout follower. This is similar to the miracle authors who show Jordan and Alan of Burton acting "womanly,"

${ }^{291}$ Coldewey, ed., Early English Drama Lines 200-204: “I prey yow, fader, make ye no wo0, / For be I onye ded and fro yow goo, / I schall be sone owt of yowre mynd. / Therfor doo owre Lordys byddyng, / And wan I am ded, prey for me."

${ }^{292}$ Coldewey, ed., Early English Drama Lines 283-284: “A, mercy, fader, morne ye no more. / Yowr wepyng make my hart sore." 
and stepping outside their roles of paterfamilias. All of the men cross boundaries that they should not, and their relatives either scold them or treat them with indifference to show their distaste for their behavior. Moreover, despite Abraham not being portrayed in a wholly negative light for his expressions of grief, he is still dissuaded from grieving so strongly so that he can fulfill God's command. Perhaps even more importantly, by grieving excessively Abraham shows to the audience that he is willing to continually sin against God, which Isaac recognizes and tries to reverse.

\section{CONCLUSION}

Authors of medieval miracles portray paternal grief in a variety of ways. Some choose to use the same rhetoric applied to mothers in mourning, whereas others apply different emotional expressions to grieving fathers. Although paternal grief could be public, it did not stem from the guilt of not protecting their children from harm and was often depicted as being more restrained than the public grief of mothers. This more restrained form of grief allowed fathers to focus on religion. When fathers did grieve excessively, narrators had a tendency to criticize them, depicting them as losing sight of religious devotion and the role of paterfamilias. Although the father in the Pearl and Abraham are not called "womanly," they are also reprimanded for their immoderate grief. Both fathers are controlled by their emotions and are told by their children that they are acting inappropriately.

Just as we saw in Chapter Two, the sources examined in this chapter would have acted as a medium to advise men about proper parenting and gender-appropriate responses to death. When hearing about miracles and poetry involving fathers and children, or watching a play about Abraham's sacrifice, men would have learned about 
the expectation for the paterfamilias to stay strong in the face of child death by curbing excessive sadness. Furthermore, they would have absorbed the idea that, while they should cherish their children and attempt to protect them in times of emotional trauma, grief over child death should not be a priority over one's faith. The next chapter will explore community responses to child death, specifically how neighbors and crowds at death scenes responded to dying children, and how they interacted with grieving families. 


\section{Chapter 4}

"Neighbors Ran to the Sound of Their Strange Cries": Community Responses to Child Death

"On the last day of August in 1481, Richard Queston took his four-year-old grandson, for whom he had a great affection (nimio in eum ferebatur affectu), to the mill where he worked in Westwell, Kent. While Richard was busy conducting business, the boy wandered off to play as he had normally done and by accident, fell into the trough between the wheel and millstream. Although the wheel was not moving on this particular day, the millrace pinned the boy down to the trough which was quickly filling with water. His grandfather, covered in tears (totus in fletum), rushed to find help, but neither he nor neighboring farmers (vicina rura colentes) were able to reach the child in time to save his life. The inconsolable crowd (luctus inconsolabilis) that had gathered at the scene, called out prayers in one voice (una vociferant) to Henry VI. Driven by grace rather than skill, one of the neighbors was able to reach the boy and carry him back to land, where the crowd sighed (suspiria) at the sight of the child's unmoving body. Prayers continued and the four-year-old was eventually restored to a state of perfect health, as though the accident had never happened in the first place. ${ }^{293}$

The anonymous author of the miracle story about the miller and his grandchild paints a poignant picture of the efforts taken by a medieval community to rescue a child when an ordinary day at the Westwell mill turned into tragedy because of an infortunia. The Westwell story not only provides an example of a typical child accident in the

${ }^{293}$ Grosjean, ed., Henrici VI, 17-19. 
Middle Ages, but also includes information about the anonymous narrator's expectations about community responses to child death and grieving families. Compilers of miracles regularly included descriptions of community reactions, alongside parental, to deaths of children in their works. As we saw in the previous chapters, authors of miracle stories showed fathers and mothers expressing grief in response to child death in a variety of ways: through prayer, vows of religious devotion, tears, sighs, and episodes of madness. Some accounts are brief, with narrators only noting that parents felt sadness over the loss of their children, while others offer much more detail, creating a vivid image of the strain of parental mourning. In the descriptions that contain more detail, there is often a clear gender divide in regard to expressions of grief. Religious authors, for the most part, portray maternal grief as public and indicative of the guilt that mothers felt for not supervising children, whereas paternal grief could also be outwardly expressed, but did not carry connotations of blame for child death or attract communities to child death scenes. Immoderate fatherly sadness could be viewed as a distraction from the role of paterfamilias and dedication to one's faith.

This chapter focuses on accounts of communities like that of Westwell. In this chapter, I argue two main points about depictions of medieval communities in child death accounts. First, I argue that authors of miracle stories regularly depicted communities as playing active roles in child death stories. Although emotion is not always present in every miracle account, as will be seen in the Simon de Montfort miracles, authors still expected communities to provide counsel to families who had experienced child death. Relatives of deceased children, too, were supposed to be able to turn to fellow community members for help during times of distress. Second, I argue that the authors of 
the Thomas Becket, Thomas of Cantilupe, Wulfstan, and Henry VI miracle collections portrayed community members as assuming roles of guardianship over children in dangerous situations. That is to say, authors expected medieval communities to work together to protect children from harm, and in this case, death. Community members often stepped up to protect children when parents or relatives were absent or unable to help children because of their overwhelming grief. Familial grief or the grief of someone close to a child, which manifested in shouts and tears, acted as a cue for members of a community to gather at, or run to, the scene of child death and help those in need. Not only did communities respond quickly to cries of distress, but parents and relatives of children knew that they could rely on fellow community members in times of need, since they are regularly depicted as calling upon neighbors (ềvocāre vīcinnus), or turning to neighbors, for aid. When tragedy struck, people attempted to resuscitate children and alleviate community and familial grief through physical means, such as by draining water from children's mouths if they fell into water. If physical resuscitation did not work, communities turned to their faith, performing religious acts, such as bending a coin or invoking a saint in exchange for a child's miraculous recovery. The idea of working in unity is underscored in miracle narratives, specifically the miracles of Wulfstan and Henry VI. For example, the author(s) of the Henry VI miracle collection actively used language that denoted the idea of "unity" when communities experienced child death, such as stating that communities used one voice (una vociferant) or one manner (uniuersi modo) to ask for divine aid in exchange for a child's recovery. Other writers, such as those writing about miracles attributed to Thomas Becket and Thomas of Cantilupe, commented that community members worked or prayed together to save children in order 
to create an image of solidarity within their miracle stories. Only a handful of miracles within these collections break away from this model. Some writers depicted individual community members as taking action to save deceased children and inspiring others to help in the revival process. If medieval people were unable to rescue children from death or felt helpless in terms of reviving a child, they still formed a network, but this time to participate in the mourning process with relatives and caretakers of children. This can be seen in the anecdote in the introduction to the chapter, where the crowd at the Westwell mill is grouped together while mourning the grandson's death. The crowd, together, is inconsolable and sigh when they view his lifeless body on the ground. Unable to revive him in that moment, the group grieves the loss together with the miller. Because the last two chapters focus heavily on gendered forms of grieving, it is important to note here that the emotion of grief, whether it be public lamentation, or more reticent grief in the form of sighs or prayers, is usually applied to a group as a whole. Therefore, while miracle writers applied some of the same emotional language and imagery to communities, seen in the previous chapters, distinctions between who is doing the grieving (i.e., male vs. female community members), is not usually made.

Medieval communities were comprised of various types of people with differing occupations and roles in society. There would be people with the job titles of miller, blacksmith, farmer, weaver, coroner, parish priest, tavern keeper, brewer, knight, sheriff (to name only a few). People within a community could be further categorized into their familial roles (e.g., brother, sister, nephew, etc.). For the purposes of narrowing down this project, the discussion in this chapter will be centered around the broader categories of "neighbors" "bystanders,"/“those gathered at a death scene," and "workers in a 
household" in miracle stories. The neighbor category makes the most frequent appearance, whereas only one account talks about servants in a household.

\section{CHILDREN IN MEDIEVAL COMMUNITIES}

Before evaluating miracle accounts of community, a brief discussion of the value of children within communities is necessary. Although the idea that medieval people lived huddled together in crowded living spaces is a myth, residents of medieval communities would have had constant contact and formed emotional bonds with one another on a daily basis. While discussing interactions between peasant families of fourteenth- and fifteenth-century England, Hanawalt explains that "villagers knew everything about their neighbors and for good or ill became involved with them."294 The communal nature of rural and city life brought individuals together. Community members would have interacted with children and their families when gathering water at communal wells, while ploughing fields together, socializing at taverns, borrowing goods from one another, attending mass or religious festivals, conducting business, and performing legal duties. In cities, too, people would have made connections with each other while trading, going to market, and passing guild workshops on the streets. City life, no matter how big, also had a communal element. People talked at communal wells, borrowed work tools from each other, and worshipped together. Thus, people were invested in the lives (and deaths) of their fellow neighbors, especially the lives of children. Children were not viewed as social "others" until they reached an age of survival as was once argued in

${ }^{294}$ Hanawalt, The Ties that Bound, 29. 
1960s/70s scholarship, but rather, children of all ages were a vital part of the immediate family, and also the wider community. By this, I do not mean that children were considered important just because of their potential contributions to the medieval economy. The communal nature of villages and cities fostered an environment where children were valued. Children were cherished and assumed their own identities within the communities in which they lived.

These ideas are proven in acts of charity towards children. Herlihy viewed the medieval family as an isolated entity in which the head of household was at the top of the hierarchy, keeping the household harmoniously functioning. Hanawalt, on the other hand, argued that, although the nuclear family worked together to ensure the success of the household, relied heavily on layers of support from the community, both during times of crisis and for everyday matters. This especially holds true for children needing community aid. Although churches and hospitals were expected to provide charity to homeless children, community members often helped destitute children, by taking in orphans or providing money for child funerals when parents could not afford to do so. ${ }^{295}$ The importance of children to medieval society is also evidenced in rites of passage ceremonies surrounding birth. The ritual of baptism in particular "was the beginning of

\footnotetext{
${ }^{295}$ Roy Hunnisett, trans., Bedfordshire Coroners' Rolls, Bedfordshire Historical Record Society 41 (Streatly: Bedfordshire Historical Record Society Publications, 1961), 39-40. The rolls show that neighbors helped abandoned children. When Roger, age eight, was outside the house of Reynold le Wyt crying because he did not have a home, Reynold came out to console the child, but was killed by robbers. See also Hanawalt, The Ties That Bound, 252. Hanawalt says that some coroners' inquests show evidence of villagers taking in orphaned children. While the adoption of children was not done in a formal sense, with the signing of formal agreements that we see today, parentless children were taken in by community members, as evidenced in wills, especially members of a community that did not have any children of their own.
} 
the development of an individual's social network." ${ }^{296}$ Baptism gave a child its own identity within a community, and established relationships between a child and its godparents, parents, fellow community members, and local parish. ${ }^{297}$ Orme explains that the protocol for later medieval baptisms was outlined in a Latin service book called the Manual, which clergy carried as they performed the ceremony. ${ }^{298}$ The first part of the ceremony involved newborns being exorcised of Original Sin outside of the parish church, because they were not yet Christian, and therefore not yet "fit to enter the church." ${ }^{299}$ Accompanying the infant were parents, godparents, and the midwife (or midwives), who attended the birth. ${ }^{300}$ Next, the infant would be carried inside the church to the baptismal font. The priest, after asking the infant questions about renouncing Satan,

\footnotetext{
${ }^{296}$ Hanawalt, Growing Up in Medieval London, 46.

${ }^{297}$ Orme, Medieval Children, 35; Gilchrist, Medieval Life, 185; Hanawalt, Growing Up in Medieval London, 46.
}

${ }^{298}$ Orme, Medieval Children, 27. Orme discusses the procedure outside of the church further. Midwives were asked whether the child was male or female. If male, it was placed to the right of the priest, symbolizing strength and dominance. The priest would then perform several other rituals, such as making the sign of the cross over the newborn's head, asking for the child's name as he placed his hand on their head, and an exorcism involving putting salt into the mouth of the infant. He would finish off the outside part of the baptismal ceremony by moistening the infant's ears and nostrils with saliva (as Jesus did to cure deaf and mute man in Mark 7:31-37), making the sign of the cross over the infant's right hand, and then permitting the infant to enter the church. For more information on the Manual, see Jefferies Collin, ed., Manuale ad Vsum Percelebris Ecclesie Sarisburiensis, Henry Bradshaw Society 91 (Chicester: Moore \& Tillyer, 1990).

${ }^{299}$ Orme, Medieval Children, 27-28.

${ }^{300}$ Gilchrist, Medieval Life,185; Orme, Medieval Children, 27-8; David Cressy, Birth, Marriage and Death: Ritual, Religion, and the Life-Cycle in Tudor and Stuart England (Oxford: Oxford University Press, 1997), 135. 
which the godparents answered for the child, put the newborn into the baptismal font. ${ }^{301}$ The name of the child was also formally announced aloud for the first time after birth in front of everyone during the ceremony. This official pronouncement made at the time of baptism marked not only the entrance of a newborn into "the Christian community," but also into the society into which it was born. Naming a child before or during baptism in and of itself supports the idea that medieval children were valued in medieval societies. Names held power and solidified one's identity. To borrow a phrase from Orme, "Our names are our earliest possessions." ${ }^{302}$ Names give information about one's family, community, status, social ties, and religious devotion. Children were named after saints favored by a family or community, thus linking them to a specific household or community, or after saints associated with a particular social class ${ }^{303}$ Children were also affectionately named after recently deceased relatives, highlighting the fact that children (and family ties) were important. They could also be named after godparents. By the later Middle Ages, the practice of naming a child after their godparent was common. Orme explains that medieval people believed that godparents might do more for the child if they shared their names. This led to several children of the same family having the same name ${ }^{304}$ On the other hand, Scott Bannister argues that children were named after their

\footnotetext{
${ }^{301}$ Shulamith, Childhood in the Middle Ages, 46. Shulamith writes that sometimes the infant undergoing baptism was fully submerged in the baptismal font, lest the infant was not fully baptized otherwise. See also Orme, Medieval Children, 28-29.

${ }^{302}$ Orme, Medieval Children, 36.

${ }^{303}$ Steve Boardman and Eila Williamson, eds., The Cult of Saints and the Virgin Mary in Medieval Scotland (Woodbridge: The Boydell Press, 2010), 185.

${ }^{304}$ Orme, Medieval Children, 37; See also Paul Newman, Growing Up in the Middle Ages (London: McFarland \& Company, INC., 2007), 32.
} 
godparents because they were supposed to be their protectors, both from spiritual and earthly harm. ${ }^{305}$ Godparents not only played a significant role in helping children enter into a spiritual community at the time of baptism, but were also supposed to teach children about the faith and make sure they lived past the fragile stages of childhood. ${ }^{306}$

The value of children to communities can also be seen in their portrayal on family brasses. Brass engravings became popular in England around 1270 and London dominated the brass-making business, until around 1440 when brass-making centers popped up in Norwich, Durham, Cambridge, Bury St. Edmunds, and Coventry. ${ }^{307}$ Lowstatus brasses, called minor funerary brassed, contained cross-slabs, whereas monumental brasses with images of people (including children) on them would have been commissioned by wealthier families. ${ }^{308}$ John Page-Phillips states that children on family brasses were depicted as weepers, usually placed at the foot of their parents image or to their sides. ${ }^{309}$

\section{COMMUNITIES IN CHILD DEATH ACCOUNTS}

\footnotetext{
305 Scott Bannister, Names and Naming Patterns in England 1538-1700 (Oxford: Clarendon Press, 1997), 27

306 Shulamith, Childhood in the Middle Ages, 117.

${ }^{307}$ Sally Badham, "Evidence for the Minor Funerary Monument Industry 1100-1500," in Town and Country in the Middle Ages: Contrasts, Contacts, and Interconnections, 11001500, eds. Christopher Dyer and Kate Giles (Leeds: Maney Publishing, 2006), 165, 170.

${ }^{308}$ Badham, "Evidence for the Minor Funerary Monument Industry," 166; See also Orme, Medieval Children, 121.

309 John Page-Phillips, Children on Brasses (London: George Allen and Unwin LTD, 1970), 14.
} 
The themes of calling upon community members for help, turning to neighbors in times of sadness, and residents of a village hearing the cries of distraught parents is common in most miracle stories of the high- and late- Middle Ages in England. Some accounts, like those found in the Simon de Montfort miracle collection are brief, and do not contain elaborate emotional dialogue, but do mention communities being part of the child death scene. Monks at Evesham are credited with compiling the miracles of Simon de Montfort, who led the rebellion against Henry III. Although nearly two-hundred miracles are associated with Simon de Montfort, he was never officially recognized as a saint. ${ }^{310}$ The Simon de Montfort collection is a curious one because it reads like a set of coroners' inquests, with only cursory descriptions of child accidents/illnesses, information about how children were miraculously cured by Simon de Montfort, and lists of witnesses at the end of each passage. This structure is much different from the other miracle collections in this study, which typically do not include a list of witnesses, or any witness names, in some cases. Gordon suggests that the reason the miracles are structured in this way is because the monks at Evesham did not want Simon de Montfort to be considered a saint, but still felt obligated to record his miraculous deeds. These miracles were written after the monks of Evesham buried his dismembered body following the Battle of Evesham. ${ }^{311}$ Robert Bartlett agrees with Gordon that pressure was made to prohibit Simon de Montfort from becoming a saint because he was a rebel to the English

\footnotetext{
${ }^{310}$ For more information on Simon de Montfort's life see John Maddicott's Simon de Montfort (Cambridge: Cambridge University Press, 1994).

${ }^{311}$ Gordon, in “Accidents Among Medieval Children," 147-148.
} 
government. Despite attempts by royalty to destroy any links between him and sanctity, people still reported miracles attributed to him. ${ }^{312}$

Within the collection, whole villages or neighborhoods are often cited as testifying as witnesses to divine intervention in order to emphasize the credibility of the miracle, but details about the actual interactions between community members and families of deceased children are sparse. ${ }^{313}$ Out of the fourteen miracles stories involving deceased children in this collection, eight contain notations of community involvement within the child death story, and within these notations, emotional characteristics are not applied to parents or other community members. ${ }^{314}$ Most of the accounts reference parents seeking the advice of neighbors when a child dies (four miracles), or neighbors confirming the death of a child (four miracles). One example of neighbors confirming the death of a child is found in a miracle about a girl from Lincolnshire. When the neighbors judged the girl to be dead (omnibus vicinis judicatam), she was measured to Simon de Montfort ${ }^{315}$ Four miracles recount parents reaching out to community members for

312 Robert Bartlett, Why Can the Dead Do Such Great Things?: Saints and Worshippers from the Martyrs to the Reformation (Princeton: Princeton University Press, 2013), 181.

${ }^{313}$ An example of a whole village testifying to a miracle can be found on page 74 of Halliwell, ed., The Miracles of Simon de Montfort. In a miracle where a boy fell into a drain and drowned, the whole community (tota villata) of Besseborne witnessed his recovery once he was measured to Simon de Montfort. Villata can also translate to "township."

${ }^{314}$ Halliwell, ed., The Miracles of Simon de Montfort, 105. The only other miracle in the collection that does describe emotion (but does not talk about community), is noted in the previous chapter. It is about a boy named Johannes, who fell into a rushing stream and died (cecidet in torrentem et submersus mortuus est). According to the author, his father, Philippy sighed and shed tears (gemens et lacrimans) about the loss of his son.

${ }^{315}$ Halliwell, ed., The Miracles of Simon de Montfort, 98. 
advice on how to revive their children. In one, William Gullafre de Havekebore and his wife sought the counsel of neighbors (consilio vicinorum) when their son, Henry, died from a grave illness. The neighbors and his parents measured (mensuraverunt) him to Simon de Montfort and he was subsequently revived. ${ }^{316}$ In a second account, Jacobi de Fancote was advised by bystanders, or certain people gathered at the death scene (consilio quorumdam) to measure his son, who had drowned in a fountain. ${ }^{317}$ A miracle with a bit more detail about community members is about a birthing scene. When a woman suffers from dropsy (hdropisi) during labor, her child is born dead (abortivum). The midwives at the scene pray and suggest that Simon de Montfort be called upon for help. ${ }^{318}$ Despite the fact that these miracles do not contain emotional dialogue, they can still offer insight into expectations about medieval communities. The author(s) expected community members to be present for children and their relatives, for relatives of

${ }^{316}$ Halliwell, ed., The Miracles of Simon de Montfort, 77-78.

${ }^{317}$ Halliwell, ed., The Miracles of Simon de Montfort, 77.

${ }^{318}$ Halliwell, ed., The Miracles of Simon de Montfort, 84. A miracle that resembles this one can be found in the Thomas Becket collection, Materials for the History of Thomas Becket, 222-223. Benedict of Peterborough reports that Aliza of Middleton was pregnant and suffered from dropsy (hydropis), a disease characterized by watery fluid in the body that causes the swelling of the limbs. During labor, she was given medicine (medicinas terrenas), but nothing made her feel better. She decided to ask for help from celestial doctors (medicos coelestes), such as Saints' Edmund, Leonard, and Margaret, but they were not able to help. Desperate, she asked that her uterus be cut open so that the child, which she thought might be near death at that point, be baptized (uterum sibi rogabat aperiri, infantem extrahi; ut quamvis non natus, renatus tamen fonte salutary, vel viveret vel morertur Domino). When everyone refused to do this, the seven midwives (obstetrices septem) advised the woman to seek the help of Thomas Becket. Once the woman vowed to visit the martyr's shrine, water began to flow from her womb and a healthy boy was born. Although this account, like the one attributed the Simon de Montfort, lacks emotional dialogue concerning grief, the imagery of a desperate mother, who is willing to cut open her uterus to save her child, implies that the midwives responded to her grief. 
deceased children to be able to turn to neighbors for help when they could not revive their children, or when a death needed to be confirmed (possibly to report the death to a coroner).

\section{GRIEF AND COMMUNITY UNITY IN CHILD DEATH ACCOUNTS}

In contrast to Simon de Montfort miracles, the emotion of grief in accounts involving communities is more widespread in the Thomas Becket, Wulfstan, Thomas of Cantilupe, and Henry VI collections. Sometimes authors solely applied grief to parents of children who interacted with community members, while at other times authors portrayed community members as participating in the mourning process, alongside parents or relatives. A couple of examples in which communities are mentioned, but where grief is applied only to parents are as follows: In a Thomas Becket miracle, a child named Gilbert Sarre drowned after being left unattended in a bath for three hours. Once his mother found him she cried and shrieked (Clamante et eiulante), so that all the women of the neighborhood came running (accurrunt mulieres vicince). They immediately suspended Gilbert by his feet (Suspendunt pedibus infantem), but he did not show signs of life. One older woman did not believe the child could be recovered, but another woman said that everyone must kneel and invoke Thomas Becket (genibus beatum Thomam martyrem invocemus). When this did not work, they got a string to measure the boy (metire) for the saint and he was finally returned to the physical realm. ${ }^{319}$ In another miracle, this one attributed to Wulfstan, the three-year-old son of Hugh and Emma appeared dead after suffering from an illness (the cause and type of illness are not noted). Emma and Hugh

${ }^{319}$ Benedict of Peterborough, Materials for the History of Thomas Becket Vol. 2, 228. 
were grief-stricken and neighbors ran to the sound of their strange cries (accurrunt vicini ad insolita lamenta) ${ }^{320}$ In both examples, neighbors respond quickly to parental grief. The cries of Gilbert's mother alert neighbors to the fact that she needs help and they quickly take action. In the case of Hugh and Emma, neighbors rush to the family's home in order to determine the cause of the commotion.

Accounts of child death which contain community participation in the mourning process are also present in the miracle collections mentioned above. Within these accounts, authors highlight the idea of community "unity," whether it be unity in grief for a deceased child or unity in attempting to resuscitate a child in order to alleviate grief. Community members are described either as being part of a crowd or as specific individuals taking action and inspiring crowds to help children and grieving parents during times of turmoil. An example of the former description is showcased in the Henry VI miracle story about Joan, the daughter of Richard Walran from Berkshire, who died when she accidently hung herself from leather straps on a cellar door. The anonymous narrator explains that Joan, mischievous and young, got her head stuck in leather straps tied to a door in her home. He goes on to say that, the devil, who not only rejoices in the destruction of our bodies, but also our souls (qui non corporum solummodo sed animarum pocius gaudet interitu), made the door fall, causing the leather straps to act as a noose and kill the girl. ${ }^{321}$ Joan's mother, who had been away from the home conducting business, found her hanging from the straps and immediately called upon her neighbors (evocat vicinos) for help. A crowd gathered (multitudo) at the scene and began lamenting

${ }^{320}$ Darlington, ed., Vita Wulfstani, 163.

${ }^{321}$ Grosjean, ed., Henrici VI, 141. 
in unison at the sight of the mother's misery (plangent universi metissime matris miseriam) ${ }^{322}$ Grieving in unison is also expressed in a miracle associated with Wulfstan. The author of the miracle recounts a woman lamenting the loss of her son. The mother cried out and sighed loudly (Mater clamore valido ingemuit) and the villagers approached and shed tears together (populumque collacrimari coegit). ${ }^{323}$

The concept of being in unison is repeated in the narrative about Joan, who was hanged on the door. After the crowd grieved together, they soon become miraculously united in one mind (mox universi modo miro in unam conuenere) to ask Henry VI for help..$^{324}$ The reactions of the neighbors to Joan's death bear a striking resemblance to those of the neighbors in the story about Richard Queston and his grandson, also from the Henry VI collection. The miracle writer(s) depict(s) both sets of neighbors as invoking Henry VI's healing powers in unison in order to alleviate familial grief and save children, rather than describing them as individual vicinae within a larger community. In the Richard Queston miracle, once the neighboring farmers and the crowd of onlookers at the mill witness the death scene and the grandfather's sadness, they are compelled, through divine inspiration, to use one voice, representing one community, to pray to Henry VI. Similarly, in Joan's miracle, the neighbors are motivated to pray to Henry VI because the thought enters their minds simultaneously, after they observe the mother's helplessness over the loss of her child.

\footnotetext{
${ }^{322}$ Grosjean, ed., Henrici VI, 141.

${ }^{323}$ Darlington, ed., Vita Wulfstani, 121.

${ }^{324}$ Grosjean, ed., Henrici VI, 142.
} 
Communities acting with "one mind" is found in another miracle story, this time taking place in Rye, Sussex. The daughter of John Denys, Margaret, who was seven years old at the time, went outside to play in her neighbor's garden, without parental supervision (lusitandi licencia). The narrator explains that, somehow, perhaps by the force of an evil spirit (sed iniquo forsan spiritu impellente), Margaret sunk into the garden fish pond and drowned ${ }^{325}$ Margaret's parents searched for her for about an hour, asking neighbors about her whereabouts, but failed to find her. Fear and heavyheartedness fell upon all of them (tunc timor et hebetudo mentis cecidit super omnes). ${ }^{326}$ Eventually, the owner of the pond found the child floating in the water and pulled her out with a cord. The neighbors, moved (at the same time) by their pity for Margaret and compassion for her grieving parents, knelt on the ground with them and cried to the heavens. ${ }^{327}$ Henry VI, along with the holy mother [The Virgin Mary], heard the mourners' supplications and revived the child ${ }^{328}$ Similar to the miracles about Joan and the miller's grandson, the community in Rye comes together to play an active role in the child-resuscitation- and mourning-process. Once the neighbors are alerted to a crisis, they

\footnotetext{
${ }^{325}$ Grosjean, ed., Henrici VI, 177. The fact that the author juxtaposes the ideas of Margaret being left unsupervised and the devil being responsible for her death, might serve as a warning to parents that children should not be left unattended, because of dangers hiding around every corner.

${ }^{326}$ Grosjean, ed., Henrici VI, 177. The term hebetubo translates to "bluntness" or "sluggish," but in this context, refers to a "heavy" feeling of grief amongst the community.

${ }^{327}$ Grosjean, Henrici VI, 177: "Verumptamen hij qui conuenerant uniuersi moti tandem tum pietatis titulo in puellam, tum parentum gemitibus condolentes: una cum eisdem flexis in terram genibus clamorem validum extulerunt ad sidera."

${ }^{328}$ Grosjean, Henrici VI, 177.
} 
take action as a group to help the parents find their missing child. Once Margaret is found dead, they mourn in unison with the parents and plead, as a group, with Henry VI to restore her life. What is different about this account in comparison to the others, is that the narrator provides far more emotional language about the community than is seen in other miracles. Thus far, narrators have only mentioned grief in general terms, stating that the communities lament together or are inconsolable in response to child death. In this story, the miracle writer gives a more in-depth look at emotional responses to child death. Even before Margaret is known to be dead, her community experiences a sense of dread when she is nowhere to be found. According to the narrator, "heaviness" (hebetudo) weighs them down. The neighbors are also filled with fear (timor), an emotion not directly named in any of the previous stories, including those about parental grief. Furthermore, the author takes the time to add that the community's mourning stems from the sadness they feel for both Margaret and her distraught parents.

Authors of miracles also depict community unity without using terms such as "unison." One author writes about two-year-old Benedicta, who meets a tragic fate in her home in Cranbrook, Kent. Left unsupervised, Benedicta fell onto a knife which pierced her throat nearly three inches deep (ipso ferro ad mensuram fere digitorum trium in eius gurgulione transfixo). Like in the stories of Joan and Margaret, the author suggests that the devil, who is a murderer (homicidium), might be responsible for such an accident. ${ }^{329}$ The author of the miracle goes on to say that the neighbors that appear at the death scene grieve just as much as Benedicta's parents (Unde etsi parentibus ipsis premaxime, plurimum quoque adventantibus illis vicinis mesticie). The neighbors then promised

\footnotetext{
${ }^{329}$ Knox and Leslie, eds. and trans., The Miracles of King Henry VI , 63.
} 
Henry VI large gifts of their devotion (munera devocionis intime non pauca promittere), if he revived the girl. ${ }^{330}$ Unlike the other miracles, the author does not apply the quality of "oneness" to Benedicta's neighbors, but the quality is instead implied when he describes the crowd of neighbors praying together with her parents. In other words, the narrator still creates an image of the neighbors working together to achieve the same goal (i.e., divine intervention) even though they are not described as praying with one voice or one mind. ${ }^{331}$

\section{INDIVIDUALS INSPIRING COMMUNITY UNITY IN CHILD DEATH}

\section{ACCOUNTS}

Authors of miracle stories also displayed the heroic and holy actions of individual community members in child death accounts. In one Henry VI miracle, for instance, a one-year-old Anne, the daughter of Thomas Plott from Sheppey, was crushed by a loaded wagon while she was wandering around a public road on the Eve of Corpus Christi. A cart driver, in service of nuns at the local convent, flattened her body like a pancake (quassatum in modum fere placente planum) because he drove without caution or care (ast illo incauto satis que negligenter agente). ${ }^{332}$ The narrator creates a somber setting for

${ }^{330}$ Knox and Leslie, eds. and trans., The Miracles of King Henry VI, 64.

${ }^{331}$ There are also cases where communities grieve together with families, but may not offer solutions to child death. For instance, in a Wulfstan miracle, an infant appears dead after nursing. The mother summons her neighbors (vicinos convocante). The neighbors stand by lamenting and crying (dolentes et flentes). Once they judged the infant to be dead, those standing by the mother were saddened (astantibus mulieruli contristanti). The mother later called upon Wulfstan and the child was revived. See Darlington, ed., Vita Wulfstani, 178.

${ }^{332}$ Grosjean, ed., Henrici VI, 200. 
the neighborhood, reporting that certain neighbors found out what happened and soon ran up to the scene of the accident, bewailing the shocking crime with shrieks (Id que mox comperiunt viciniores quidam accurentes: atque eiulatu non infaustum facinus lamentantes). ${ }^{333}$ Filled with anger and grief, Anne's mother followed the driver to yell at him about the crime against her daughter, while one neighbor, Agnes Andrew, whose faith in Christ was strong, grabbed a penny from her purse (rapta a bursa denarium) and bent it over Anne's corpse to invoke divine intervention from Henry VI. The author explains that Agnes's act motivated the rest of the crowd to imitate her holiness, and they began repeating the same prayer and request. Soon, Anne was returned to the physical realm unscathed ${ }^{334}$ Here, one neighbor stands out from the rest of the crowd and motivates the group to pray as a single unit. Thus, while the community still works together in the end, Agnes inspires the crowd to be united in their faith. It is also important to note that the contrast between "good" and "bad" community members is made between the cart driver, Agnes, and the rest of the community. The author lauds Agnes's actions, stating that her heart and faith is deeply rooted in Christ (Interea autem femina quedam animosa fide in Christo fundata), since she tries her best to revive the child through holy means, whereas he applies negative characteristics to the cart driver from the start of the story because he does not perform his job correctly, does not show remorse for his actions, and does not join the community in pleading for divine aid. ${ }^{335} \mathrm{He}$ explains that the cart driver is negligent in his job and emphasizes the gravity of the

\footnotetext{
${ }^{333}$ Grosjean, ed., Henrici VI, 200.

${ }^{334}$ Grosjean, ed., Henrici VI, 201-202.

${ }^{335}$ Grosjean, ed., Henrici VI, 201.
} 
situation with gruesome imagery, such as noting that the little girl (puellulam) is flattened by the entire weight of the cart (totum pondus vehiculi) because of his lack of caution. ${ }^{336}$ Furthermore, the author alludes to the fact that the driver does not stay to help like the other community members, since Anne's mother must follow him after the accident takes place.

In another miracle from the same collection, an Abbess inspires community to seek divine intervention after an infortunia. A boy named Thomas Scott, in the company of the Abbess of Burnham, travels to Windsor Castle. In an instance of childish behavior (insolencia puerili), the boy climbed a tree and when he was about thirty feet from the ground, he fell down head-first. The news of his probable death upset the entire household, with the male servants shouting and running back and forth (mox universa turbatur familia. Fit undique clamor discursus que vlulantium famulorm). Soon, the whole community had congregated at the scene and attempted to revive the boy by rubbing his forehead, temples, and hands, and poking his chest for signs of life or death (Tota deinde congregator comitiua monialium. Palpat una frontem alteram anus illa pectus pungit cetere tempora confricando explorant undique vite vel mortis indicia). Two hours passed when the Abbess finally joined the crowd, almost fainting because of her abundant grief (abundantiori tristicia). She began praying to Henry VI and her sisters, inspired by her faith, followed in unison (Imo et universe circumstantes sororcule concordi pietate perique deuocione illi votorum munia deuovendo). The author adds that

${ }^{336}$ Grosjean, ed., Henrici VI, 200. 
the boy was eventually restored to life, and the sorrow of everyone present was alleviated (merore alleviates omnium). ${ }^{337}$

In this story, the community surrounding Windsor Castle, a community that the boy is only visiting, is turned upside down when he falls from the tree and is seemingly dead. The authors portray servants as expressing their grief by running around frantically when they learn the child is dead. While the servants and the rest of the community make efforts to revive the child before the Abbess arrives, she is still placed in the foreground of the story because, like Agnes in the miracle from Sheppey, she seeks help through a religious method. It is she who inspires her fellow nuns to surrender to the will of Henry VI in the form of prayer, which is the reason the boy is resuscitated at the end of the story. While the secular community came together to revive the boy through physical means (rubbing his temple, poking at his body), it is the person of faith that comes through, and inspires others with her religious vigor. The narrator even notes that once the boy is brought back to life, the Abbess ventures to Henry VI's shrine as a token of her gratitude, reinforcing the idea that she follows correct religious protocol. ${ }^{338}$ Here, it is significant to point out that the Abbess's method of revival is probably showcased to validate the narrator's overall agenda: to prove Henry VI is deserving of canonization. Nevertheless, the author of excerpt also puts forth beliefs on community intervention, specifically the ideas the communities should attempt to help children in danger and turn to their faith in times of crisis. Furthermore, even though we only get a brief glimpse into the Abbess's emotional state of mind after the accident takes place, the author uses the

${ }^{337}$ Grosjean, ed., Henrici VI, 102-103.

${ }^{338}$ Grosjean, ed., Henrici VI, 102-103. 
adjective "abundantiori" to stress just how strongly she grieves for the child under her care. She, too, is part of the community and expresses her sorrow for the loss of a child under her care.

Male neighbors are also placed at the foreground of child death accounts. In a Henry VI miracle, a seven-year-old servant girl from Kent lost her footing and fell into a well like a lump of lead (velut plumbi massa) while drawing water for her mistress, Dame Margery Hacket. Margery started searching for the girl when she realized that she had been gone for almost an hour. When she saw the wooden bucket, which the girl had been using to collect water floating in the well, she realized that the girl had fallen. Margery quickly sought the help of her nimble and strong (strenuum et robustum) neighbor, Thomas Stokes, who, without delay (postposita mora), leapt into the well and was able to carry the girl's lifeless body out of the structure. A crowd gradually formed around the scene of the accident and Stokes publically vowed not to eat meat or fish (carnium aut piscium) until he visited Henry VI's shrine in exchange for the child's recovery. After an hour had passed without the girl regaining consciousness, Stokes continued to pray, while onlookers began to beat their chests with anguish (pangentibus) and pray in the background. The girl gradually began to move and eventually made a full recovery. ${ }^{339}$ Another water-related accident that highlights a specific neighbor is from the Thomas of Cantilupe miracle collection and occurred in September of 1305, this time to William of Donington, aged two, who attempted to follow his mother across a wooden bridge over the Somergeld stream. The bridge was uneven and not well maintained,

${ }^{339}$ Grosjean, ed., Henrici VI, 293-294. 
causing William to slip into the water and drown. Thomas of Donington, William's cousin, saw the boy's body floating in the water and raised the hue and cried. Hearing Thomas's cry for help, villagers rushed over and extracted the child from the water. The narrator comments that his body was stiff and cold (frigid sicuit lapis). William's mother, Alice, and father, John de Lorimer, were not at the scene, and the maid in charge of watching William fled from the house once she heard of William's drowning. One neighbor, Hugh of Atforton, who had regularly fished by the bridge and initially warned William's mother about its bad condition and the fact that William was trying to follow her, urged the weeping crowd to pray to Thomas of Cantilupe and measure the child to the saint. ${ }^{340}$ While prayers commenced, Hugh lifted William upside down to drain water from his mouth, stuck a piece of wood in his mouth to drain more water, and turned him on each of his sides in an attempt to warm his body. When the boy showed no signs of life, he carried the child's corpse to his parents' home ${ }^{341}$ Community intervention and compassion does not end here. The story takes an odd turn at this point. According to the narrator of the miracle, once Hugh's father learned of his son's death, while unable to bear the sadness (dolorem ferre nequiens), he still decided to keep his dinner plans at the house of Lord William of Burwor, leaving his son's corpse alone in their home. Hugh (and other villagers), stayed with the boy until he started showing signs of life (i.e.,

\footnotetext{
${ }^{340}$ Finucane, The Rescue of the Innocents, 236. Finucane states that Hugh of Atforton actually tried to warn William's mother, Alice, that the boy was trying to follow her over the bridge. Alice denies hearing this warning altogether. At the time of the accident she was traveling across the village to run errands, and her husband was attending church a mile away from the accident scene.

${ }^{341}$ Finucane, The Rescue of the Innocents, 106-107.
} 
groaning, biting down on his finger, moving his eyes, and finally regaining an appetite).$^{342}$

The examples presented above, including the story about the four-year-old boy provided in the introduction, show neighbors as having active roles in accounts of child death and grief. It was not uncommon for witnesses to be present after child deaths occurred because community members were required to go to the scene of an accident or a potential crime and "raise the hue and cry," as Thomas of Donington did when he saw his cousin floating in the Somergeld stream. Despite the fact that people were legally obligated to check on others in times of tragedy, the miracle stories of Wulfstan, Thomas of Cantilupe, Henry VI, and Thomas Becket demonstrate that religious men expected neighbors to go beyond their legal duties and act with compassion when children died or were injured. In other words, authors portrayed neighbors as fulfilling their legal obligations by checking on children in distress, but then as transcending these legal duties when they collectively expressed deep sorrow for the loss of children and attempted to resuscitate them.

Authors invariably employed the emotion of grief in order to stress this idea. In the stories about the girl from Kent and the boy at the mill in Westwell, the distress of the mistress whose servant-child falls into a well and the grandfather whose grandson slips into the trough alerts neighbors to the fact that an accident has taken place, that help is needed, and also prompts the community to grieve along with relatives. In fact, the neighbors in Kent beat their chests because their grief is so strong. In Sheppey and Donington, too, neighbors act quickly and grieve heavily when they learn of Anne and

${ }^{342}$ Finucane, The Rescue of the Innocents, 107. 
William's deaths. William's community attempts to resuscitate him when hearing his cousin's cries of distress, both by lifting him upside down and through prayer, while Anne's neighbors employ a purely spiritual approach to her recovery: prayer and the ritual of bending pennies over her body. In the miracle about Joan, parental grief also acts as motivation for neighbors to intervene after an incident of infortunia occurs. The neighbors in Joan's story witness her mother's despair, which brings on divine inspiration to pray to Henry VI as a singular unit. Furthermore, the author of the story about Margaret drowning in the fishpond in Rye directly points to the compassion the neighbors have for Margaret's parents once they realize she is missing (and eventually dead). Neighbors in this miracle are also weighed down by grief as the events unfold. The only example that does not quite fit this formula neatly is the miracle about Thomas Scott and the Abbess of Burham. The servants at Windsor Castle and the surrounding community members are not alerted about the boy's death with cues of grief, but find the boy on the lying on the ground after the accident occurs. This does not mean that grief is absent from the story or that it is not used as a factor in driving the Abbess and the rest of the community to help the boy through physical means and divine intervention.

It is also significant to mention that community members, in some miracle cases, help children when parents, relatives, or caretakers are absent when an accident takes place or are unable to help children themselves. William of Donington's mother was running errands and his father was at church when he fell into the stream, Richard Queston was conducting business at the mill, the mistress in Kent was doing housework when her servant fell into the well, the Abbess was not at the scene of the tree accident when Thomas Scott fell, and Margaret's parents were inside their home when she fell 
into her neighbor's fishpond. Because of a lack of supervision, community members stepped in and assumed the role of guardian over unsupervised children. Considering this evidence, it is clear that authors of miracles reinforced the idea that supervising and protecting children was important because they were valuable to the community, and put forth the messages that parents and relatives were not the only ones who had a responsibility to protect children. Neighbors needed to go out of their way to ensure that children would be safe and to make attempts to resuscitate them after an accidental death, especially when parents were not around, or incapable of helping because of their grief or inability to save a child from whatever danger was presented. An example of the latter point can be seen in the Westwell miracle, where Richard's grandfather is not able to reach his grandson in the trough. Or the miracle where Margery Hacket is unable to reach the body of her servant in the well.

A miracle story that drives home the idea that community members became guardians over children when parents or other relatives were not around takes place in the village of How Caple in Herefordshire. One Saturday morning, John the fisherman asked his eight-year-old son, Nicholas, to gather branches lying in a boat by the river to make hobbles for their cow. As Nicholas reached for the branches, the ground gave way and he fell into the river and drowned. Thinking that Nicholas was off engaging in youthful play (juvenili levitate), his parents were not concerned by his absence and it was not until later that day that witnesses informed them about the accident. Both parents ran to the river and found him floating in the water in his linen clothing (ut pauper). They were overcome by crippling emotion of the heart (commotis viscerbus) and collapsed. Seeing the boy's parents faint, two neighbors, Cristina and Felicia, pulled Nicholas out of the 
river, threw water onto the faces of his parents to wake them up, and then tried to resuscitate Nicholas by lifting him upside down. When Nicholas woke up, his mother measured him to Thomas of Cantilupe. ${ }^{343}$ Similar to the other miracles, neighbors see parental grief as their cue to revive a child on their own and by negotiating with saints through prayer. Unlike in the other stories, Nicholas's parents are physically incapable of helping him recover at first because their grief becomes so overwhelming that they can no longer stay conscious. Therefore, Cristina and Felicia step in to protect the child when they faint from grief. Community presence does not end after this part of the story. Members of the community also make an appearance after Nicholas's resuscitation. To celebrate his recovery, the entire village of How Caple goes to the cathedral where the miracle associated with his accident is retold and Nicholas is displayed in front of everyone. Ending with these details, the author of the story not only points out that the miracle was verified in front of witnesses, the whole community, but further stresses the idea that medieval people were invested in the lives of children because the residents of How Caple celebrated Nicholas's recovery as a community.

There are, of course, exceptions to the examples above. In a miracle attributed to Wulfstan, the author states that a wet nurse (nutrix) was bathing an infant and went outside to gather firewood so that the water might be heated. When she came back, she saw the little boy submersed in the water, with his head turned downwards (vidit paruulum aqua submersum, verso capite deorsum). Shouting (clamavit), she attracted the attention of neighbors (vicinos). While the neighbors tried to figure out what to do about

${ }^{343}$ Finucane, The Rescue of the Innocents, 111-113. 
the child, the wet nurse fled the scene (nutrix interim sibi fuga). Eventually, the remaining neighbors called upon a priest, who called upon Wulfstan for help and the child was revived. While this account does not directly paint the wet nurse in a negative light, the author takes the time to note the detail that she leaves the accident scene. This, coupled with her shouting, suggests that she worries only for herself (fearing that she will get in trouble for neglect), not the child. ${ }^{344}$ In another miracle, a girl named Joan is pushed into a pond by an alehouse by another child and drowns. Instead of mourning over the child or attempting to revive her, the onlookers first try to conceal the death so that they do not get in trouble for the death, but later they end up reporting the incident to Joan's parents and prayers are offered to Thomas Cantilupe for her recovery ${ }^{345}$ Flint argues that the neighbors wish to conceal the death in order to escape a coroners' inquest.

The idea that communities were supposed to support one another falls in line with Hanawalt's argument about peasant families relying on community support. While nuclear families formed emotional bonds in the household and worked together to keep the family intact, they relied on fellow-community members for additional support. Not only that, but they sometimes risked their lives or reputations for each other. Hanawalt gives examples of neighbors dying while trying to help others push wagons out of mud and people agreeing to be pledges for someone expected in court (pledges were fined if the person failed to go to court). Some neighbors even rallied together to support women, who were abused by their husbands. ${ }^{346}$

${ }^{344}$ Darlington, ed., Vita Wulfstani, 120-121.

${ }^{345}$ Flint, The Saint and the Operation of the Law, 345.

${ }^{346}$ Hanawalt, The Ties that Bound, 208, 258-259. 
Other textual evidence from the medieval period corroborates Hanawalt's argument that the community supported families, especially children in dangerous situations, even though they do always not contain descriptions of emotion. For example, community guardianship over children is also expressed in prayer books and priest manuals. In some regions, church authority took extra precautions for pregnant women and their unborn children by having parishioners recite prayers for them. In the diocese of York, for instance, parishioners prayed "that God comfort them and deliver them with joy, and send their children Christendom and the mothers purifying of Holy Church, and release of pain in their travailing." ${ }^{347}$ In Mirk's Instructions for Parish Priests, there is also evidence of concern for unborn children. Mirk writes that it was the responsibility of a midwife to deliver a healthy baby. The handbook contains a description of the sadness a midwife would experience if the birthing process did not go as planned. In a section about birth and baptism, Mirk instructs priests to warn midwives that if a newborn perished under their care, they would "wepen euer more" [weep for it evermore]. ${ }^{348}$ In other words, Mirk points out that midwives could feel responsible, and grieve, if they did not deliver healthy babies.

Legal texts, such as coroners' rolls, also corroborate the idea that communities valued and watched over children in medieval society. In the year 1339, John Fitz-John the coroner of Cambridgeshire writes about a well-related child death. He reports:

\footnotetext{
347 Thomas Simmons, ed., The Lay Folks Mass Book (London: The Early English Text Society, 1879), 71: pat god comforth pame and delyuer pam with ioy \&send pare childer cristendom \& pe moders purifying of holy kirk. and relese of payn in pare trauelyug.

${ }^{348}$ John Mirk, Instructions for Parish Priests, 4 (line 108).
} 
And they say on their oath that on Holy Thursday of the aforesaid year John, Ralph's son, went to play near a certain common well called the Townwell on a certain green in Weston Colville, and he fell slipping into the well by misadventure and was drowned. Therefore, it was ordered that the well be closed. ${ }^{349}$

The report from Cambridgeshire showcases communal reactions to child death, this time from a legal perspective. The description of the child death does not include great detail about how neighbors and family responded emotionally to John's death. In fact, the lion's share of the report includes details about the manner of death and a list of witnesses. Nevertheless, the last line of the report demonstrates that community action was taken to prevent future accidents in Weston Colville. Because the well in Weston Colville was not a portable object, such as a knife, it is no surprise that it could not be removed to be forfeited to the royal treasury. The fact that it was required to be filled in immediately after the accident, demonstrates that the community saw it fit to prevent other accidents from happening. Therefore, even though details about the emotional dialogue of community members is omitted, it is still clear that medieval people, including legal authority, valued children enough to take steps to ensure their safety and acted as their protectors.

${ }^{349}$ Charles Gross, ed., Select Cases from the Coroners' Rolls A. D. 1265-1413 with a Brief Account of the History of the Office of Coroner (London, 1896), 40-42: "Qui dicunt super sacramentum suum quod predicto die Jovis in festo Ascenciounis Domini anno supradicto predictus Johannes filius Radulphi ivit ludendo juxta quondam communem puteum vocatum Tonewalle in quadam virida placea in Westone Coleville, et cespitavit et per infortunium cecidit in predictum puteum et ibidem submersit. Ideo perceptum est obstupare predictum puteum." 
Even when children perished, communities continued to care for their spiritual well-being through commemoration. Children were depicted on brasses when they perished, or with family that perished with them. One example of the former type of brass is as the chrisom brass of Thomas Greville (1492), the son of a merchant, behind the altar at St. Margaret's Church, Stanford Rivers, Essex (See Image 1).

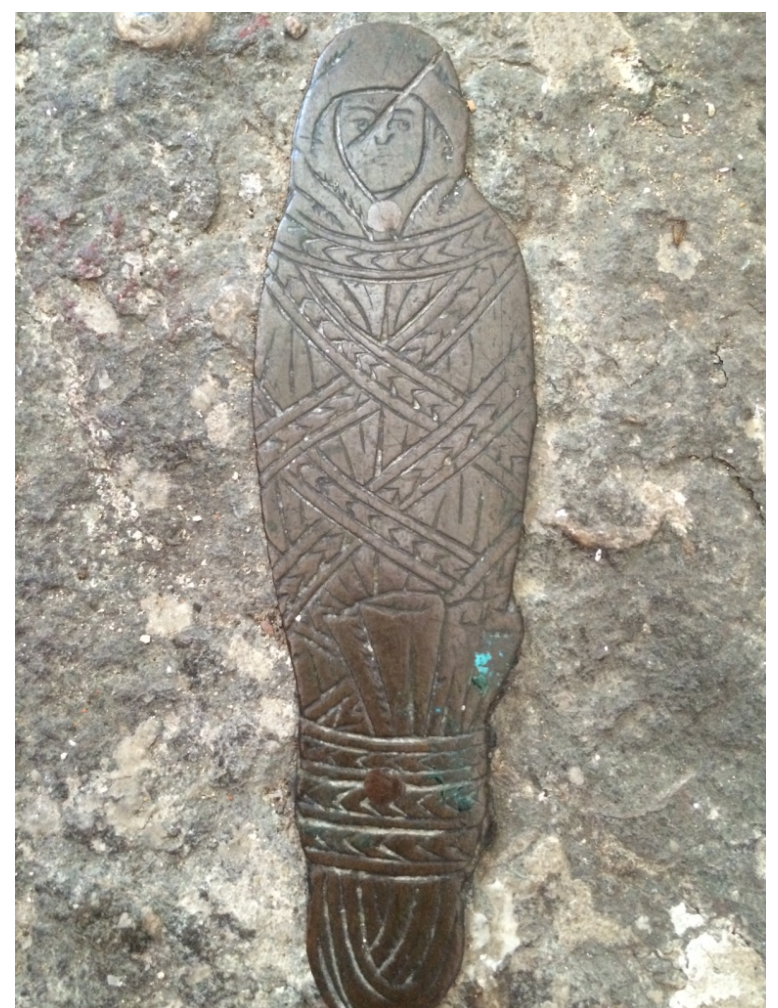

Image 1: The Chrisom Brass of Thomas Greville (d. 1492), the son of a London merchant, which is located behind the altar at St. Margaret's Church, Stanford Rivers, Essex. The engraving depicts an infant in swaddling garb, with bands across the swaddling clothing. Photograph by Danielle Griego.

Chrisom brasses contained engravings of infants donning either swaddling clothes or baptismal garb. The infant on the Thomas Greville brass wears swaddling clothes with crisscrossing swaddling bands wrapped from under the neck to the top of the feet. Initially, scholars believed that brasses such as these indicated that children had died 
before or quickly after baptism. Sophie Oosterwijk has shown that brasses of this nature signaled that a child died at a young age, not necessarily in the moments surrounding baptism. ${ }^{350}$ Therefore, children buried under these memorials could have lived well-past baptism.

Gilchrist argues that the dead had their own distinct community within the medieval social hierarchy because death was intertwined with the physical realm. Medieval people looked to the "good" dead, such as saints, for help in daily affairs, held markets and celebrations in cemeteries, and mourned and remembered those who perished, both adults and children, in parish masses. ${ }^{351}$ Deceased children would have been part of this otherworldly community. Like the authors writing about child death in miracle stories, engravers would have contributed to the memory of lost children. Thomas Greville's brass in particularly would have held a special place in his communities' memory because the memorial sat just behind the altar, as close to the sacred as one could get. These types of brasses would have also served as physical displays and reminders of grief. Brasses did not only represent status as some archaeologists would argue. Families would have commissioned these brasses out of the love that they had for their children, and also because they grieved their loss.

Furthermore, the brasses would have acted as reminders of grief for communities. People would have seen memorial brasses and be reminded of children that left the physical world behind.

\footnotetext{
${ }^{350}$ Sophie Oosterwijk, "Chrysoms, shrouds and infants on English Tomb Monuments: A question of terminology?," Church Monuments 15 (2000): 44-64.

${ }^{351}$ Gilchrist, Medieval Life, 180.
} 


\section{CONCLUSION}

Miracle stories involving child death demonstrate that religious men encouraged communities to treat children with compassion and protect them from harm. Children formally entered a community after they were born and medieval community members, along with their parents, were expected to take steps to ensure that a child's identity lived on. This supports Hanawalt's idea that communities worked as support networks to families. Miracle writers mirrored this idea in their stories and depicted communities as playing active roles in child death accounts. This is seen in all the miracle narratives, even the Simon de Montfort collection where the language of grief is not put forth. Relatives of deceased children turned to neighbors and bystanders for advice, and members of communities gathered at death locations, sometimes assuming the role of guardian when parents were absent or incapable of helping their children. Fellow community members also mourned with families that lost children. Authors emphasized the emotion of grief not only to put forth the message that children were valued, but also to underscore the idea that neighbors should work together in order help children and their families in times of need. In the Wulfstan, Thomas of Cantilupe, Thomas of Becket, and Henry VI miracles, community members are either described as being a part of a crowd or as individuals performing religious acts on behalf of deceased children or as attempting to revive them through physical means. Authors of the Wulfstan and Henry VI collections, highlight the theme of "unity" through the idea of working in unison, while authors of Thomas Becket and Thomas of Cantilupe miracles show communities praying and working together to create the image of solidarity within their works. Communities 
also showed concern and grief for unborn children and prayed for their safe entrance into the world. They also attempted to eliminate hazards, such as wells, in order to ensure child safety. What is more, they continued to care for children and remember grief long after a child had died. Memorial brasses were erected on their behalf and because this, children became part of the spiritual memories of communities and reminded those communities about the fragility of childhood. The intervention of community members in child death suggests that not only parents were expected to have emotional attachments to their children but also that medieval communities were expected to not treat children as social "others," but rather as vital members of society. ${ }^{352}$

352 Some of the research in this chapter can also be seen in my forthcoming article called "It Takes a Village: Community Responses to Child Death in High and Late Medieval England," in Explorations of Medieval Culture (Brill, forthcoming), ed. Mary Valante. 


\section{CONCLUSION}

Child mortality was high in medieval England. Children perished from complications during birth and postpartum. Those who survived the birthing process could still succumb to illness and accidental deaths around the household and community. Children in cities died while playing in the streets, from animal bites, and performing every day activities, such as walking up and down stairs. Children in villages received fatal injuries when performing household chores, such as gathering water for laundry and cooking, and herding animals across bodies of water. Periods of famine and waves of the Black Death undoubtedly increased death rates, both for children and adults. Ariès' and Stone's argument that parents and members of the wider community were "numb" to child death because of its frequency, have long been dismissed by historians such as Hanawalt, Finucane, Orme, Gordon, and Shahar (to name only a few). These historians have pointed out not only that members of communities cared about one another, but also that they valued children and normally mourned their deaths no matter how much death they witnessed in their lives. Community members would have been in constant contact with one another and formed emotional bonds on a daily basis. People would have seen each other at mass or religious festivals, while conducting business, performing legal duties, conversing with neighbors, working in fields, and at communal wells.

Despite the recognition that parents were not numb to the deaths of their offspring and the continual growth of childhood studies, analysis of the reactions to child death remains outside the scope of historical scholarship. Historians like Orme, Hanawalt, and 
Finucane describe different aspects of childhood, such as the birthing process, rites of passage ceremonies, and types of injuries and deaths that plagued children throughout the Middle Ages. The main focus of their works is to describe childhood and also point out the fallacy of Ariès' arguments. They show that people tried to revive children when they were sick, that parents cared enough for children to educate them, that communities integrated children into their communities early on in life with rites of passage ceremonies, and that the nuclear family relied on the community for help with children. Yet, they do not go into great detail about how communities responded to their deaths, or how medieval writers depicted those reactions. The topic of emotions has also become prominent within the field of medieval studies. Hansen has looked at emotional ties between Icelandic children and their foster parents, and many scholars have looked at the tears of Margery Kempe and courtly emotion within Arthurian literature. Rosenwein in particular has single-handedly changed the way that historians view emotion of the past. She argues that people should investigate emotional communities, which were groups of people that had similar ideals for emotional expression. Emotional communities could be as big as an entire royal court or as small as a peasant household. Although the study of emotions is becoming more and more popular and new methods of looking at emotions of the past have emerged, emotional responses to child death, specifically grief, have not examined closely within this field.

This dissertation was mainly inspired by Rosenwein's studies and also the work of Finucane and Gordon. I expand the discussion of childhood, specifically the study of accounts of child death in Finucane and Gordon's works. I go beyond arguing against Ariès and Stone or looking at descriptions of death and illness in order to understand the 
ways in which children perished. Instead, I analyze emotional responses to child death. This work is also inspired by the various projects of Rosenwein. I use Rosenwein's idea that descriptions of emotions in medieval texts can be analyzed in order to better understand an author's expectations for medieval people, in this case religious writers' expectations for communities and parents in the wake of child death.

In this project, I argue that love for children and grief over child death is present in the medieval source record. Authors of miracles employed the emotion of grief in their stories in order to highlight strong mother-child bonds, as well as the expectations that they had for women and child care. Mothers were portrayed as grieving publically in the miracle collections of Wulfstan, Thomas Becket, Thomas of Cantilupe and Henry VI. When their children died, they cried out, groaned loudly, and shrieked. Sometimes maternal grief could be so overwhelming that women experienced episodes of madness and went into frenzies. This type of grief could lead to sin, such as contemplating selfharm or going against religious and legal protocol. Authors portrayed mothers as grieving in these ways in order to stress the guilt they felt for the deaths of their children, even when they were not directly the cause of the death. The application of guilt aligns with the idea that the materfamilias was largely in charge of the domestic sphere, including the safety of children. The sentiment that it was a mother's responsibility to watch over children has been addressed by Herlihy and Shahar. Herlihy pointed out that, in Italian homes, fathers were much older than their wives and offspring, causing women to be mediators between children and heads of households. Shahar, on the other hand, notes that medieval texts promoted the idea of woman as domestic overseer. Encyclopedias, such as the one written by Bartholomeus Anglicus, specifically stated that women were 
the more nurturing of the sexes and were therefore in charge of childcare. Bartholomew of Exeter also stressed the idea that mother's responsibility to watch over children and to claim culpability if they perished under their care. Medieval lyrics also depicted the Virgin Mary as publically mourning Christ's death, both when she heard the prophecy of his tragic fate and when she watched him dying on the Cross. The imagery of the Holy Mother mourning showcases her love for Christ, and also her desire to protect him from harm. Medieval mothers would have read or heard these lyrics and would have absorbed the idea that they needed to protect their children, as Mary tried to do for her child.

Grief is also mentioned in miracle accounts involving fathers. Authors of miracles also depicted fathers in the miracles of Henry VI, Wulfstan, Thomas Becket, Simon de Montfort, and Thomas of Cantilupe as grieving outwardly. They shed fountains of tears, wailed, and sighed and groaned. However, although their grief was expressed outwardly, it typically did not attract the attention of neighbors and blame for child death was never attached to their sadness. They also, in some cases, practiced emotional restraint when their children died. Instead of grieving publically, they prayed, made religious vows, and went on with daily affairs. When fathers grieved immoderately, authors criticized them in order to point out that excessive grief could lead to turning one's back to religion and stepping out of the role of paterfamilias. Herlihy and Hanawalt make it clear that the role of paterfamilias was important to the medieval household. Hanawalt argues that the nuclear family thrived on the partnership model of marriage, meaning that labor and household roles were divided between husband and wife. Still, the head of household was at the top of the hierarchy. The head of household was supposed to ensure the harmony of the nuclear family. If grief clouded this role, the household could potentially be turned 
upside down. Moreover, grief could cloud one's judgement about religion. Hanegbi contends that medieval people were concerned about excessive grief, specifically how excessive grief could lead someone astray from their faith. Excessive grief could cause melancholia, a state of despair that could end in suicide. What is more, excessive grief could cause one to question why God did not save their loved ones or obsess over the physical realm. The authors of Brome Abraham and Isaac and the Middle English Pearl corroborated the idea that excessive grief could lead one astray from God. Abraham grieves so much over the thought of killing his son, Isaac, that he continually sins. So much so, that Isaac has to encourage him to follow through with the task in order to rectify his priorities. The Dreamer in the Pearl, too, is consumed with grief over the loss of his daughter. It courses through his body, making his heart hurt. Similar to Isaac in the mystery play, the Dreamer's daughter is the one to tell him that he needs to stop grieving. She scolds him, telling him that he must honor God during good times and bad in order to gain heavenly rewards.

Authors of miracle stories also depicted community members as interacting with people who had lost children. The Simon de Montfort collection showed that it was expected that people go to neighbors for help and advice when children died. In the other miracle collections, communities are portrayed as interacting with grieving parents and participating in the mourning process. Miracle writers used grief to put forth the idea that communities valued children and were supposed to help fellow-community members in need. Grief acted as a cue for community members to come to the scene of a death and either try to help revive a child or grieve with distraught relatives or caretakers. Authors portrayed the idea that communities were also supposed to step in and act as guardians 
when caretakers or relatives of children were absent or unable to save them from death. These accounts reinforce Hanawalt's conclusion that medieval families relied on the wider community in times of crisis. While the nuclear family thrived on its own, it still needed the help of others when children were left unsupervised or when parents did not what to do in the face of child death. Concern for children by community members extends beyond miracle stories and can be found in other texts as well as material evidence. Prayer books show that parishioners prayed for the safety of unborn children. Medical texts prepared physicians and midwives for the dangers of childbirth and cautioned mothers to stay healthy during pregnancy. Communities took legal measures to keep children safe from hazards around the community. Even in death children were looked after. Engravers contributed to the memory of children through commemorative brasses, called family and chrisom brasses. When seeing these brasses, parishioners would not only have prayed for the safety of children in the afterlife, but would have been constantly reminded of the sadness that their deaths brought upon the community.

By looking at both the textual and material evidence about emotion towards child death, this project contributes to the field of childhood studies and the history of emotion. Furthermore, the study helps us better understand expectations about childrearing, religion, the role of paterfamilias, community intervention, and reactions to death. Mothers were expected to vigilantly watch over their offspring, and fathers were to maintain harmony within the household and keep religion at the forefront of the mind. Both were supposed to love their children. Communities were supposed to value children and assume guardianship over them when parents failed in their duties or when they were too grief-stricken to react properly. Medieval people were not supposed to be the numb or 
indifferent individuals that Stone and Ariès made them out to be, but rather, networks of people, full of feeling, working together to raise and keep children safe from the dangers that lurked around every corner. 


\section{APPENDIX 1}

(Chart of miracles that mention parents, community, or other guardians. Check mark indicates what type of grief is in each account. )

\begin{tabular}{|c|c|c|c|c|c|}
\hline Child & $\begin{array}{l}\text { Miracle } \\
\text { Collection }\end{array}$ & $\begin{array}{l}\text { Paternal } \\
\text { Grief }\end{array}$ & $\begin{array}{c}\text { Maternal } \\
\text { Grief }\end{array}$ & $\begin{array}{c}\text { Relative/ } \\
\text { Caretaker }\end{array}$ & $\begin{array}{l}\text { Community } \\
\text { Involvement }\end{array}$ \\
\hline Phillip from Cheshire & $\begin{array}{l}\text { Thomas } \\
\text { Becket }\end{array}$ & $\begin{array}{l}\checkmark \text { Sighs and } \\
\text { groans }\end{array}$ & $\begin{array}{c}\checkmark \text { Cries and } \\
\text { wails in } \\
\text { public }\end{array}$ & & \\
\hline Phillip from Cheshire & $\begin{array}{l}\text { Thomas } \\
\text { Becket }\end{array}$ & $\begin{array}{c}\checkmark \text { Hugh } \\
\text { prays }+ \\
\text { Becket Water }\end{array}$ & $\begin{array}{c}\checkmark \text { Both } \\
\text { parents are } \\
\text { anxious after } \\
\text { death }\end{array}$ & & \\
\hline Cradle death, mother Sybil & $\begin{array}{l}\text { Thomas of } \\
\text { Cantilupe }\end{array}$ & & $\checkmark$ Cries & & \\
\hline Bath death, with nurse & Wulfstan & & & $\begin{array}{l}\checkmark \text { Nurse } \\
\text { flees }\end{array}$ & $\begin{array}{l}\checkmark \text { Community } \\
\text { decides what to do } \\
\text { with infant, while } \\
\text { nurse leaves the } \\
\text { scene out of fear }\end{array}$ \\
\hline Girl from Northwood & $\begin{array}{l}\text { Thomas } \\
\text { Becket }\end{array}$ & & $\begin{array}{l}\checkmark \text { Mother } \\
\text { cries and } \\
\text { prays to } \\
\text { Thomas in } \\
\text { public }\end{array}$ & & $\begin{array}{l}\checkmark \text { Community } \\
\text { watches mother } \\
\text { grieve }\end{array}$ \\
\hline Boy in Northamptonshire & $\begin{array}{l}\text { Thomas } \\
\text { Becket }\end{array}$ & & $\begin{array}{c}\checkmark \text { Mother } \\
\text { sighs and } \\
\text { utters pleas } \\
\text { for help }\end{array}$ & & \\
\hline $\begin{array}{l}\text { Mill-Wheel death in } \\
\text { Lichfield }\end{array}$ & $\begin{array}{l}\text { Thomas } \\
\text { Becket }\end{array}$ & & $\begin{array}{l}\checkmark \text { Mother } \\
\text { cries out }+ \\
\text { onlookers } \\
\text { hear her } \\
\text { screams }\end{array}$ & & $\begin{array}{c}\sqrt{ } \text { Onlookers hear } \\
\text { mother's cries }\end{array}$ \\
\hline $\begin{array}{l}\text { Robert Medway River } \\
\text { death }\end{array}$ & $\begin{array}{l}\text { Thomas } \\
\text { Becket }\end{array}$ & & $\begin{array}{l}\checkmark \text { Mother } \\
\text { runs to child } \\
\text { and cries out } \\
\text { in distress. } \\
\text { Her cries are } \\
\text { repeated over } \\
\text { and over in } \\
\text { front of } \\
\text { everyone }\end{array}$ & & $\begin{array}{l}\sqrt{ } \text { Bystanders hear } \\
\text { mother repeating } \\
\text { please to Becket }\end{array}$ \\
\hline
\end{tabular}




\begin{tabular}{|c|c|c|c|}
\hline $\begin{array}{l}\text { Boy dies in Worcester } \\
\text { from illness }\end{array}$ & Wulfstan & $\begin{array}{c}\sqrt{ } \text { Mother } \\
\text { cries and } \\
\text { groans, } \\
\text { community } \\
\text { grieves with } \\
\text { her }\end{array}$ & \\
\hline Droitwich well death & Wulfstan & $\begin{array}{c}\checkmark \text { Mother } \\
\text { cries out } \\
\text { +horrible } \\
\text { cries fill the } \\
\text { neighborhood }\end{array}$ & \\
\hline $\begin{array}{l}\text { Gilbert dies in rainwater } \\
\text { bin, London }\end{array}$ & $\begin{array}{l}\text { Thomas of } \\
\text { Cantilupe }\end{array}$ & $\begin{array}{l}\checkmark \text { Neighbor } \\
\text { walking } \\
\text { outside hears } \\
\text { woman } \\
\text { crying over } \\
\text { dead child }\end{array}$ & $\begin{array}{c}\sqrt{ } \text { Neighbor enters } \\
\text { friend's house when } \\
\text { she hears her } \\
\text { crying }\end{array}$ \\
\hline $\begin{array}{l}\text { Two-year -old almost dies } \\
\text { in house fire in Stoneley }\end{array}$ & Henry VI & $\begin{array}{l}\checkmark \text { Mother } \\
\text { cries and } \\
\text { village } \\
\text { gathers +runs } \\
\text { into house to } \\
\text { save child }\end{array}$ & $\begin{array}{c}\checkmark \text { Community } \\
\text { watches woman } \\
\text { grieve }\end{array}$ \\
\hline Ersandis overlaying & Edmund Rich & $\begin{array}{c}\sqrt{ } \text { Episode of } \\
\text { madness } \\
\text { +attempt at } \\
\text { suicide }\end{array}$ & \\
\hline $\begin{array}{l}\text { Mother from Worcester } \\
\text { goes mad with grief when } \\
\text { daughter dies }\end{array}$ & Wulfstan & $\begin{array}{l}\checkmark \text { Mother } \\
\text { goes mad } \\
\text { from sadness, } \\
\text { does not } \\
\text { recognize } \\
\text { anyone }\end{array}$ & \\
\hline Margery cradle mishap & $\begin{array}{l}\text { Thomas of } \\
\text { Cantilupe }\end{array}$ & $\begin{array}{l}\checkmark \text { Mother } \\
\text { cries and } \\
\text { howls with } \\
\text { grief }\end{array}$ & $\begin{array}{c}\sqrt{ } \text { Neighbors hear } \\
\text { howls and } \\
\text { congregate at the } \\
\text { scene }\end{array}$ \\
\hline $\begin{array}{c}\text { Son of Matilda dies of } \\
\text { hernia }\end{array}$ & $\begin{array}{l}\text { Thomas } \\
\text { Becket }\end{array}$ & $\begin{array}{l}\checkmark \text { Mother } \\
\text { laments and } \\
\text { asks what } \\
\text { sins she has } \\
\text { committed to } \\
\text { lose her child }\end{array}$ & \\
\hline $\begin{array}{c}\text { George dies from } \\
\text { swaddling accident in } \\
\text { Brackley }\end{array}$ & Henry VI & $\begin{array}{c}\checkmark \text { Mother } \\
\text { erupts into } \\
\text { tears, face is } \\
\text { drenched in } \\
\text { tears + does } \\
\text { not follow } \\
\text { legal or } \\
\text { religious } \\
\text { protocol }\end{array}$ & $\begin{array}{l}\sqrt{ } \text { Neighbors hear } \\
\text { her cries and come } \\
\text { over to see what's } \\
\text { going on. This is } \\
\text { what makes her stay } \\
\text { at the death scene. }\end{array}$ \\
\hline
\end{tabular}




\begin{tabular}{|c|c|c|c|c|}
\hline $\begin{array}{l}\text { Jordan's son dies from } \\
\text { illness }\end{array}$ & $\begin{array}{l}\text { Thomas } \\
\text { Becket }\end{array}$ & $\begin{array}{c}\checkmark \text { Cries } \\
\text { +author states } \\
\text { both parents } \\
\text { grieve } \\
\text { +restrains } \\
\text { grief in front } \\
\text { of guests }\end{array}$ & $\begin{array}{c}\checkmark \text { Mother } \\
\text { grieves over } \\
\text { death }\end{array}$ & $\begin{array}{l}\checkmark \text { Pilgrims } \\
\text { congregate at } \\
\text { Jordan's house }\end{array}$ \\
\hline $\begin{array}{c}\text { Jordan's son dies from } \\
\text { illness }\end{array}$ & $\begin{array}{l}\text { Thomas } \\
\text { Becket }\end{array}$ & $\begin{array}{l}\checkmark \text { Prays to } \\
\text { Becket for } \\
\text { son's } \\
\text { recovery }\end{array}$ & & \\
\hline $\begin{array}{l}\text { John Searle dies from } \\
\text { being gored by ox }\end{array}$ & Henry VI & $\begin{array}{c}\checkmark \text { Father } \\
\text { shakes, has a } \\
\text { broken heart, } \\
\text { has a fountain } \\
\text { of tears, and } \\
\text { makes plea to } \\
\text { Henry VI }\end{array}$ & & \\
\hline $\begin{array}{l}\text { Eudes of Parndon's son } \\
\text { dies from illness }\end{array}$ & $\begin{array}{l}\text { Thomas } \\
\text { Becket }\end{array}$ & $\begin{array}{c}\checkmark \text { Goes into } \\
\text { garden to wail } \\
\text { +kneels to ask } \\
\text { Becket for } \\
\text { help }\end{array}$ & $\begin{array}{l}\checkmark \text { Mourns } \\
\text { amongst } \\
\text { neighbors }\end{array}$ & $\begin{array}{l}\sqrt{ } \text { Mother mourns } \\
\text { amongst neighbors }\end{array}$ \\
\hline $\begin{array}{l}\text { John, son of Phillipy, } \\
\text { drowns }\end{array}$ & $\begin{array}{l}\text { Simon de } \\
\text { Montfort }\end{array}$ & $\begin{array}{l}\checkmark \text { Father } \\
\text { cries and } \\
\text { groans while } \\
\text { carrying his } \\
\text { son } \\
\text { +measures } \\
\text { son to Simon } \\
\text { de Montfort }\end{array}$ & & \\
\hline $\begin{array}{l}\text { Alice dies on way to } \\
\text { pilgrimage }\end{array}$ & $\begin{array}{l}\text { Thomas of } \\
\text { Cantilupe }\end{array}$ & $\begin{array}{c}\checkmark \text { Father } \\
\text { measures } \\
\text { daughter, } \\
\text { bends penny } \\
\text { over her, and } \\
\text { vows } \\
\text { pilgrimage }\end{array}$ & & \\
\hline Felicia drowns in well & $\begin{array}{l}\text { Thomas of } \\
\text { Cantilupe }\end{array}$ & $\begin{array}{l}\checkmark \text { Father } \\
\text { measures her } \\
\text { to Thomas of } \\
\text { Cantilupe }\end{array}$ & & \\
\hline $\begin{array}{l}\text { Margaret of Hameldon's } \\
\text { dead unborn child }\end{array}$ & $\begin{array}{l}\text { Thomas } \\
\text { Becket }\end{array}$ & $\begin{array}{c}\checkmark \text { Father } \\
\text { vows } \\
\text { pilgrimage }\end{array}$ & $\begin{array}{l}\checkmark \text { Mother } \\
\text { mourns over } \\
\text { death of } \\
\text { unborn child }\end{array}$ & \\
\hline $\begin{array}{l}\text { Boy in Stepney dies when } \\
\text { falling off boat }\end{array}$ & Henry VI & $\begin{array}{l}\checkmark \text { Father } \\
\text { vows to not } \\
\text { eat meat }+ \\
\text { pilgrimage }\end{array}$ & & \\
\hline
\end{tabular}




\begin{tabular}{|c|c|c|c|c|c|}
\hline Cecilia dies from cancer & $\begin{array}{l}\text { Thomas } \\
\text { Becket }\end{array}$ & $\begin{array}{c}\checkmark \text { Father } \\
\text { faints from } \\
\text { grief + shouts } \\
+ \text { angrily } \\
\text { pleas with } \\
\text { Becket to } \\
\text { save daughter }\end{array}$ & & & \\
\hline $\begin{array}{l}\text { Stillborn child of Alan of } \\
\text { Burton }\end{array}$ & $\begin{array}{l}\text { Thomas } \\
\text { Becket }\end{array}$ & $\begin{array}{c}\checkmark \text { Howls } \\
\text { and talks } \\
\text { about misery } \\
+ \text { Author calls } \\
\text { him } \\
\text { "womanly" } \\
\text { for his grief }\end{array}$ & & & \\
\hline $\begin{array}{c}\text { Knight of Ferring has dead } \\
\text { child }\end{array}$ & $\begin{array}{l}\text { Thomas } \\
\text { Becket }\end{array}$ & $\begin{array}{c}\checkmark \\
\text { Overwhelmed } \\
\text { with grief and } \\
\text { doesn't know } \\
\text { how to save } \\
\text { child }\end{array}$ & & & \\
\hline $\begin{array}{c}\text { Elinor has trouble giving } \\
\text { birth }\end{array}$ & $\begin{array}{l}\text { Thomas } \\
\text { Becket }\end{array}$ & $\begin{array}{l}\checkmark \text { Father } \\
\text { puts relic on } \\
\text { laboring } \\
\text { mother }\end{array}$ & & & \\
\hline $\begin{array}{l}\text { Beatrice dies when a tree } \\
\text { trunk falls on her }\end{array}$ & Henry VI & $\begin{array}{c}\checkmark \text { Father has } \\
\text { fountain of } \\
\text { tears, his } \\
\text { heart stings } \\
\text { + gives her to } \\
\text { mother } \\
\text { because he is } \\
\text { overwhelmed } \\
\text { with grief }\end{array}$ & $\begin{array}{l}\checkmark \text { Mother } \\
\text { takes child to } \\
\text { church in } \\
\text { order to } \\
\text { restore her } \\
\text { life }\end{array}$ & & \\
\hline $\begin{array}{c}\text { Man grieves over death of } \\
\text { his child, persistent in } \\
\text { tears }\end{array}$ & $\begin{array}{l}\text { Thomas } \\
\text { Becket }\end{array}$ & $\begin{array}{l}\checkmark \text { Child } \\
\text { perishes at } \\
\text { night, man is } \\
\text { persistent in } \\
\text { tears and } \\
\text { invokes } \\
\text { Becket }\end{array}$ & & & \\
\hline Boy dies in cave & $\begin{array}{l}\text { Thomas } \\
\text { Becket }\end{array}$ & $\begin{array}{l}\checkmark \text { Father } \\
\text { recounts } \\
\text { asking Becket } \\
\text { for help }\end{array}$ & & & \\
\hline $\begin{array}{l}\text { Mill-Wheel death in } \\
\text { Westwell }\end{array}$ & Henry VI & & & $\begin{array}{c}\quad \checkmark \\
\text { Grandfather } \\
\text { full of tears }\end{array}$ & $\begin{array}{c}\checkmark \text { Neighbors try to } \\
\text { help save child }+ \\
\text { mourns and prays } \\
\text { together }\end{array}$ \\
\hline Gilbert Sarre dies in bath & $\begin{array}{l}\text { Thomas } \\
\text { Becket }\end{array}$ & & $\begin{array}{l}\sqrt{ } \text { Mother } \\
\text { cries out }\end{array}$ & & $\begin{array}{l}\checkmark \text { Neighbors } \\
\text { attempt to revive } \\
\text { child }\end{array}$ \\
\hline
\end{tabular}




\begin{tabular}{|c|c|c|c|c|c|}
\hline $\begin{array}{l}\text { Hugh and Emma lose son } \\
\text { from illness }\end{array}$ & Wulfstan & $\begin{array}{c}\checkmark \text { Both } \\
\text { parents have } \\
\text { strange cries }\end{array}$ & $\begin{array}{c}\checkmark \text { Both } \\
\text { parents have } \\
\text { strange cries }\end{array}$ & & $\begin{array}{l}\checkmark \text { Neighbors run } \\
\text { to strange cries }\end{array}$ \\
\hline Joan hangs herself & Henry VI & & $\begin{array}{l}\checkmark \text { Mother } \\
\text { grieves }\end{array}$ & & $\begin{array}{c}\checkmark \text { Neighbors } \\
\text { gather around child } \\
\text { and pray together }\end{array}$ \\
\hline Margaret dies in fishpond & Henry VI & $\begin{array}{c}\checkmark \text { Parents } \\
\text { mourn death } \\
\text { together }\end{array}$ & $\begin{array}{l}\checkmark \text { Parents } \\
\text { mourn death } \\
\text { together }\end{array}$ & & $\begin{array}{l}\checkmark \text { Neighbors feel } \\
\text { fear, heaviness, and } \\
\text { mourn with parents } \\
\text { +ask for divine help }\end{array}$ \\
\hline Benedicta falls on knife & Henry VI & $\begin{array}{c}\checkmark \text { Both } \\
\text { parents mourn }\end{array}$ & $\begin{array}{l}\checkmark \text { Both } \\
\text { parents } \\
\text { mourn }\end{array}$ & & $\begin{array}{c}\checkmark \text { Neighbors } \\
\text { gather and pray }+ \\
\text { make promises to } \\
\text { Henry VI in } \\
\text { exchange for divine } \\
\text { intervention }\end{array}$ \\
\hline Anne crushed by cart & Henry VI & & $\begin{array}{l}\checkmark \text { Mother } \\
\text { runs after cart } \\
\text { driver to yell } \\
\text { at him }\end{array}$ & & $\begin{array}{c}\checkmark \text { Agnes bends } \\
\text { penny over child } \\
\text { and inspires crowd } \\
\text { to pray }\end{array}$ \\
\hline $\begin{array}{c}\text { Thomas Scott falls from } \\
\text { tree }\end{array}$ & Henry VI & & & $\begin{array}{l}\checkmark \text { Abbess } \\
\text { almost faints } \\
\text { with grief }\end{array}$ & $\begin{array}{c}\checkmark \text { Community at } \\
\text { Windsor runs } \\
\text { around }+ \text { tries to } \\
\text { revive child. Abbess } \\
\text { inspires nuns to } \\
\text { pray for } \\
\text { intervention }\end{array}$ \\
\hline $\begin{array}{l}\text { Girl from Kent falls into } \\
\text { well }\end{array}$ & Henry VI & & & $\begin{array}{l}\sqrt{ } \text { Mistress } \\
\text { calls for help }\end{array}$ & $\begin{array}{c}\checkmark \text { Neighbor saves } \\
\text { child from well }+ \\
\text { makes vows and } \\
\text { inspires prayer }\end{array}$ \\
\hline $\begin{array}{c}\text { William of Donnington } \\
\text { drowns }\end{array}$ & $\begin{array}{l}\text { Thomas of } \\
\text { Cantilupe }\end{array}$ & $\begin{array}{l}\checkmark \text { Father } \\
\text { filled with } \\
\text { grief + keeps } \\
\text { dinner plans }\end{array}$ & & & $\begin{array}{l}\sqrt{ } \text { Community } \\
\text { member tries to } \\
\text { revive boy and } \\
\text { encourages others } \\
\text { to pray +community } \\
\text { weeps }\end{array}$ \\
\hline $\begin{array}{c}\text { Nicholas drowns in How } \\
\text { Caple }\end{array}$ & $\begin{array}{l}\text { Thomas of } \\
\text { Cantilupe }\end{array}$ & $\begin{array}{l}\checkmark \text { Parents } \\
\text { faint from } \\
\text { grief }\end{array}$ & $\begin{array}{l}\checkmark \text { Parents } \\
\text { faint from } \\
\text { grief }\end{array}$ & & $\begin{array}{c}\checkmark \text { Two community } \\
\text { members try to help } \\
\text { both parents and } \\
\text { Nicholas }\end{array}$ \\
\hline $\begin{array}{l}\text { Woman is dying after } \\
\text { labor and child born dead }\end{array}$ & $\begin{array}{l}\text { Simon de } \\
\text { Montfort }\end{array}$ & & & & $\begin{array}{l}\checkmark \text { Midwives } \\
\text { suggest woman call } \\
\text { on Simon de } \\
\text { Montfort as she dies } \\
\text { after labor and child } \\
\text { is born dead }\end{array}$ \\
\hline
\end{tabular}




\begin{tabular}{|c|c|c|c|c|}
\hline Son drowns in fountain & $\begin{array}{l}\text { Simon de } \\
\text { Montfort }\end{array}$ & & & $\begin{array}{l}\checkmark \text { Bystanders } \\
\text { suggest the boy be } \\
\text { measured to Simon } \\
\text { de Montfort }\end{array}$ \\
\hline Son appears dead & $\begin{array}{l}\text { Simon de } \\
\text { Montfort }\end{array}$ & & & $\begin{array}{c}\checkmark \text { Community } \\
\text { members judge boy } \\
\text { to be dead }\end{array}$ \\
\hline $\begin{array}{c}\text { Alexander de Ross lies } \\
\text { dead }\end{array}$ & $\begin{array}{l}\text { Simon de } \\
\text { Montfort }\end{array}$ & & & $\begin{array}{c}\checkmark \text { Community } \\
\text { members judge boy } \\
\text { to be dead }\end{array}$ \\
\hline $\begin{array}{c}\text { Robert de Gainages son } \\
\text { dead }\end{array}$ & $\begin{array}{l}\text { Simon de } \\
\text { Montfort }\end{array}$ & $\begin{array}{c}\checkmark \text { Father } \\
\text { measures boy } \\
\text { to saint }\end{array}$ & & \\
\hline Girl dies from illness & $\begin{array}{l}\text { Simon de } \\
\text { Montfort }\end{array}$ & & & $\begin{array}{c}\checkmark \text { Girl judged } \\
\text { dead by neighbors }\end{array}$ \\
\hline Henry dies from illness & $\begin{array}{l}\text { Simon de } \\
\text { Montfort }\end{array}$ & & & $\begin{array}{c}\checkmark \text { Confirmed dead } \\
\text { by neighbors }+ \text { they } \\
\text { measure him to the } \\
\text { saint }\end{array}$ \\
\hline Stephen appears dead & $\begin{array}{l}\text { Simon de } \\
\text { Montfort }\end{array}$ & & & $\begin{array}{c}\checkmark \text { Confirmed dead } \\
\text { by community } \\
\text { members }\end{array}$ \\
\hline Elianor drowns & $\begin{array}{l}\text { Simon de } \\
\text { Montfort }\end{array}$ & & $\begin{array}{c}\checkmark \text { Mother } \\
\text { measures } \\
\text { daughter to } \\
\text { Simon de } \\
\text { Montfort }\end{array}$ & \\
\hline
\end{tabular}


Bibliography

\section{Printed Primary Sources}

Anglicus, Bartholomaeus. On the Properties of Things: John Trevisa's Translation of Bartholomaeus Anglicus De Propietatibus Rerum. Edited by Michael Seymor et al. Oxford: Clarendon Press, 1975.

Bibbesworth, of Walter. Le Tretiz. Edited by William Rothwell. London: Anglo-Norman Text Society, 1990.

Bolland, Jean et al. Acta Sanctorum. Paris: Society of Jesuit Theology,1865.

Burton, Thomas. Chronica Monasterii de Melsa, a Fundatione Usque ad Annum 1396, Vol. 3. Edited by Edward Bond. Cambridge: Cambridge University Press, 2012.

Canterbury, of William. Materials for the History of Thomas Becket, Archbishop of Canterbury, Canonized by Pope Alexander III, A. D. 1173, Vol. 1. Edited by James Robertson. London: Eyre and Spottiswoode, 1875.

Coldewey, John, ed., Early English Drama: An Anthology. New York: Garland Publishing, 1993.

Collin, Jefferies, ed., Manuale ad Vsum Percelebris Ecclesie Sarisburiensis. Henry Bradshaw Society 91. Chicester: Moore \& Tillyer, 1990.

Davies, Reginald, ed., Medieval English Lyrics: A Critical Anthology. London: Northwestern University Press, 1964.

Douay-Rheims. Gospel According to Luke 2. 35: drbo.org.

Douay-Rheims. Genesis 22. 3: drbo.org.

Douay-Rheims. Genesis 22.9-10: drbo.org.

Douis, Decima, and David Farmer, eds. and trans., Magna Vita Sancti Hugonis: The Life of St. Hugh of Lincoln, Vol. 1. Oxford: Oxford University Press, 1961.

Furnivall, Frederick ed., Hali Meidenhad: An Alliterativce Homily of the Thirteenth Century. Early English Text Society. New York: Greenwood Press, 1969.

Grosjean, Paul ed., Henrici VI Angliae Regis Miracula Postuma. Brussels: Society of the Bollandists, 1935. 
Gross, Charles, ed., Select Cases from the Coroners Rolls A. D. 1265-1413 with a Brief Account of the History of the Office of Coroner. London: The Selden Society, 1896.

Halliwell, James ed., The Chronicle of William de Rishanger; The Miracles of Simon de Montfort. Camden Society, Vol. 15. London: John Nichols and Son, 1840.

Halliwell, James, and Thomas Wright, eds., Reliquice Antiquae. Vol. 1. London: John Russell Smith, 1845.

Hunnisett, Roy, trans., Bedfordshire Coroners' Rolls. Bedfordshire Historical Record Society 41. Streatly: Bedforshire Historical Record Society Publications, 1961.

John Leland, De Rebus Britannicis Collectanea, Vol. 4. Edited by Thomas Hearne. London: Impensis Gul \& Jo. Richardson, 1770.

Knox, Ronald, and Shane Leslie, eds., The Miracles of King Henry VI. Cambridge: Cambridge University Press, 1923.

Lawrence, Hugh, trans., St. Edmund of Abingdon: A Study in Hagiography and History. Oxford: Clarendon Press, 1960.

Malmesbury, of William. The Vita Wulfstani of William of Malmesbury: To which are added the Extent Abridgements of this Work and the Miracles and Translation of St. Wulfstan. Royal Historical Society Camden Third Series. Edited and Translated by Reginald Darlington Vol. 40. London, Office of the Society, 1928.

Morey, Dom ed., Bartholomew of Exeter, Bishop and Canonist: A Study in the Twelfth Century. Cambridge: Cambridge University Press, 1937.

Monmouth, of Thomas. The Life and Miracles of St. William of Norwich. Edited by Augustus Jessop. Cambridge: Cambridge University Press, 1896.

Paris, Mathew. Matthaei Parisiensis Chronica Majora, Vol. 5. Edited by Henry Luard. London: Eyre and Spottiswoode, 1880.

Peterborough, of Benedict. Materials for the History of Thomas Becket, Archbishop of Canterbury, Canonoized by Pope Alexander III, A. D. 1173, Vol. 2. Edited by James Robertson. London: Eyre and Spottiswoode, 1867.

Salter, Herbert, ed., Records of Medieval Oxford: Coroners' Inquests, the Walls of Oxford, Etc. Oxford: The Oxford Chronicle Company, LTD, 1912.

Saupe, Karen, Middle English Marian Lyrics. PhD diss., University of Rochester, 1996. 
Sharpe, Reginald, ed., Calendar of Coroners Rolls of the City of London A. D. 13001378. London: Richard Clay and Sons, Limited, 1913.

Simmons, Thomas, ed., The Lay Folks Mass Book. London: The Early English Text Society, 1879.

Stanbury, ed., Pearl. Middle English Text Series. University of Rochester Robbins Library Digital Projects: http://d.lib.rochester.edu/teams/text/stanbury-pearl

Stevick, Robert, ed., On Hundred Middle English Lyrics. Indianapolis: The BobbsMerrill Company, 1964.

Stubbs, William ed., Select Charters and Other Illustrations of English Constitutional History. Revised by Davis Carless. Oxford: The Clarendon Press, 1913.

\section{Printed Secondary Sources}

Andrew, Malcolm, and Ronald Waldron, eds. The Poems of the Pearl Manuscript: Pearl, Cleanness, Patience, Sir Gawain and the Green Knight. Berkeley: University of California Press, 1978.

Ariès, Philippe. Centuries of Childhood: A Social History of Family Life. Translated by Robert Baldick. New York: Random House, 1962.

Badham, Sally. "Evidence for the Minor Funerary Monument Industry 1100-1500." In Town and Country in the Middle Ages: Contrasts, Contacts, and Interconnections, 1100-1500. Edited by Christopher Dyer and Kate Giles. Leeds: Maney Publishing, 2006.

Balizet, Ariane. Blood and Home in Early Modern Drama: Domestic Identity on the Renaissance Stage. Routledge Studies in Renaissance Literature and Culture. New York: Routledge, 2014.

Bailey, Anne. "Lamentation Motifs in Medieval Hagiography." Gender and History 25, no. 3 (2013): 529-544.

Bakker-Mulder, Anneke, ed. Sanctity and Motherhood: Essays on Holy Mothers in the Middle Ages. New York: Garland Publishing, Inc., 1995

Bannister, Scott. Names and Naming Patters in England 1538-1700. Oxford: Clarendon Press, 1997.

Bartlett, Robert. The Hanged Man: A Story of Miracle, Memory, and Colonialism in the 
Middle Ages. Princeton: Princeton University Press, 2004).

Why Can the Dead Do Such Great Things?: Saints and Worshippers

from the Martyrs to the Reformation. Princeton: Princeton Universiyt Press, 2013.

Beattie, Cordelia, Charlotte Carpenter, et al. "The Later Medieval English Urban Household." History Compass 5, no. 1 (2006): 112-158.

Bialas, Zbigniew et al., eds., Culture and the Rites/Rights of Grief. Newcastle upon Tyne: Cambridge Scholars Publishing, 2013.

Biggs, Douglas, Katherine French, and Linda Mitchell, eds. The Ties that Bind: Essays in Medieval British History in Honor of Barbara Hanawalt. London: Routledge, 2011.

Boswell, John. The Kindness of Strangers: The Abandonment of Children in Western Europe from Late Antiquity to the Renaissance. Chicago: The University of Chicago Press, 1988.

Broadman, Steve, and Eila Williamson, eds., The Cult of Saints and the Virgin Mary in Medieval Scotland. Woodbridge: The Boydell Press, 2010.

Bühler, Curt. "Prayers and Charms in Certain Middle English Scrolls." Speculum 39, no. 2 (1964): 270-278.

Burrow, John. The Ages of Man: A Study in Medieval Writing and Thought. Oxford: Oxford University Press, 1986.

Butler, Sara. "Degrees of Culpability: Suicide Verdicts, Mercy, and the Jury in the Medieval England." Journal of Medieval and Early Modern Studies 36, no. 2 (2006), 263-290.

. "Women, Suicide, and the Jury in Later Medieval England." Signs 32, no. 1 (2006), 141-166.

. "A Case of Indifference: Child Murder in Later Medieval England." Journal of Women's History 19, no. 4 (2007): 59-82.

."Cultures of Suicide?: Suicide Verdicts and the "Community" in Thirteenth- and Fourteenth-Century England." The Historian 69, no. 3 (2007): 427-449.

.Forensic Medicine and Death Investigation in England. New York: Routledge, 2015.

Caciola, Nancy. Afterlives: The Return of the Dead in the Middle Ages. Ithaca: Cornell 
University Press, 2016.

Cadden, Joan. Meaning of Sex Differences in the Middle Ages: Medicine, Science, and Culture. Cambridge: Cambridge University Press, 1993.

Craig, Ann Leigh. Wandering Women and Holy Matrons: Women as Pilgrims in the Later Middle Ages. Studies in Medieval and Reformation Traditions. Leiden: Brill, 2009.

Crawford, Sally. Childhood in Anglo-Saxon England. Stroud: Sutton Publishing, 1999. . "Children, death and the afterlife in Anglo-Saxon England." In The Archaeology of Anglo-Saxon England: Basic Readings in Anglo-Saxon England, edited by Catherine Karkov. New York: Garland Publishing, 1999.

Cressy, David. Birth, Marriage and Death: Ritual, Religion, and the Life-Cycle in Tudor and Stuart England. Oxford: Oxford University Press, 1997.

Daniell, Christopher. Death and Burial in Medieval England, 1066-1550. London: Routledge, 1997.

DeWitte, Sharon. "Age Patterns During the Black Death in London, A.D. 1349-1350." Journal of Archaeological Science 37, no. 12 (December 2010): 339-340.

Didron, Afne. "La Vie Humaine.” Annales archéologiques 15 (1855): 241-448.

Ebersole, Gary. "The Function of Ritual Weeping Revisited: Affective Expression and Moral Discourse." History of Religions 39, no. 3 (February 2000): 211-246.

Elias, Norbert. The History of Manners and State Formation. Translated by Edmund Jephcott. Vol. 1 of The Civilizing Process. Oxford: Blackwell Publishers, 1994.

Enders, Jody. Death by Drama and Other Medieval Urban Legends. Chicago: The University of Chicago Press, 2002.

Finucane, Ronald. Miracles and Pilgrims: Popular Beliefs in Medieval England. Totowa: Rowman and Littlefield, 1977.

The Rescue of the Innocents: Endangered Children in Medieval Miracles. New York: St. Martin's Press, 1997.

Flint, Valerie. "The Saint and the Operation of the Law: Reflections upon the Miracles of St. Thomas Cantilupe." In Belief and Culture in the Middle Ages: Studies Presented to Henry Mayr-Harting. Edited by Richard Gameson and Henrietta Leyser. Oxford: Oxford University Press, 2001. 
Frenken, Ralph. "The Psychology and History of Swaddling: Antiquity Until $15^{\text {th }}$ Century." The Journal of Psychohistory 39, no. 2 (2011): 84-114.

French, Katherine. The Good Women of the Parish: Gender and Religion after the Black Death. Philadelphia: University of Pennsylvania Press, 2008.

French, Katherine et al. The Ties That Bind: Essays in Medieval British History in Honor of Barbara Hanawalt. New York: Routledge, 2011.

Fryde, Frederick et al., Handbook of British Chronology, $3^{\text {rd }}$ edition. London: Royal Historical Society, 1986.

Geary, Patrick. Living with the Dead in the Middle Ages. Ithaca: Cornell University Press, 1994.

Gilchrist, Roberta, and Barney Sloane. Requiem: The Medieval Monastic Cemetery in Britain. London: Museum of London Archaeology Service, 2005.

Gilchrist, Roberta. Medieval Life: Archaeology and the Life Course. Woodbridge: The Boydell Press, 2012.

Gittings, Clare, and Peter Jupp, eds. Death in England: An Illustrated History. Manchester: Manchester University Press, 1999.

Gittings, Clare. Brasses and Brass Rubbing. London: Blandford Press, 1970.

Given, James. Society and Homicide in Thirteenth-Century England. Stanford: Stanford University Press, 1977.

Goldberg, Jeremy, and Felicity Riddy, eds. Youth in the Middle Ages. Woodbridge: Boydell Press, 2004.

Goldberg, Jeremy. "Life and death: the ages of man." In A Social History of England 1200-1500. Edited by Rosemary Horrox and William Ormrod. Cambridge: Cambridge University Press, 2006).

Goldberg, Jeremy, and Maryanne Kowaleski, eds. Medieval Domesticity: Home, Housing and Household in Medieval England. Cambridge: Cambridge University Press, 2008.

Goodich, Michael. Violence and Miracle in the Fourteenth Century: Private Grief and Public Salvation. Chicago: The University of Chicago Press, 1995.

Goodland, Katherine. Female Mourning in Medieval Renaissance English Drama: From the Raising of Lazarus to King Lear. Hampshire: Ashgate Publishing Limited, 2005. 
Gordon, Eleanora. "Accidents among Medieval Children as Seen from the Miracles of Six English Saints and Martyrs.” Medical History 35, no. 2 (1991): 145-163.

Green, Monica. “Women's Medical Practice and Health Care in Medieval Europe.” Signs 13, no. 2 (1989): 434-473.

The Trotula: An English Translation of the Medieval Compendium of Women's Medicine. Philadelphia: University of Pennsylvania Press, 2002.

Making Women's Medicine Masculine: The Rise of Male Authority in Pre-Modern Gynaecology. Oxford: Oxford University Press, 2008.

. "Caring for Gendered Bodies." In The Oxford Handbook of Women and Gender in Medieval Europe, edited by Judith Bennett and Ruth Karras, 345-361. Oxford: Oxford University Press, 2013.

Gwara, Joseph, and Mary Morse. "A Birth Girdle Printed by Wynkyn de Worde.” The Library: The Transactions of the Bibliographical Society 13, no. 1 (2012): 33-62.

Halliday, William. "Wayside Graves and Crossroad Burials.” Proceedings of the Cambridge Archaeological Society 84 (1995): 113-119.

Hanawalt, Barbara. "The Peasant Family and Crime in Fourteenth-Century England." Journal of British Studies 13, no. 2 (May 1974): 1-18.

. "Childrearing among the Lower Classes of Late Medieval England." The Journal of Interdisciplinary History 8, no. 1 (1977): 1-22.

The Ties that Bound: Peasant Families in Medieval England. Oxford: Oxford University Press, 1986.

. Growing Up in Medieval London: The Experience of Childhood in History. New York: Oxford University Press, 1993.

. "Medievalists and the Study of Childhood." Speculum 77, no. 2 (2001): 440-460.

Hanegbi, Cohen Naama. Caring for the Living Soul: Emotions, Medicine and Penance in the Late Medieval Mediterranean. The Medieval Mediterranean. Leiden: Brill, 2017.

Hansen, Anna. "Children and Their Foster-Parents in Early Icelandic Society." In Emotions in the Household, 1200-1900. Edited by Susan Broomhall. Houndmills: Palgrave Macmillan, 2008). 
Helmholz, Richard. "And were there children's rights in early modern England? The Canon Law and 'intra-family violence' in England, 1400-1640." The International Journal of Children's Rights 23, no.1 (1993): 23-32.

Herlihy, David. Medieval Households. Cambridge: Harvard University Press, 1985.

Houlbrooke, Ralph. Death, Religion, and the Family in England, 1480-1750. Oxford: Oxford University Press, 1998.

Huizinga, Johan. The Autumn of the Middle Ages. Translated by Rodney Payton and Ulrich Mammitzsch. Chicago: The University of Chicago Press, 1996.

Hunnisett, Roy. The Medieval Coroner. Cambridge: Cambridge University Press, 1961.

Jaeger, Stephen. The Origins of Courtliness: Civilizing Trends and the Formation of Courtly Ideals. Philadelphia: University of Pennsylvania Press, 1985.

Jordan, Alyce. "The Water of Thomas Becket: Water as a Medium, Metaphor, and Relic.” In The Nature and Function of Water, Baths, Bathing, and Hygiene from Antiquity through the Renaissance. Edited by Cynthia Kosso and Anne Scott, 479-500. Vol. 11 of Technology and Change in History. Leiden: Hotei Publishing, 2009.

Keen, Elizabeth. The Journey of a Book: Bartholomew the Englishman and the Properties of Things. Canberra: ANU E Press, 2007.

King, Margaret. "Concepts of Childhood: What We Know and Where We Might Go." Renaissance Quarterly 60, no. 2 (2007): 371-407.

Koopmans, Rachel. Wonderful to Relate: Miracle Stories and Miracle Collecting in High Medieval England. Philadelphia: University of Pennsylvania Press, 2011.

Krause, John. “The Medieval Household: Large or Small?” The Economic History Review 9, no. 3 (1957): 420-432.

Laes, Christian, and Katariina Mustakallio, eds. The Dark Side of Childhood in Late Antiquity and the Middle Ages. Oxford: Oxbow Books, 2011.

Lansing, Passion and Order: Restraint of Grief in the Medieval Italian Communes. Ithaca: Cornell University Press, 2008.

Leyser, Conrad, and Leslie Smith, eds., Motherhood, Religion, and Society in Medieval Europe, 400-1400: Essays Presented to Henrietta Leyser. London: Routledge, 2011.

Maddicott, John. Simon de Montfort. Cambridge: Cambridge University Press, 1994. 
Moss, Rachel. Fatherhood and its Representations in Middle English Texts. Cambridge: D.S. Brewer, 2013.

Murray, Alexander. Suicide in the Middle Ages: The Violent Against Themselves. Vol. 1 of Suicide in the Middle Ages. Oxford: Oxford University Press, 1996.

Newman, Paul. Growing Up in the Middle Ages. London: McFarland \& Company INC., 2007.

Orme, Nicholas. “The Culture of Children in Medieval England.” Past and Present 148, no. 1 (1995): 48-88.

Medieval Children. New Haven: Yale University Press, 2001.

. Fleas, Flies, and Friars: Children's Poetry from the Middle Ages. Ithaca: Cornell University Press, 2011.

Oosterwijk, Sophie. "Chrysoms, Shrouds and Infants on English Tomb Monuments: A Question of Terminology?." Church Monuments 15 (2000): 44-64.

Parson, John. "The Year of Eleanor of Castile's Birth and her Children by Edward I." Medieval Studies 46, no. 1 (1984): 245-265.

Patton, Kimberley, and John Hawley, eds., Holy Tears: Weeping in the Religious Imagination. Princeton: Princeton University Press, 2005.

Phillips, Page-John. Children on Brasses. London: George Allen and Unwin LTD, 1970.

Piroyansky, Danna. Martyrs in the Making: Political Martyrdom in Late Medieval England. Houndmills: Palgrave, 2008.

Pollock, Linda. Forgotten Children. Cambridge: Cambridge University Press, 1983.

Power, Elleen. Medieval English Nunneries. Cambridge: Cambrige University Press, 2010.

Rawcliffe, Carole. "Women, Childbirth, and Religion in Medieval England." In Women and Religion in Medieval England. Edited by Diana Wood. Oxford: Oxbow Books, 2003.

Razi, Zvi. Life, Marriage, and Death in a Medieval Parish: Economy Society and Demography in Halesowen 1270-1400. New York: Cambridge University Press, 1980 . 
England." Past and Present 93, no. 1 (1981): 3-36.

Roberts, Brian. Rural Settlements in Britain. Studies in Historical Geography. Kent: Dawson \& Sons, 1977.

Robertson, Elizabeth. Early English Devotional Prose and the Female Audience. Knoxville: The University of Tenessee Press, 1990.

Rosenwein, Barbara. "Worrying about Emotions in History." The American Historical Review 107, no. 3 (2002): 821-845.

. Emotional Communities in the Early Middle Ages. New York: Cornell University Press, 2006.

Generations of Feeling: A History of Emotions, 600-1700. Cambridge: Cambridge University Press, 2016.

Rowland, Beryl. "Classical and Medieval Ideas on the "Ages of Man" and the Middle English Poem "The Parlement of the Thre Ages." Poetica 3 (1975): 17-29.

Schaus, Margaret, ed. Women and Gender in Medieval Europe: An Encyclopedia. New York: Routledge, 2006.

Schofield, Richard, and Edward Wrigley. The Population History of England, 15411871: A Reconstruction. Cambridge: Cambridge University Press, 1981,1989.

Schmitt, Claude-Jean. Ghosts in the Middle Ages: The Living and the Dead in Medieval Society. Translated by Teresa Lavender Fagan. Chicago: The University of Chicago Press, 1998.

Shahar, Shulamith. Childhood in the Middle Ages. London: Routledge, 1990.

Singman, Jeffrey. Daily Life in Elizabethan England. Westport. Greenwood Press, 1995. . Daily Life in Medieval Europe. Westport: Greenwood Press, 1999.

Sloane, Barney. The Black Death in London. Stroud: The History Press, 2011.

Smith, Kathryn. "The Neville Hornby Hours and the Design of Literate Devotion." The Art Bulletin 81, no. 1 (1999), 72-92.

Staley, Lynn. "Pearl and the Contingencies of Love and Piety." In Medieval Literature and Historical Inquiry: Essays in Honor of Derek Pearsall. Edited by Derek Ares. Woodbridge: Boydell \& Brewer LTD, 2000.

Stoertz-Harris, Fionna. "Pregnancy and Childbirth in Twelfth- and Thirteenth-Century 
French and English Law." Journal of the History of Sexuality 21, no. 2 (May 2012): 263-281.

Squires, Kirsty. "Through the Flames of the Pyre: The Continuing Search for AngloSaxon Infants and Children.” In Medieval Childhood: Archaeological Approaches. Edited by Dawn Hadley and Katie Hemer. Oxford: Oxbow Books, 2014.

Stone, Lawrence. The Family, Sex and Marriage in England, 1500-1800. New York: Harper and Row Publishers, Inc., 1977.

Sumption, Jonathan. Pilgrimage: An Image of Medieval Religion. Totowa: Rowan and Littlefield, 1975.

Tomaini, Thea, ed. Dealing with the Dead: Mortality and Community in Medieval and Early Modern Europe. Vol. 5 of Explorations in Medieval Culture. Leiden: Brill, 2018.

Vines, Amy. "Lullaby as Lament: Learning to Mourn in Middle English Nativity Lyrics." In Laments for the Lost in Medieval Literature, Edited by Jane Tolmie and Jane Toswell. Turnhout: Brepolis, 2010.

Williams, Howard. "Death, Memory, and Time." In Time in the Medieval World. Edited by Chris Humphrey and William Ormrod. Woodbridge: York Medieval Press, 2001.

Woogler, Chris. The Great Household in Late Medieval England. New Haven: Yale University Press, 1999.

Woolf, Rosemary. The English Religious Lyric in the Middle Ages. Oxford: Clarendon Press, 1986.

Art and Doctrine: Essays on Medieval Literature, edited by Heather O’Donoghue. London: The Hambledon Press, 1986.

Ziollowski, Jan. "Laments for Lost Children: Latin Traditions." In Laments for the Lost in Medieval Literature, edited by Jane Tolmie and Jane Toswell, 81-108. Turnhout: Brepolis, 2010. 


\section{VITA}

Danielle Griego was born and raised in New Mexico. She received a BA in Anthropology/Archaeology at the University of New Mexico and went on to pursue an MPhil in Medieval History at the University of Cambridge. For both of her degrees, she focused on descriptions of death in Anglo-Saxon England. Griego went on to pursue her doctoral degree at the University of Missouri-Columbia. While there, she focused on medieval descriptions of suicide and homicide, as well as accounts of child death in coroners' records, lullabies, and miracle stories. 